UNIVERSIDADE DE SÃO PAULO

FACULDADE DE FILOSOFIA, CIÊNCIAS E LETRAS DE RIBEIRÃO PRETO PROGRAMA DE PÓS-GRADUAÇÃO EM EDUCAÇÃO

\title{
ARGUMENTAÇÃO EM DISSERTAÇÕES DO ENSINO MÉDIO: \\ COTAS RACIAIS EM DISCURSO
}

DAYANE PEREIRA BATISTA

RIBEIRÃO PRETO - SP

2016 
DAYANE PEREIRA BATISTA

\section{ARGUMENTAÇÃO EM DISSERTAÇÕES DO ENSINO MÉDIO: COTAS RACIAIS EM DISCURSO}

Dissertação apresentada à Faculdade de Filosofia, Ciências e Letras de Ribeirão Preto da USP, como parte das exigências para a obtenção do título de Mestre em Ciências, Área: Educação.

(Versão corrigida)

Orientadora: Prof. ${ }^{a}$ Dr. ${ }^{a}$ Soraya Maria Romano Pacífico

RIBEIRÃO PRETO - SP 
Autorizo a reprodução e divulgação total ou parcial deste trabalho, por qualquer meio convencional ou eletrônico, para fins de estudo e pesquisa, desde que citada a fonte.

Batista, Dayane Pereira

Argumentação em dissertações do Ensino Médio: Cotas raciais em discurso. Ribeirão Preto, 2016. 102 p.: il.; $30 \mathrm{~cm}$

Dissertação de Mestrado apresentada à Faculdade de Filosofia, Ciências e Letras de Ribeirão Preto/USP. Área de concentração: Educação.

Orientadora: Pacífico, Soraya Maria Romano. 
Nome: BATISTA, Dayane Pereira

Título: Argumentação em dissertações do Ensino Médio: Cotas raciais em discurso

Dissertação apresentada à Faculdade de Filosofia, Ciências e Letras de Ribeirão Preto da USP, como parte das exigências para a obtenção do título de Mestre em Ciências, Área: Educação.

Aprovado em:

Banca Examinadora

Prof. Dr.

Instituição:

Julgamento:

Assinatura:

Prof. Dr.

Instituição:

Julgamento:

Assinatura:

Prof. Dr.

Instituição:

Julgamento:

Assinatura: 
Dedico este trabalho a Alice e Soraya, mulheres fortes e doces que iluminam maravilhosamente a minha vida. 


\section{AGRADECIMENTOS}

Até aqui nos ajudou o Senhor.

(1 Samuel 7:12)

Agradeço:

À minha querida professora e orientadora Soraya por ter iluminado o meu caminho acadêmico e pessoal.

À banca composta pelos professores Lucília Maria Abraão e Sousa e Roberto Leiser Baronas. Obrigada por todas as críticas, provocações, elogios, indagações e por reconhecem a importância dessa pesquisa.

À família Batista por todo o apoio durante minha vida pessoal, profissional e acadêmica: Wilson, Wilson Jr., Mariana, Pedro, Pablo, Mônica, Mosiah, Filipi, Miguel, Ester e especialmente a minha mãe, Alice, por suportar minhas inconstâncias e me motivar a vencer todas as lutas.

À Juliana Caseiro Viviani, pelo incentivo e dedicação constantes.

Às minhas amigas e também orientandas da professora Soraya. Especialmente, Aparecida Pin, por estar ao meu lado nessa jornada.

À Danival Samuel (ex-professor de geografia), a Patrícia Macedo e a Thaís Marinheiro por me mostrarem que a escola está aberta para a sociedade.

À Vagner Barcelos, por me apresentar sentidos silenciados e espaços anteriormente distantes e inatingíveis.

Aos meus ex-alunos, pelo carinho e valorização do meu trabalho.

Aos membros das instituições escolares nas quais eu trabalhei por valorizarem a minha dedicação ao ensino escolar. Especialmente, a ONG FONTE - Araraquara (Frente Organizada para Temática Étnica), ao colégio Liceu Contemporâneo e ao CAPE (Centro Popular de Apoio Estudantil).

À Sylvia Telarolli, por me orientar no estágio departamental.

À Alessandra Del Ré, por ter sido minha orientadora e me apoiar concretamente na realização do meu intercâmbio para os Estados Unidos.

Às participantes do GEALin-Grupo de Estudos em Aquisição de Linguagem (FCLAr-UNESP) coordenado pela professora Alessandra Del Ré.

Aos docentes, discentes e funcionários da UNESP - Araraquara por serem minha família durante a curso de graduação, especialmente as amigas Ana Carolina Cangemi, Thaís Abreu e Gisela Fávaro. 
Aos professores Débora Cristina Piotto e Márcio Mucedula Aguiar por viabilizarem a discussão sobre a temática racial e social na USP de Ribeirão Preto por meio da disciplina "Ensino Superior, Inclusão e Diversidade Étnica-Racial".

À USP Ribeirão Preto por ter me acolhido. Em especial, aos membros do El@dis e do grupo de estudos Discurso e Memória: nos movimentos do sujeito.

À CAPES pela concessão da bolsa de mestrado e pelo apoio financeiro para a realização desta pesquisa. 
Há certamente um "ponto de nãoretorno", mas, para não voltar atrás, é preciso avançar, e, para avançar, quantas dificuldades e lutas! (ALTHUSSER, 1978, p. 46). 


\section{RESUMO}

BATISTA, D. P. Argumentação em dissertações do ensino médio: cotas raciais em discurso. 2016. 102f. Dissertação (Mestrado) - Faculdade de Filosofia, Ciências e Letras de Ribeirão Preto. Universidade de São Paulo. Ribeirão Preto, São Paulo, 2016.

Em 29 de agosto de 2012, foi implementada no Brasil a Lei $\mathrm{n}^{\circ} 12.711$ que viabiliza a reserva de vagas para afrodescendentes em cursos de graduação, em universidades federais. Isso potencializou diversas discussões e suscitou posicionamentos de aceitação ou de rejeição às chamadas cotas raciais. Essa política afirmativa reflete, diretamente, na configuração do ensino superior nacional; por isso, defendemos que ela deve ser problematizada, na instituição escolar, desde o Ensino Médio, uma vez que os alunos dessa etapa serão os mais afetados, pela lei, no que se refere ao vestibular. Embasados no dispositivo teórico-analítico da Análise do Discurso de linha francesa, formulada por Michel Pêcheux, dialogamos com quatro turmas do terceiro ano do Ensino Médio, de duas escolas da rede pública do Estado de São Paulo e, a partir da leitura de dois textos jornalísticos ("A reserva de vagas dá oportunidade aos menos favorecidos frequentarem instituições de qualidade", de Letícia Januário e "O grande erro das cotas", de Julia Carvalho) discutimos sobre "As cotas raciais em universidades públicas brasileiras". Posteriormente, solicitamos que os sujeitos-alunos escrevessem um texto dissertativoargumentativo sobre o tema e essa produção escrita constitui o corpus desta pesquisa. Com base nas análises, encontramos dissertações que se posicionam contrariamente às cotas, sustentando-se na afirmação do discurso jurídico, com sentidos parafrásticos, de que "todos são iguais perante a lei". Por outro lado, há textos que sustentam que as cotas são necessárias como meio de reparação social devido à escravização dos afrodescendentes. Os resultados apontam que o discurso dominante, em nosso corpus, reverbera sentidos legitimados sobre o passado histórico dos afrodescendentes, ou seja, sentidos que os discursivizam como inferiores e os sujeitos-alunos não apresentaram uma discussão acerca da constituição sócio-histórica da inferioridade atribuída a esse grupo. Isso indica que, pela força da memória discursiva e da ideologia, o afrodescendente ainda é discursivizado em relação à sua (in) capacidade intelectual.

Palavras-chave: Análise do Discurso. Argumentação. Cotas raciais. 


\begin{abstract}
BATISTA, D. P. Argumentation in high school dissertations: racial quotas in discourse. 2016. 102f. Master's dissertation - Faculdade de Filosofia, Ciências e Letras de Ribeirão Preto. Universidade de São Paulo. Ribeirão Preto, São Paulo, 2016.

On August 29, 2012 was implemented in Brazil law No. 12.711 which feasibility the reservation of vacancies for afro-descendants in undergraduate courses in federal universities. This enhanced several discussions and raised positionings of acceptance and rejection to so-called racial quotas. This affirmative policy reflects straight in the national higher education setting; for this reason, we argue that it should be problematized in educational institutions since high school, as the students of this stage will be most affected by the law because of vestibular (admittance exam). Grounded in the theoretical and analytical device of Discourse Analysis from French school, raised by Pêcheux, we dialogued with four classes of the third year of high school, in two public schools in the State of São Paulo and by the reading of two journalistic texts ("Reserve of vacancies gives opportunity for disadvantaged to attend high quality institutions", by Leticia Januário and "The big mistake of quotas", by Julia Carvalho) we discussed about "Racial quotas in Brazilian public universities". Later, we request the students to write argumentative dissertation texts about the theme, and this writing production is what constitutes the corpus of this research. Based on the analysis, we found dissertations that stand an opposite position to quotas, supporting themselves on the statement of legal discourse, with paraphrases of the meanings that "all are same before the law." On the other hand, there are texts sustaining that quotas are necessary as a means to social repair due to the slavery of afro-descendants. The results point that the dominant discourse in our corpus, reverberates legitimated meanings about the historical past of afro-descendants, in other words, meanings of a discourse about them as inferior beings, and the student subjects did not present a discussion about the social and historical constitution of this inferiority assigned to this group. This indicates that by the strength of discursive memory and ideology the afro-descendants are still in discursively with regard to their intellectual (in) capacity.
\end{abstract}

Keywords: Discourse Analysis . Argumentation. Racial quotas. 


\section{FIGURAS}

Figura 1 - Negro (Google) ........................................................................... 5

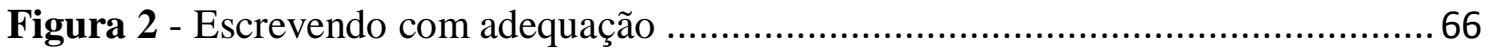




\section{Sumário}

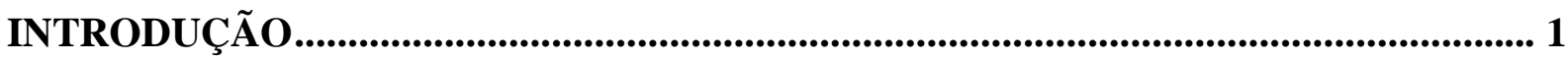

1. ANÁLISE DO DISCURSO E ARGUMENTAÇÃO ................................................... 10

2. O DISCURSO OFICIAL SOBRE AS COTAS RACIAIS ............................................. 30

2. 1 POLÍTICAS AFIRMATIVAS DE RECORTE RACIAL: UMA TEMÁTICA QUE RECLAMA ARGUMENTAÇÃO .............................................................................. 37

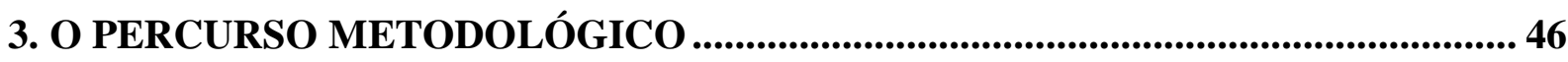

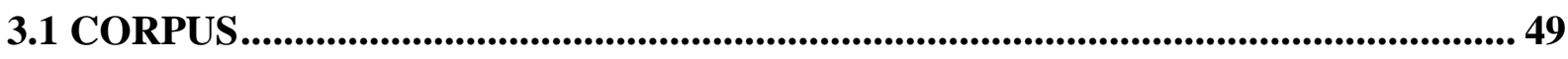

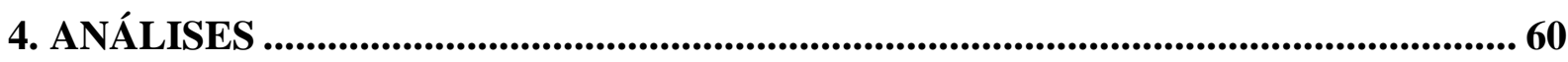

4. 1 TODOS, ELES E NÓS: A INCLUSÃO/EXCLUSÃO DO SUJEITO NA FD DO SER OU NÃO SER AFRODESCENDENTE.................................................................. 67

4.2 O DISCURSO SOBRE (IN) CAPACIDADE DOS AFRODESCENDENTES .......... 72

4.3 ARGUMENTOS FAVORÁVEIS ÀS COTAS …………............................................ 77

4.4 ARGUMENTOS DESFAVORÁVEIS ÀS COTAS................................................... 81

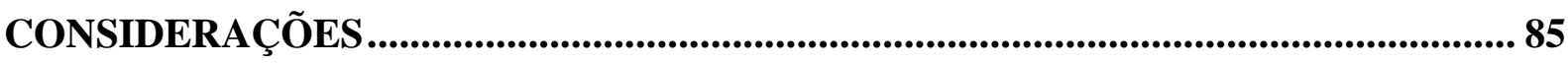

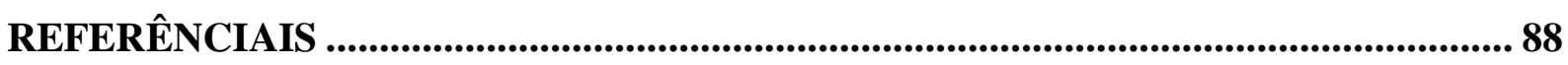

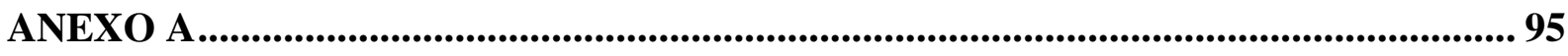

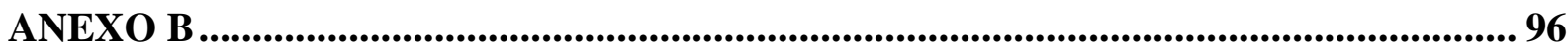

ANEXO C......................................................................................................... 98

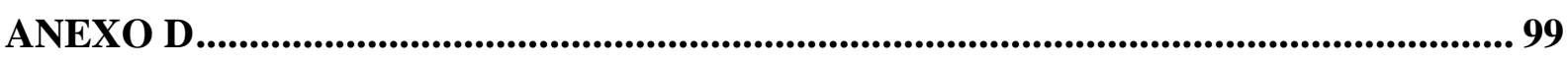

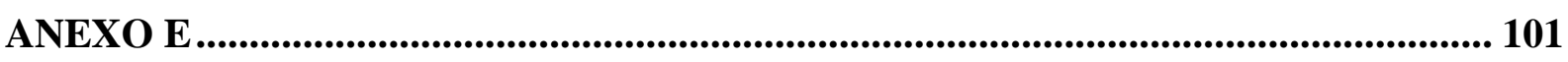

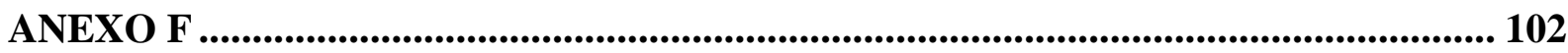




\section{INTRODUÇÃO}

Vem, vamos embora

Que esperar não é saber

Quem sabe faz a hora

Não espera acontecer

(VANDRÉ, 1968)

Compreender uma sociedade é algo complexo e devemos considerar diversas variáveis, dentre elas o funcionamento linguístico. Há estudos que entendem a língua como um sistema, ou um instrumento de comunicação ou como discurso. Neste trabalho, a perspectiva é a de discurso, ou seja, este trabalho está filiado à Análise do Discurso (doravante AD) de linha francesa, norteada por Pêcheux. Com efeito, concebemos a língua em sua discursividade, pois reconhecemos a importância da língua/linguagem para a constituição de uma sociedade e o texto como um espaço em que questões ideológicas e sociais podem ser manifestadas e/ou silenciadas.

Nosso escopo teórico defende que o discurso é "palavra em movimento, prática de linguagem: com o estudo do discurso observa-se o homem falando" (ORLANDI, 2001, p. 15) e analisar o discurso é uma tarefa que deve atentar-se para o movimento presente na prática da linguagem do sujeito, pois a $\mathrm{AD}$ compreende a língua fazendo sentido e, também, como trabalho simbólico, pois o discurso é um elemento constitutivo do homem e de sua história (ORLANDI, 2001), de modo que sempre valorizamos o sujeito, o discurso e a sua materialidade histórica:

Trabalhar com o discurso em $\mathrm{AD}$ consiste em investigar o processo de imbricamento da materialidade histórica com a materialidade linguística, buscando desfazer os efeitos provocados pelo próprio processo. Os efeitos de linearidade, univocidade, continuidade e transparência da língua e da história- do discurso, portanto, só podem ser desfeitos a partir de uma perspectiva que considere a exterioridade como constitutiva, isto é, que não busque separar o dentro/fora do discurso (SCHONS; MITTMANN, 2009, p. 295).

A AD considera a exterioridade que envolve os sentidos do discurso para fazer uma análise que não seja apenas estrutural, baseada, unicamente, em prescrições gramaticais, isso porque a língua não é unívoca e transparente e deve ser compreendida a partir da opacidade de sua materialidade linguística e histórica. 
A escola tem a função de normatizar o uso da língua por meio do ensino da gramática normativa e precisamos entender como ela executa esse papel. O livro de Alessandra Rodrigues (2011) "Escrita e Autoria: entre histórias, memórias e descobertas" teceu um panorama sobre a educação nacional vinculando-o às questões linguísticas e demonstra o poder das constituições, dos manuais de urbanidade e das gramáticas no processo de colonização do Brasil e, por conseguinte, na propagação e na afirmação da língua portuguesa em detrimento das línguas indígenas e africanas. Segundo a autora, "As línguas são fortes marcadores de poder social, e por isso, são importantes termômetros para avaliar tensões, mudanças, preconceitos e manipulações" (RODRIGUES, 2011, p.30). Para nós reconhecemos que é essencial estudar a língua por meio da interpretação de sua discursividade a fim de compreender traços que podem estar presentes em uma sociedade, como por exemplo, o preconceito e as manipulações.

Ao analisarmos as contribuições da AD para a instituição escolar, constatamos que a $\mathrm{AD}$ levou a 'um 'aperfeiçoamento' da concepção de língua e ao início de trabalhos e pesquisas sobre práticas discursivas e de letramento" (RODRIGUES, 2011, p. 40) e seus conceitos versam sobre a concepção de escrita como leitura e prática social, pois exige interações para a construção do sentido. A perspectiva discursiva ressalta as práticas de produção da escrita na escola para que o sujeito-aluno possa ir além do consumo de ideias e da aplicação de regras gramaticais, porque valoriza o caráter histórico-cultural da língua e do sujeito.

Eni Orlandi (2007), em "As formas do Silêncio no movimento dos sentidos", apresenta seus estudos sobre os sentidos do silêncio e reflexões sobre o dizível e o indizível: "Pensada através da noção de silêncio, [...] a própria noção de censura se alarga para compreender qualquer processo de silenciamento que limite o sujeito no percurso do sentido" (ORLANDI, 2007, p. 13). Sustentamos que o silêncio também significa e o processo de silenciamento está atrelado a algo que limita o sujeito no movimento de compreensão do sentido que sempre pode ser outro.

É possível vincular o silêncio nas palavras à marginalização que ocorreu com os africanos no Brasil, pois frações de sua cultura, de suas línguas, religiões e costumes foram, e ainda são desprestigiados socialmente; todavia, reconhecemos que os sujeitos e os sentidos podem encontrar brechas e significar de outros modos, de tal forma que a cultura afro conseguiu contribuir para a constituição desse país em diversos aspectos. Constatamos que o preconceito racial e a inferiorização dos afrodescendentes esteve presente a partir do momento em que os africanos, oriundos de diversos países, foram 
trazidos ao Brasil e obrigados a exercer trabalho escravo. Posteriormente, em 13 de maio de 1888, houve a abolição da escravatura, porém esse grupo étnico, em sua maioria, não encontrou concretas condições de inserção na sociedade. Visto que nosso estudo está relacionado a questões sócio-históricas e somos filiados a AD pecheutiana, faz-se necessário problematizamos a questão da nomeação destinada aos afrodescendentes que utilizaremos aqui.

Acerca da questão da nomeação racial, a entrevista do site Scielo Brasil intitulada "A difícil tarefa de definir quem é negro no Brasil" com o antropólogo de Kabengele Munanga, professor-titular da Faculdade de Filosofia, Letras e Ciências Humanas da USP pondera sobre questões relacionadas às cotas raciais e o professor assegura que não é fácil definir quem é negro no Brasil, pois o país se desenvolveu com o desejo de branqueamento. Vale ressaltar existência da incompletude na linguagem e que a escolha de uma nomeação não é neutra e que existiram ações que visavam ao branqueamento do país, especialmente no século XIX, e, consequentemente, ainda há uma dificuldade de um sujeito se reconhecer e se assumir como afrodescendente em um recenseamento demográfico baseado na autodeclaração racial.

De acordo com Rocha e Rosemberg (2008) a cor da pele foi introduzida como critério fundamental para diferenciar as chamadas raças humanas no século XVIII na Europa Ocidental. Esse fato pode estar relacionado à hierarquização e ao preconceito social baseados em aspectos étnicos por meio de uma classificação racial. O IBGE (Instituto Brasileiro de Geografia e Estatística), responsável pelo recenseamento demográfico, utiliza uma nomenclatura que solicita que o cidadão se declare como branco, preto, pardo, indígena ou amarelo. Diante disso, questionamos: o que representaria a denominação "pretos" e "pardos"? Essas palavras estão vinculadas a elementos presentes na constituição histórica brasileira:

O vocabulário racial assentado em "cor de pele" penetrou o Brasil Colônia e se mantém até os dias atuais, sendo as mesmas alternativas de cor incluídas nos inquéritos populacionais, com pequenas variações, desde o primeiro Censo Demográfico de 1872. Isso não significa, porém, que o mesmo termo, por exemplo, branco ou preto, evoque os mesmos sentidos nos diferentes contextos sociais e históricos em que têm sido empregados para diferencias grupos humanos. (ROCHA, ROSEMBERG, 2008, p. 763). 
A pesquisa realizada pelo primeiro Censo Demográfico realizado no Brasil, em 1872, já possuía questões vinculadas à denominação de etnias e apresentava as opções: branco, preto, pardo e caboclo. As palavras têm memória elas não nascem no momento da enunciação e nós nos constituímos como sujeitos da linguagem por meio da enunciação, pois "todo texto é construído a partir de um já-dito (interdiscurso) e isso reclama do leitor uma memória do dizer, que não é uma memória psicológica, mas sim, uma memória sócio-histórica e, portanto, discursiva." (PACÍFICO, 2002, p. 15). A questão da escolha dos termos não é neutra visto que as palavras podem ter sentidos distintos dependendo dos contextos sociais e de aspectos históricos, ou seja, elas podem ter significados diferentes dependendo das formações ideológicas e discursivas nas quais o sujeito histórico e social está inserido, de modo que o termo "preto" utilizado pelo IBGE pode evocar sentidos relacionados ao preconceito racial imbricado na história brasileira e como resultado, optamos por não utilizar essa palavra em nossa pesquisa.

Precisamos compreender quais os efeitos de sentidos possíveis ao se escolher uma palavra para a nomeação étnica, não apenas nas bibliografias acadêmicas, mas, também, por meio do acesso às informações contidas na internet. Na contemporaneidade, tal rede se mostra como essencial para a proliferação de dados. $\mathrm{O}$ termo "negro" é mais aceito para retratar esse grupo, e isso pode ser comprovado por meio da denominação "Movimento Negro" (grupos que promovem diversas atividades com o intuito de conquistar os direitos dos afrodescendentes). Todavia, ao fazermos uma busca no Google, banco de dados abrangente que "passa a ser ícone de suposta completude no tocante ao saber" (FARIA, 2016, p. 30), percebemos quais acepções são atribuídas à "negro": 
Figura 1 - Negro (Google)

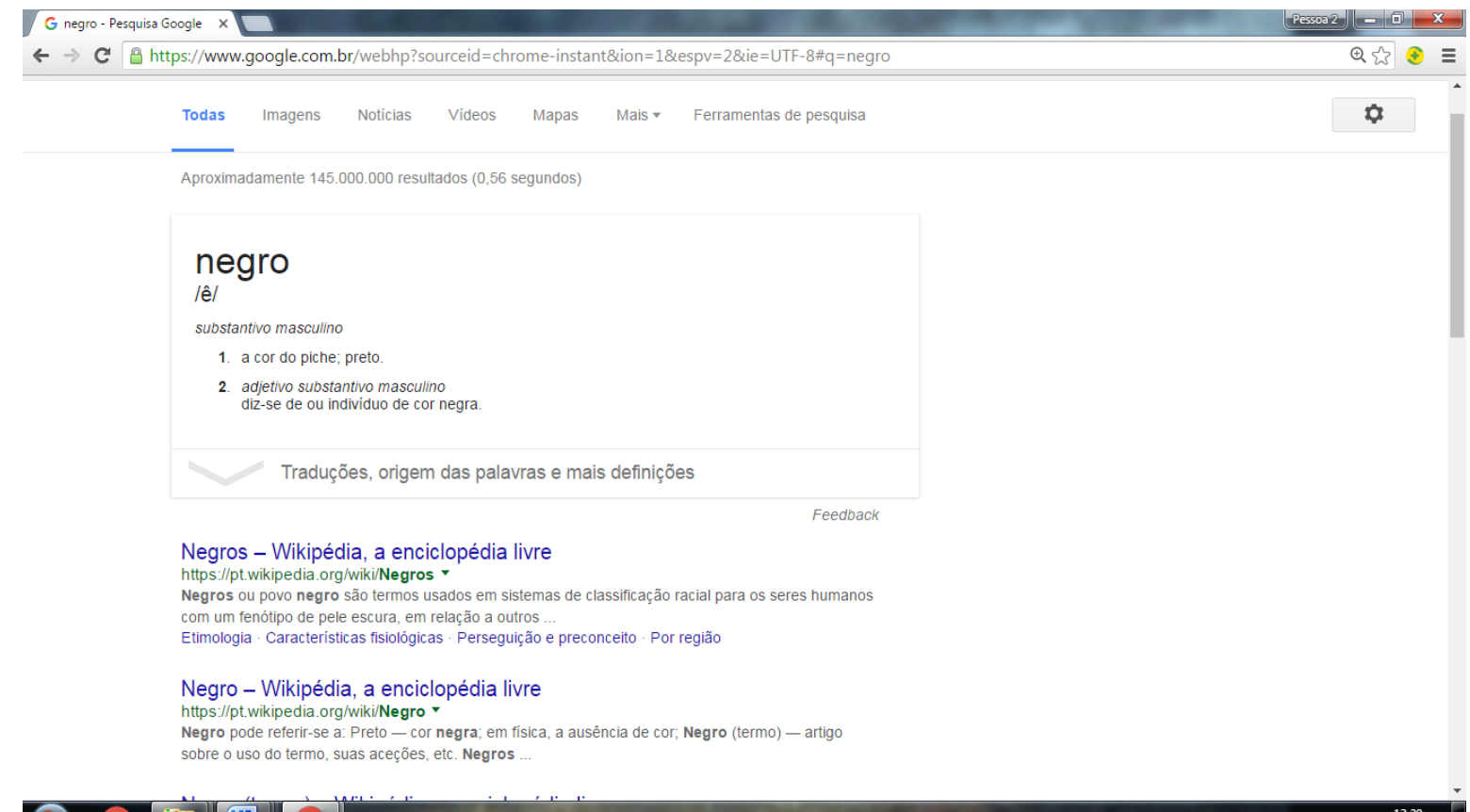

(4) 9 茴

Fonte: Elaboração própria.

No Google, a primeira acepção de "negro" é substantivo masculino "a cor do piche" e em seguida "preto" e apenas a segunda acepção faz referência à denominação de um grupo étnico: adjetivo substantivo masculino "diz-se de ou indivíduo de cor negra" e de acordo com essa ferramenta de busca, "negro" é sinônimo "preto". Estranhamos esses sentidos que circulam na internet, uma vez que atribuem ao afrodescendente a cor de piche e reiteram alusões preconceituosas. Essas definições corroboram o fato de que "ocorre uma valorização positiva da cor branca (metáfora de divindade, da pureza, e da luz) e uma valorização negativa da cor negra (a treva, o satã, o pecado)" (ROCHA, ROSEMBERG, 2008, p. 764), em outras palavras, verificamos que o termo "negro" está relacionado a "contextos de explicitação de discriminação e preconceito." (ROCHA, ROSEMBERG, 2008, p. 766), ou seja, o termo “negro" está também atrelado a sentidos pejorativos.

Com base nessas considerações e sabendo que uma escolha lexical silencia outras, optamos, neste trabalho, pelo uso da nomeação "afrodescendente", pois ela evoca sentidos vinculados à ancestralidade africana mesmo sabendo que esse continente foi explorado e parte de sua população foi dissipada e escravizada, especialmente nas Américas. Fizemos essa escolha porque defendemos que a partir do reconhecimento desses fatos históricos é possível lutar para melhorar avida desse e de outros grupos 
marginalizados. Ademais, principalmente, por nos filiarmos a uma teoria que valoriza a constituição sócio-histórica dos sentidos, entendemos que nossa opção pelo uso de afrodescendente justifica-se por sua tessitura histórica dos sentidos de luta vivida por um povo que até hoje, século XXI, precisa batalhar para mostrar que é merecedor de seu lugar social. O lugar, a língua, a religião, os costumes dos povos afrodescendentes thes foram tirados, portanto, é preciso desnaturalizar os sentidos de que o afrodescendente é inferior para que assim eles possam assumir posições prestigiadas socialmente, posições essas que podem ser possibilitadas por meio do ensino formal da instituição escolar.

As teorias educacionais não críticas apresentadas por Saviani (1999) pensam a educação como instrumento de equalização social para a superação da marginalidade, pois ela, teoricamente, proporcionaria a integração dos membros segregados e a correção de distorções. Desse modo, a educação formal, representada pela instituição escolar, poderia, então, alterar a realidade profissional e econômica atual dos afrodescendentes, por exemplo, oferecendo-lhes melhorias nas condições socioeconômicas.

Com essa perspectiva, na qual a educação poderia facilitar a vida dos sujeitos na sociedade, o Governo Federal instaurou algumas medidas vinculadas ao ingresso e à permanência de estudantes oriundos de escolas públicas em universidades particulares. O MEC (Ministério da Educação e Cultura) apresenta o Programa Universidade para Todos (ProUni), criado em 2004 pela Lei n ${ }^{\circ}$ 11.096/2005, que visa a conceder bolsas de estudos integrais e parciais a estudantes de cursos de graduação e de cursos sequenciais de formação específica, em instituições privadas de educação superior. O Governo Federal entende a Educação Superior como elemento primordial para a mobilidade social, de modo que esse programa possibilitou a entrada de milhares de alunos em universidades particulares. Notamos, então, que as políticas públicas podem influenciar ou determinar o panorama educacional, de tal maneira que a compreensão do discurso político é relevante para entendermos questões primordiais acerca da educação, pois acreditamos que "No quadro da análise do discurso, essa questão mais aguda no escopo do discurso político, é, no entanto, passível de ser tratada no âmbito da linguagem em geral. E isso pela sua inserção no domínio da relação pensamento/linguagem/mundo" (ORLANDI, 2007, p. 94). Para compreendermos a questão ressaltada, é necessário estudarmos, também, o discurso político presente nas leis direcionadas à educação e esse é um dos objetivos de nosso estudo. 
A SEPPIR (Secretaria de Políticas de Promoção da Igualdade Racial), propiciadora da articulação de projetos institucionais voltados para os direitos culturais, econômicos e sociais da população afrodescendente brasileira, contribuiu para a política de cotas nas universidades destinadas a pessoas que se autodeclaram pretos ou pardos. Como resultado de sua atuação e luta foi sancionada a Lei n ${ }^{\circ} 12.711$, de 29 de agosto de 2012, que institui reserva de 50\% das vagas das universidades federais para estudantes oriundos do Ensino Médio público, com recorte racial e de renda, denotando a maximização dessas políticas de equalização e seus efeitos públicos.

Ao nos preocuparmos com o discurso jurídico notamos que por meio dele é possível aparentar uma determinação que na verdade remete ao indeterminado. Um exemplo pode ser constatado em conceitos que simulam uma noção de totalidade, muitas vezes irreal, e "constata-se, de modo característico, que esse fenômeno da indeterminação (ou de não saturação) se encontra tanto no discurso do aparelho jurídico ('Aquele que causar algum prejuízo para alguém deverá repará-lo’) como no funcionamento 'cotidiano' das noções gerais [...] e finalmente, no funcionamento (científico) do conceito." (PÊCHEUX, 1988, p. 97-98). De acordo com essas postulações é possível trazer a afirmação de Frege (1978, p. 79): “É por meio dessa indefinição que o sentido adquire a generalidade que se espera de uma lei” e Pêcheux (1988) defende que no aparelho jurídico há uma simulação constitutiva entre os operadores jurídicos e os mecanismos de dedução conceptual, e essa relação é confirmada pelo funcionamento aparentemente homogêneo do discurso. Todavia, duvidamos da homogeneidade do discurso, pois entendemos que o discurso é o lugar da contradição.

Claudine Haroche (1992) pondera que no século XVIII houve a ascensão do poder do jurídico (em detrimento dos valores religiosos) e da ideia de um sujeito livre e proprietário. Entretanto, essa conjuntura, apesar de propagar uma suposta liberdade, visava a propiciar o amor e o dever do sujeito em direção ao Estado e estabelecer um novo modo de assujeitamento. Assim, o dito popular "Lei não se discute, lei se cumpre" é proferido frequentemente, e, talvez, essa recorrência justifique a circulação desse dizer ainda, na contemporaneidade. Contudo, questionamos: a escola deve de fato aceitar as cotas raciais sem discussão, compreensão e reflexão ou a escola pode (e deve) problematizar o assunto e realmente inserir a temática racial em seu cotidiano? Segundo Lopes (2003), “a implantação de políticas de ação afirmativa deve ser acompanhada por uma ampla discussão", ou seja, é fundamental propiciar mais espaços de discussão 
sobre a lei que implementa as cotas raciais. Entretanto, há dúvidas sobre se a discussão chega à sala de aula com a verificação das vozes, opiniões e argumentos dos professores e, especialmente, dos sujeitos-alunos e um dos textos que valorizam a disputa pelos sentidos é a dissertação-argumentativa que é elementar para repercutir questões sociais tangenciais ao cotidiano do sujeito-aluno. Assim, nosso estudo visa a compreender como/se o sujeito-aluno argumenta sobre as cotas raciais em universidades públicas brasileiras por meio da escrita de um texto dissertativo-argumentativo.

A argumentação não deve ser vista de modo segmentado apenas como um dos componentes do currículo escolar, especialmente, vinculado à disciplina de Língua Portuguesa, visto que "os discursos são sempre o espaço privilegiado de luta entre vozes sociais, o que significa que são precipuamente o lugar da contradição, ou seja, da argumentação" (FIORIN, 2015, p. 9). Fiorin (2015) aponta que os discursos representam o lugar para a contradição e para a argumentação.

Possivelmente, as universidades públicas (consideradas como melhores do que as privadas) concordam com a relevância da argumentação, pois as instituições apresentam provas de admissão consideradas complexas e competitivas para avaliar as habilidades dos candidatos em diversas áreas do conhecimento. Dentre os requisitos, há a necessidade do emprego da norma padrão da Língua Portuguesa por meio de um texto dissertativo-argumentativo referente a uma questão relativa à sociedade, ou seja, os vestibulandos devem saber argumentar sobre uma temática relevante apresentada pela banca examinadora, entretanto, duvidamos dessas exigências dos vestibulares, incluindo a avaliação referente à redação, pois muitos deles desconsideram o repertório e outros conhecimentos que o candidato pode possuir.

Neste estudo, queremos saber como/se os estudantes do ensino médio de escolas públicas argumentam sobre as cotas raciais em universidade públicas brasileiras, pois entendemos que há um assunto polêmico em que o sujeito poderá argumentar e disputar os sentidos. Ademais, questionamo-nos: o sujeito-aluno do terceiro ano do Ensino Médio é incentivado pela escola, por meio de suas práticas, a argumentar sobre um tema relevante para sua vida?

Reconhecemos a cota de recorte racial como um assunto controverso e visamos conceber um estudo que vincule a língua, em sua perspectiva discursiva, a escola, grande Aparelho Ideológico do Estado (ALTHUSSER, 1971) e uma temática polêmica social, pois esses sentidos podem favorecer a argumentação. Com base nos estudos da 
$\mathrm{AD}$, analisaremos como os sentidos sobre cotas circulam no discurso oficial e nos textos de sujeitos-alunos que cursam o terceiro ano do Ensino Médio.

Partindo dos elementos relacionados a esse trabalho, objetivamos:

- $\quad$ Ler e compreender a Lei $n^{\circ} 12.711$, de 29 de agosto de 2012, que viabiliza a aplicação das cotas em universidades federais;

- Analisar os textos dissertativo-argumentativos de sujeitos do Ensino Médio de duas escolas públicas do Estado de São Paulo sobre cotas raciais, uma vez que essa produção textual constituirá o corpus de nossa pesquisa.

A $\mathrm{AD}$ é a vertente teórica para ler e compreender os sentidos presentes na Lei $\mathrm{n}^{\circ}$ 12.711 e no corpus; isso se faz necessário devido às condições de produção que possibilitam a emergência da temática de cotas no espaço público escolar por meio do discurso jurídico. Recorremos a esse tema polêmico para motivar a reflexão e a discussão com os sujeitos-alunos com a hipótese de que eles sintam-se motivados a disputar os sentidos a fim de propiciar a escrita do texto dissertativo-argumentativo.

Em suma, esta dissertação é constituída do seguinte modo: o primeiro capítulo versará sobre alguns dos conceitos primordiais da $\mathrm{AD}$ pecheutiana bem como apresenta estudos acerca da argumentação. O segundo capítulo trará os sentidos "oficiais" que são difundidos no Brasil sobre as cotas raciais; para tal, nos basearemos, principalmente, na lei que visa à instauração de políticas afirmativas em universidades federais. Sequencialmente, o terceiro capítulo mostra o percurso metodológico e as condições de produção encontradas nas escolas públicas estaduais, sendo essa tarefa primordial para a compreensão e interpretação do corpus. Além disso, o quarto capítulo apresenta a análise dos sentidos sobre cotas raciais presentes nos textos dos sujeitos-alunos, ou seja, apresentamos as análises discursivas das dissertações. Por fim, o quinto capítulo tece algumas considerações referentes ao nosso estudo. 


\title{
1. ANÁLISE DO DISCURSO E ARGUMENTAÇÃO
}

\author{
Estou farto do lirismo comedido \\ lirismo bem comportado \\ Do lirismo funcionário público com livro de \\ ponto expediente protocolo e manifestações \\ de apreço ao sr. diretor. \\ Estou farto do lirismo que para e vai \\ averiguar \\ no dicionário o cunho vernáculo de um \\ vocábulo \\ -Não quero mais saber do lirismo que não é \\ libertação.
}

(BANDEIRA, 1986, p. 30)

Trabalhamos na perspectiva da AD de linha pecheutiana e neste capítulo mostramos conceitos importantes desse escopo teórico. Além disso, trazemos reflexões acerca dos estudos argumentativos, cujas noções serão primordiais para a análise dos textos dissertativo-argumentativos dos sujeitos-alunos.

A AD de linha francesa pecheutiana é uma ciência que tem sido mais estudada, a partir do final do século XX. O seu fundador, Michel Pêcheux, filósofo francês, que na década de 1960, juntamente com outros intelectuais, passou a conceber uma orientação teórica que aliava três grandes áreas do conhecimento: a linguística, o materialismo histórico e a psicanálise. A abordagem que caracteriza a teoria traz língua em sua relação à história, à ideologia e à discursividade. Considerando a vertente da $\mathrm{AD}$ na perspectiva pecheutiana podemos afirmar que o nosso quadro epistemológico articula as seguintes áreas do conhecimento científico:

1. o materialismo histórico, como teoria das formações sociais e de suas transformações, compreendida aí a teoria das ideologias;

2. a linguística, como teoria dos mecanismos sintáticos e dos processos de enunciação ao mesmo tempo;

3. a teoria do discurso, como teoria da determinação histórica dos processos semânticos.

Convém explicar ainda que estas três regiões são, de certo modo, atravessadas e articuladas por uma teoria da subjetividade (de natureza psicanalítica) (PÊCHEUX; FUCHS, p. 163-64, 1990).

De acordo com Pêcheux (1981), o estruturalismo filosófico da década de 1960 preocupou-se com a leitura (interpretação) de discursos ideológicos, mostrando-os como resposta a três ideias dominantes na época: o espiritualismo filosófico, que possui uma concepção religiosa da leitura; as formas cotidianas secularizadas dessa leitura baseadas 
na análise de conteúdo focado nas figuras do emissor/receptor; e o objetivismo científico, que apresentava a "teoria da informação". Entretanto Marx, Nietzsche, Freud e Saussure refletiram sobre questões fundadoras para nosso escopo teórico, tais como falar, escrever, escutar e ler. Destacamos, também, que Freud (1905) pensava sobre o "significado" do discurso do inconsciente, o que também contribuiu para a constituição da AD.

Além dos autores supracitados, ressaltamos o filósofo Althusser, visto que diversas postulações althusserianas foram citadas e repensadas por Pêcheux, sobretudo na obra "Semântica e Discurso: uma crítica à afirmação do óbvio" (1988). Althusser (1971) teorizava sobre a sociedade, as relações de reprodução, a ideologia dominante e os "aparelhos ideológicos de Estado" (AIE, doravante), como a família, a religião, a divisão do trabalho social e a escola. Com base nessa teoria e na relação da ideologia com a linguagem, Gadet e Pêcheux (1981, p. 98) explicitam que:

A análise de discurso deixa de ser uma questão de reconstrução das variantes homogêneas de uma estrutura de ideologia (ou ideologias) para ser, em vez disso, uma questão de exploração desse jogo de heterogeneidades discursivas móveis que geram eventos específicos às lutas ideológicas do movimento.

Diante dessa relação apontada pelos autores, que vincula as lutas ideológicas ao discurso, fez-se importante estudarmos o livro de Althusser, "Ideologia e Aparelhos Ideológicos de Estado" (1971), que postula que toda a formação social produz e reproduz as condições de sua produção, pois deve reproduzir as forças produtivas e as relações de produção existentes.

Acerca da reprodução dos meios de produção, o autor escreve sobre a existência da necessidade de reprodução das condições materiais de produção e, também, que a reprodução da força de trabalho (força reprodutiva), assegurada por meio do salário, representa parte do valor produzido pelo dispêndio da força de trabalho. E surge uma exigência importante: a força de trabalho deve ter competência e ser qualificada e o espaço no qual o trabalhador pode ser qualificado dever ser representado pela Escola, cuja função é transmitir e legitimar o conhecimento a fim de que ele seja utilizável em diferentes lugares da produção. A escola ensina, também, as regras e costumes indicados para o comportamento social, bem como se deve falar e escrever. Logo, a escola não tem um papel inocente e redentor da sociedade, mas trata-se de: 
uma reprodução da submissão desta às regras da ordem estabelecida, isto é, uma reprodução da submissão desta ideologia dominante para os operários e uma reprodução da capacidade de manejar bem a ideologia dominante para os agentes da exploração e da repressão, a fim de que possam assegurar também, pela palavra, a dominação da classe dominante" (ALTHUSSER, 1971, p. 21-22).

Entendemos, com base em Althusser (1971), que a instituição escolar é responsável por perpetuar a ideologia da classe dominante de modo, aparentemente, neutro, pois ela direciona uma educação para os operários e outra para os agentes de exploração e repressão, em outras palavras: há uma educação direcionada à classe dominante e outros conhecimentos destinados à classe dominada. Além da escola, há, também, a Igreja e o Exército que ensinam saberes práticos, sempre em moldes que asseguram a sujeição à ideologia dominante.

Althusser (1971) apresenta-nos sua concepção de infraestrutura (ou base econômica) e a superestrutura que comporta em si dois níveis: o jurídico-político (o direito e o Estado) e a ideologia (as diferentes ideologias, religiosas, moral, jurídica, política, etc.); uma representação possível para essa concepção seria um edifício, em que a superestrutura e a ideologia estão no topo e necessitam da infraestrutura, que é a base, e é constituída pelo aspecto econômico, que de um modo ou de outro é um determinante social. O filósofo define o Estado como uma máquina de repressão que utiliza a violência, bem como a ideologia, para perpetuação do seu poder por meio dos Aparelhos Ideológicos de Estado:

Um Aparelho ideológico de Estado é um sistema de instituições, organizações e práticas correspondentes, definidas. Nas instituições, organizações e práticas desse sistema é realizada toda a Ideologia de Estado ou uma parte dessa ideologia (em geral, uma combinação típica de certos elementos). A ideologia realizada em um AIE garante sua unidade de sistema "ancorada" em funções materiais, próprias de cada AIE, que não são redutíveis a essa ideologia, mas lhe servem de "suporte" (ALTHUSSER, 1999, p. 104).

Um AIE é um sistema de instituições que por meio de seus ritos e valores asseguram a perpetuação da ideologia da classe dominante, independentemente de serem públicas ou privadas. Visto que essas instituições são elementos basilares de nossa sociedade, é necessário que as reconheçamos e que nos atentemos ao seu funcionamento:

- o AIE religioso (o sistema de diferentes igrejas), 
-o AIE escolar (o sistema das diferentes escolas públicas e particulares),

- o AIE familiar,

- o AIE jurídico,

- o AIE político (o sistema político de que fazem parte os diferentes partidos),

- o AIE sindical,

- o AIE da informação (imprensa, rádio, televisão, etc.),

- o AIE cultural (Letras, Belas Artes, desportos, etc.)

(ALTHUSSER, 1971, p. 44)

Devido à abrangência do AIE e a sua aparente neutralidade, consideramos que a escola se mostra como um poderoso AIE, uma vez que grande parte da população brasileira frequenta ou frequentou as instituições escolares. Além disso, em famílias em que os pais trabalham por longas jornadas, a escola se mostra como uma necessidade.

Ainda segundo Althusser (1971), o aparelho ideológico não produz as ideologias, mas é nele que elas se realizam: Cassin (2002, p. 118) corrobora com a afirmação de Althusser (1971) ao postular que "Quanto à ideologia dominante, ela existe nas instituições escolares como determinados elementos da ideologia de Estado no interior destas instituições.”. Portanto, apesar de a escola se apresentar como transparente e portadora (e promotora) da voz da ciência, ela é um AIE utilizado pela burguesia para a manutenção da estrutura social existente, em dado momento sóciohistórico. Em outras palavras, a escola funciona como um aparelho ideológico com a função de manutenção de privilégios, da classe dominante, e evidências de determinados sentidos; sendo assim, na instituição escolar há a paráfrase dos discursos que materializam a ideologia dominante.

Para Marx (1980), a ideologia passa a ser o sistema de ideias, das representações que dominam o espírito de um homem ou de um grupo social. Althusser (1971) elabora três teses centrais que sintetizam sua teoria acerca da ideologia: "A Ideologia é uma 'representação' da relação imaginária dos indivíduos com suas condições reais de existência” (ALTHUSSER, 1971, p. 53); “A Ideologia não tem história”(ALTHUSSER, 1971,p. 71); e "A ideologia interpela os indivíduos como sujeitos” (ALTHUSSER, 1971 p. 93).

A primeira tese, “A Ideologia é uma 'representação' da relação imaginária dos indivíduos com suas condições reais de existência”, está relacionada ao seguinte questionamento: “porque 'precisam' os homens desta transposição imaginária das suas condições reais de existência, para se 'representarem' as suas condições de existência reais?” (ALTHUSSER, 1971, p. 79). Segundo o autor, a primeira resposta é dada a 
partir da constatação da existência de um pequeno grupo de homens (padres e déspotas) que assentavam a sua dominação e exploração do povo numa representação falseada do mundo que inventaram para subjugar os espíritos, dominando a imaginação destes. A segunda resposta, ainda de acordo com o filósofo, é igualmente falsa e está vinculada à alienação material que reina nas condições de existência dos próprios homens, pois "Marx defende a ideia feuerbachiana segundo a qual os homens fazem uma representação alienada, imaginária, das suas condições de existência porque estas condições de existência são em si alienantes" (ALTHUSSER, 1971, p. 80). Sendo assim, na ideologia, o que é representado não é o sistema das relações reais que governam a existência dos indivíduos, mas a relação imaginária dos indivíduos com as relações reais em que vivem.

A segunda tese está vinculada ao fato de que uma ideologia existe sempre em um aparelho ideológico e em suas práticas, o que conota uma existência material, pois as ideias de um sujeito existem nos seus atos e práticas que são observáveis por meio de rituais de um aparelho ideológico (como, por exemplo, uma missa, um enterro, um dia de aulas, uma reunião de um partido político). Tanto a primeira tese quanto a segunda dependem da noção de sujeito, pois é por meio dele que a ideologia atua.

A terceira tese postula que "A ideologia interpela os indivíduos como sujeitos", pois só existe ideologia pelo sujeito e para sujeitos: "a categoria de sujeito só é constitutiva de toda ideologia, na medida em que toda ideologia não tem por função (que a define) 'constituir' os indivíduos concretos em sujeitos" (ALTHUSSER, 1971, p. 94). Assim, não é possível pensar em uma ideologia sem o sujeito, visto que a ideologia recruta sujeitos entre os indivíduos, ou transforma os indivíduos em sujeitos, por meio da interpelação ideológica. Segundo o professor Cassin (2002, p. 37) Althusser “[...] tem como objetivo reafirmar a ideologia como instrumento de persuasão e não como elemento de repressão e de mostrar os mecanismos que a ideologia utiliza para levar os indivíduos a agir sozinhos sem a necessidade de agentes de repressão". O sujeito é capturado pela ideologia sem a necessidade da repressão, ademais, mesmo os AIE que agem essencialmente pela repressão, não o fazem sem a ideologia.

Althusser (1971) postula ainda que a ideologia sempre-já interpelou os indivíduos como sujeitos, pois os indivíduos são sempre-já sujeitos.

Para Orlandi (2001, p. 46) a "ideologia faz parte, ou melhor, é a condição do sujeito e dos sentidos. O indivíduo é interpelado em sujeito pela ideologia para que se produza o dizer" (ORLANDI, 2001, p. 46). Nosso estudo se refere ao aluno, 
frequentemente, como sujeito ou sujeito-aluno, pois como todo indivíduo ele já foi interpelado em sujeito por uma ideologia.

De fato, a ideologia e o sujeito estabelecem uma relação intrínseca e, de acordo com Orlandi (2001, p. 45), um dos objetivos da AD é re-significar a noção de ideologia a partir da consideração da linguagem. Trata-se assim de uma definição discursiva de ideologia visto que não há discurso sem sujeito e não há sujeito sem ideologia, pois "a ideologia aparece como efeito da relação necessária do sujeito com a língua e com a história para que haja sentido"(ORLANDI, 2001, p.48). O modo de compreendemos a ideologia é considerando o discurso do sujeito, pois a ideologia se materializa nesse discurso. Por meio das vozes de autoridade (como as leis, o livro didático e a mídia), interpretamos que, frequentemente, a ideologia dominante é capaz de materializar sentidos nos textos dos sujeitos-alunos.

Ao pensarmos sobre a concepção de sujeito é necessário aliar três aspectos essenciais: o seu caráter histórico, ideológico e social. A compressão desse conceito é basilar para a $\mathrm{AD}$, pois:

ao trabalharmos com a noção de sujeito numa perspectiva discursiva, é preciso esclarecer que não estamos trabalhando com o indivíduo, o sujeito empírico, mas com o sujeito do discurso que, ao produzir um determinado discurso, está duplamente determinado: pela ideologia e pelo inconsciente. Essa dupla determinação, como nos mostra Pêcheux (1975), produz 'um tecido de evidências 'subjetivas' (1995, p. 153-os grifos são do autor), a partir das quais o sujeito se constitui. O sujeito, assim constituído, vê-se como fonte do que diz e a ideologia, enquanto mecanismo de produção de sentidos produz o efeito de evidência e de transparência do sentido que produz. No entanto, tais evidências são da ordem do funcionamento do imaginário, que resultam no efeito-sujeito e, também, nos efeitos de sentido, uma vez que não há sujeito sem ideologia, tampouco há sentido único. Portanto, nessa perspectiva, a ideologia é responsável pela constituição do indivíduo em sujeito e o inconsciente é responsável pela produção do imaginário de autonomia do sujeito, que pensa controlar e ser origem do discurso que produz. E uma das formas, senão a principal, de materialização do discurso é a escrita (GRIGOLETTO; AGUSTINI, 2009, p. 370).

Em nossa perspectiva, o sujeito não é representado pelo empírico e pelo lógico, há aqui o sujeito do discurso que, ao produzir o seu discurso, é determinado não apenas pela ideologia, mas, também, pelo seu inconsciente. De acordo com Freud (1905), o sujeito acredita ser a fonte de seu dizer, pois a ideologia atua no efeito de evidência dos 
sentidos e o inconsciente é responsável pela produção do imaginário de autonomia do sujeito, que acredita controlar o seu discurso e expressar exatamente o que ele pensa. Dessa forma, é por meio do seu discurso que interpretamos as marcas da posição que o sujeito-aluno ocupa ao construir sentidos sobre as cotas raciais.

Pêcheux (1988), com base na interpretação de Freud (1905) dos conceitos de "sistema pré-consciente-consciente" e o "sistema inconsciente", e, nos estudos de Lacan (1979) sobre o pré-consciente ${ }^{1}$, defende que o sujeito se constitui pelo esquecimento daquilo que o determina e criou a teoria das ilusões ou esquecimentos, pois os "esquecimentos" são inerentes ao discurso. Em conformidade com isso, Pacífico (2002, p. 36) assevera que:

a ilusão $\mathrm{n}^{\circ} 1$ é um ocultamento ideológico, um apagamento para o sujeito do processo pelo qual uma sequência discursiva concreta é produzida ou reconhecida como tendo sentido, o que faz o sujeito achar que é a origem do seu dizer, que o sentido do seu discurso "nasce" nele; o sujeito não reconhece a inclusão daquilo que ele diz em determinada formação discursiva e não em outra, uma vez que é interpelado pela ideologia; logo, a ilusão $\mathrm{n}^{\circ} 1$ é inconsciente. Já, a ilusão $\mathrm{n}^{\mathrm{o}} 2$ faz o sujeito acreditar que aquilo que ele diz corresponde ao que ele pensa (transparência do pensamento), como se existisse relação entre a palavra e o mundo. É um ocultamento linguístico (préconsciente/consciente), está relacionado à seleção de palavras e da forma como colocá-las em discurso (paráfrase), isto é, escolher uma maneira entre as várias possíveis de se dizer a mesma coisa.

$\mathrm{O}$ esquecimento $\mathrm{n}^{\mathrm{o}} 1$ tem um funcionamento na ordem do inconsciente, de modo que o sujeito não percebe que seu discurso está inscrito em uma determinada formação discursiva (FD, doravante). FD deve ser compreendida como "uma formação ideológica dada, isto é, a partir de uma posição numa conjuntura dada, determinada pelo estado de luta de classes, determina o que pode e deve ser dito" (PÊCHEUX, 1988, p. 147). O sujeito não reconhece que a FD é responsável por determinar aquilo que pode e deve ser dito em uma determinada conjuntura, tampouco ele se dá conta de que se identifica com uma FD, e não de outra, porque ele já foi interpelado pela ideologia. Ademais, esse conceito tem vinculação com os sentidos das palavras, pois uma palavra pode ter sentidos distintos dependendo da FD na qual ela se insere; sendo assim, não há a transparência nos sentidos e na linguagem e a não evidência permanece opaca, visto

\footnotetext{
1“A sintaxe, exatamente, é pré-consciente” (LACAN, 1979, p. 70).
} 
que pelo trabalho da ideologia ocorre a ilusão da transparência, como se o sentido só pudesse ser um.

O esquecimento $n^{\circ} 2$ está vinculado ao sujeito acreditar que é capaz de dizer exatamente aquilo que pensa, como se as palavras pudessem estabelecer uma relação direta com o mundo. Esse esquecimento tem vinculação com o funcionamento do sujeito do discurso e com sua inserção na FD com a qual ele identifica-se; devido a essa relação, o sujeito acredita ter "liberdade" para escolher um enunciado em detrimento de outro; todavia, esses enunciados fazem parte da FD que, ideologicamente, capturou-o. De acordo com Pêcheux (1988), o sujeito-falante seleciona no interior da formação discursiva que o domina formas e sequências que nelas se encontram em relação de paráfrase.

O sujeito, mesmo antes de nascer, já faz parte de uma FD que está relacionada a uma formação ideológica e ocorre devido à interpelação do sujeito por meio da ideologia. Podemos pensar, então, que há um "teatro da consciência (eu vejo, eu penso, eu falo, eu te vejo, eu te falo, etc.) é observado dos bastidores, lá de onde se pode captar que se fala $d o$ sujeito, que se fala ao sujeito, antes que o sujeito possa dizer: 'Eu falo", (PÊCHUX, 1988, p. 140, grifo do autor).

Pêcheux (1988) reflete sobre a questão já abordada por Althusser (1971) em relação à evidência do sujeito tido como único que, para a pergunta "quem é?" responde “sou eu". (PÊCHUX, 1988, p. 141). Tais apontamentos nos levam a reflexões sobre a não transparência da linguagem e a evidência de sentidos em uma determinada FD:

É a ideologia que fornece as evidências pelas quais "todo mundo sabe" o que é um soldado [...] evidências que fazem com que uma palavra ou um enunciado "queiram dizer o que realmente dizem" e que mascaram, assim, sob a "transparência da linguagem", aquilo que chamaremos o caráter material do sentido das palavras e dos enunciados (PÊCHEUX, 1988, p. 146).

Pensar na evidência de sentidos tem relação com a não transparência da linguagem, em que o sujeito é capturado pela ideologia e identifica-se com uma dada FD, a captura ocorre quando já não se sabe mais a origem de um dizer e surgem questões que são consideradas óbvias, pois "todo mundo sabe" ou tem conhecimento sobre um determinado sentido que é dominante naquela FD e a questão da constituição 
do sentido soma-se à constituição do sujeito no interior da interpelação (PÊCHUEX, 1988, p. 140).

Diante dessas postulações teóricas, concordamos que "os indivíduos são 'interpelados' em sujeitos-falantes (em sujeitos de seu discurso) pelas formações discursivas que representam 'na linguagem' as formações ideológicas que lhes são correspondentes". (PÊCHEUX, 1988, p. 147). Esse processo ocorre na medida em que há a interpelação do indivíduo em sujeito de seu discurso e se efetua pela identificação (do sujeito) com a formação discursiva que o domina (isto é, na qual ele é constituído como sujeito) (PÊCHEUX, 1988, p. 150).

De acordo com Orlandi (1994), a tarefa da AD é analisar os processos característicos de uma formação discursiva que devem dar contra da articulação entre o processo de um discurso (incluída a língua) e as condições em que ele é produzido. Para analisar um discurso, é preciso atentar-se não apenas para o texto, em sua materialidade estrutural e as suas características gramaticais, mas é preciso compreender as condições nas quais o discurso foi produzido. Ademais, é importante saber qual é a formação discursiva em que o sujeito está inserido e quais são os efeitos de sentido possíveis a partir disso. Sendo assim, a formação discursiva está relacionada com a concretização da ideologia: e "as formações discursivas vão representar uma das formas materiais da ideologia, já que é na formação discursiva que vamos observar os movimentos do dizer no discurso" (SCHONS; MITTMANN, 2009, p. 299).

Se, por um lado, sabemos que o sujeito, para sustentar seu dizer, vai filiar-se a uma ou a outra formação discursiva, por outro, entendemos que pode haver a deriva dos sentidos, pois o sujeito é sempre passível de lapsos e falhas. Nas análises dos textos dos sujeitos-alunos, nós observaremos como eles se posicionam em relação às cotas raciais, para notar sua identificação com determinada formação discursiva ou com outra; todavia, reconhecemos que há, como Coracini (2007, p. 136) afirma, a “(im) possibilidade da língua feita objeto, um todo coerente, uno, homogêneo". Logo, percebemos que a formação discursiva, também, não é homogênea.

Há conceitos da $\mathrm{AD}$ que possuem laços em sua constituição e que são capazes de nos ajudar a compreender, nos discursos, o processo de construção dos sentidos, visto que "existe um entrelaçamento - sujeito - lugar social - formação discursiva interdiscurso - costurando toda construção de sentido." (PACÍFICO, 2002, p. 44). A noção de interdiscurso está ligada, também, à linguagem e ao inconsciente e a sentidos que circularam, anteriormente, e que podem sustentar o dizer de um sujeito. $O$ 
interdiscurso é, segundo Orlandi (1998) e Pacífico (2002), “o já-dito que sustenta a possibilidade mesma de dizer: conjunto do dizível que torna possível o dizer e que reside no fato de que algo fala antes, em algum lugar" (ORLANDI, 1998, p. 9) e "a noção de formação discursiva e de interdiscurso, mostrando que existe algo que é anterior, chamado de já-lá, e exterior à produção e à leitura de textos e o sentido depende da relação do sujeito com isso tudo." (PACÍFICO, 2002, p. 53). A produção e a leitura de textos dependem da relação do sujeito com o exterior e com o anterior, ou seja, com a formação discursiva e o interdiscurso.

Todavia, é preciso ponderar sobre as relações que o sujeito estabelece com a formação discursiva, com o interdiscurso e com a memória. Segundo Orlandi (1998, p.12), o papel do analista do discurso, em sua escuta, é o de explicitar os gestos de interpretação que se ligam aos processos de identificação dos sujeitos, suas filiações e sentidos: descrever a relação do sujeito com a memória.

Uma memória não poderia ser concebida como uma esfera plena, cujas bordas seriam transcendentais históricos e cujo conteúdo seria um sentido homogêneo, acumulado ao modo de um reservatório: é necessariamente um espaço móvel de divisões, de disjunções, de deslocamentos e de retomadas, de conflitos de regularização... Um espaço de desdobramentos, réplicas, polêmicas e contra-discursos.

(PÊCHEUX, 1999, p. 56).

A memória, que está relacionada ao sujeito, também é heterogênea, pois é um espaço que tem disjunções e conflitos de regularização nos quais há polêmicas e contradiscursos.

Memória discursiva seria aquilo que, face a um texto que surge como acontecimento a ler, vem restabelece os 'implícitos' (quer dizer, mais tecnicamente, os pré-construídos, elementos citados e relatados, discursos-transversos, etc.) de que sua leitura necessita: a condição do legível em relação ao próprio legível. (PÊCHEUX, 1999, p. 52).

Para Orlandi (1998), memória discursiva é o conjunto de dizeres já ditos e esquecidos que determinam o que dizemos. Esses conceitos, também, relacionam-se ao que Pêcheux (1997) chamou de arquivo, que possui um caráter institucional e pode ser entendido, no sentido amplo, como um "campo de documentos pertinentes e disponíveis 
sobre uma questão" (PÊCHEUX, 1997, p. 57). O conceito de arquivo pode ser pensado com o conceito de memória, pois "ela se transforma e está diretamente relacionada à conjuntura sócio-histórica em que o sujeito está inserido, e, dependendo do mesmo, se inscreverá numa determinada rede de memória ou noutra." (GRIGOLETTO; AGUSTINI, 2009, p. 371).

A memória tem um papel primordial, sobretudo quando pensamos nas práticas escolares, porque "o aluno inscreve seu dizer nas redes de memória que regulam o que pode e deve ser dito no espaço escolar" (GRIGOLETTO; AGUSTINI, 2009, p. 371). Muitas vezes, os sentidos tidos como adequados são determinados pelo professor ou, ainda, pelo livro didático. Nesse AIE, que é a instituição escolar, o sentido parafrástico é o mais valorizado. Entretanto, os sentidos podem vir a ser outros e a manutenção das estruturas pode sofrer rachaduras. A leitura, a interlocução e a memória devem estar interligadas para que sustentem uma nova maneira de ler, para que propiciem possíveis abalos nas estruturas educacionais, de modo que o sujeito-aluno tenha mais acesso ao arquivo e tenha a possibilidade de ter discursos que sejam polissêmicos.

Pêcheux (1997) concebe uma visão social do trabalho de leitura que representa coincidências com a sociedade: alguns, e apenas alguns, têm o direito de ler e escrever algo considerado original, enquanto outros apresentam gestos repetidos, ou seja, são sujeitos-leitores apagados pela instituição que os emprega, fato que é intrínseco ao divórcio existente entre o texto literário e o científico e ao fato de essas questões atravancarem os gestos de leitura e de autoria em nossa sociedade: "A arrogância e a condescendência fóbicas dos 'literatos' ameaça isolá-los mais e mais (cultural e politicamente) face à paciente e mordaz modéstia utilitária dos cientistas de arquivo, que têm o futuro diante deles" (PÊCHEUX, 2007, p. 59). Como as formações discursivas não são homogêneas, nem tampouco o discurso ou a linguagem, o sujeito pode romper com isso e gerar discursos que sejam polissêmicos, ou seja, pode ocorrer a parafrasagem. Segundo Maingueneau (1993, p. 96),

A parafrasagem aparece em $\mathrm{AD}$ como uma tentativa para controlar em pontos nevrálgicos a polissemia aberta pela língua e pelo interdiscurso. Fingindo dizer diferentemente a "mesma coisa" para restituir uma equivalência preexistente, a paráfrase abre, na realidade, o bem-estar que pretende absorver, ela define uma rede de desvios cuja figura desenha a identidade de uma formação discursiva. 
A paráfrase pode ser entendida como uma tentativa de controle dos sentidos, para assegurar que esses sejam sempre os mesmos, pois, apesar de aparentarem ser diferentes, trazem em si a ideologia dominante aceita em uma determinada formação discursiva, e a escola é o espaço que, muitas vezes, valoriza esse processo parafrástico favorecendo a estabilização de sentidos.

A produção de linguagem ocorre por meio de junção de dois processos: o parafrástico e o polissêmico, que são responsáveis pelo "mesmo" e pelo "diferente". A língua tem em si a heterogeneidade, é aberta e se relaciona com o interdiscurso; a

A. o Mesmo: apesar da variedade da situação e dos locutores, há um retorno ao mesmo espaço dizível (Paráfrase).

B. O diferente: nas mesmas condições de produção imediatas (locutores e situação) há no entanto um deslocamento, um deslizamento de sentidos (Polissemia) (ORLANDI, 1998, p. 15)

Além da existência da paráfrase, há a polissemia, que ocorre por meio da ruptura de processos de significação e favorece o movimento e a transformação não apenas dos sentidos, mas, também, dos sujeitos. Os textos polissêmicos são discursos que apresentam descolamentos, pois os sentidos deslizam.

No capítulo direcionado às analises, visamos a entender se a escola, as leis e as redações se sustentam nos $\mathrm{AIE}$, logo, na paráfrase, ou se há textos que valorizam a polissemia.

Orlandi (2011), em seu livro "A linguagem e seu funcionamento: as formas do discurso", analisa textos que se baseiam na paráfrase. A autora defende que o discurso não é apenas um meio para a transmissão de informação, porque é capaz de gerar efeitos de sentido, uma vez que os traços são ideologicamente interpretáveis e por meio da análise é possível encontrar os indícios da formação discursiva e da formação ideológica que sustentam determinado dizer. Nesse grupo de paráfrases escolhido por Orlandi (2011, p. 123) as marcas ideológicas estão presentes:

(9) Embora trabalhe bem é preto.

(10) Trabalha bem mas é preto.

(11) Embora seja preto trabalha bem.

(12) É preto mas trabalha bem

(13) É preto embora trabalhe bem.

(14)Trabalha bem embora seja preto. 
Orlandi (2011) conclui que nas paráfrases as diferenças não são de registro, mas de argumentação. Um aspecto primordial do estudo de Orlandi (2011) é a presença da formação ideológica que diferencia os afrodescendentes dos brancos: "A formação ideológica é a mesma: a que distingue preto e branco, em termos racistas. Ainda a que dissesse 'trabalha bem porque é preto' estaria no interior da mesma ordem racista. (ORLANDI, 2011, p. 124). As frases transcritas pela autora possuem estruturas parafrásticas, com efeitos de sentidos peculiares em cada enunciado. A formação ideológica possui valores que são racistas e preconceituosos, uma vez que uma formação ideológica não racista não precisaria vincular a cor da pele, ou a etnia, ao trabalho ou mesmo à qualidade dele.

É necessário analisar esse tipo de enunciado na escola, e fora dela, pois sentidos semelhantes a esse circulavam (e ainda circulam), inadvertidamente, em nossa sociedade no século passado (e neste século). Expressões populares como "é preto de alma branca", estão, aparentemente, tentando elogiar o "preto". Contudo, o sujeito que se identifica com essa formação ideológica e discursiva acredita que os afrodescendentes são inferiores aos demais (fato que era aceitável em um país como o Brasil que se sustentou por anos com o regime escravocrata).

Com base nesses enunciados que possuem sentidos parafrásticos, Orlandi (2011) considera possível aliar ao processo da argumentação, no seu sentido retórico, à presença de processos semânticos da linguagem que seriam a paráfrase e a polissemia. A autora postula três elementos que presidem a argumentação, em termos de discurso: "relação de forças (lugares "sociais" e posição relativa no discurso); relação de sentido (o "coro de vozes" em um dizer; a relação que existe entre os vários discursos); e a antecipação". (ORLANDI, 2011, p. 128). O mecanismo de argumentação resulta numa diferença do funcionamento discursivo e essa diferença mostra o jogo da interação, de interlocução, no texto. Assim, a argumentação concorre para a distinção de estilos e de formações discursivas, de acordo com Orlandi (2011).

Notamos, então, a viabilidade de estudar os aspectos argumentativos do discurso; todavia, sabemos que esses estudos, de modo geral, estão pautados em perspectivas analíticas distintas das nossas. Seria possível tornar essas bases epistemológicas complementares? É possível construir pontes de interlocução entre os pressupostos da $\mathrm{AD}$ pecheutiana e os estudos sobre argumentação, visto que argumentar é algo constitutivo da linguagem. Reconhecemos que este trabalho não conseguirá 
"resolver" essa questão; entretanto, queremos avançar e motivar outras pesquisas que, também, apontem para novas tendências para os estudos discursivos. Apresentaremos, a seguir, alguns estudos relevantes sobre argumentação e discurso.

A argumentar é primordial para o sujeito, visto que ele pode conceber um discurso que contenha seu posicionamento acerca de uma dada questão. De acordo com os estudos argumentativos tradicionais que valorizam autores referenciais, como Aristóteles e Perelman, a Retórica contribuiu para os estudos da linguagem. E em consonância com essa perspectiva, Mosca (2001) defende que a Retórica é tangencial aos estudos argumentativos, pois a contemporaneidade é dotada de conflitos que demandam negociação e o exercício verbal é visto, então, como um espaço polêmico frente ao dissenso, à adversidade:

O caráter da Retórica, ao mesmo tempo prático (arte da construção do discurso) e teórico (teoria e análise desses mesmos discursos) responsável pelo interesse que esta vem suscitando nas últimas décadas, impondo-se junto a várias disciplinas como o Direito, a Ética, a Política e a Psicanálise. Num mundo em que os conflitos e as controvérsias são inevitáveis, as negociações e a argumentação fazem parte do cotidiano das nações, das comunidades e das pessoas (MOSCA, 2004, p. 45).

Mosca (2004) apresenta uma perspectiva humanística da Retórica: o mundo possui diversos conflitos e controvérsias, para resolução dessas contendas as negociações e a argumentação devem ser elementos presentes no cotidiano. A Retórica tem seu carácter prático, pois é a arte da construção do discurso, e, também, seu aspecto teórico na medida em que se mostra como um dispositivo de análise desse discurso e se vincula a grandes áreas do conhecimento como o Direito, a Ética, a Política e a Psicanálise. Notamos que:

As retóricas de hoje [...] permanecem fiéis ao programa de sua antecessora clássica: contribuir para constituir uma ciência do discurso dos homens em sociedade. Elas podem, portanto, desempenhar o papel de um horizonte em que se concretiza a necessária interdisciplinaridade das ciências humanas (KLINKENBERG, apud MOSCA, 2004, p. 14).

Essa interdisciplinaridade é relevante para constituição da $\mathrm{AD}$ e da argumentação, pois a argumentação e a Retórica são apresentadas, muitas vezes, como 
sinônimos e esta tem como base conceitos clássicos que visavam a contribuir para a ciência do discurso na sociedade apresentam a sua interdisciplinaridade nas ciências humanas.

A obra aristotélica composta por Tópicas, Refutações sofisticas e Retórica que possui três livros (o primeiro aborda o raciocínio; o segundo se ocupa em apresentar a teoria das emoções; o terceiro demonstra a presença de estilos e figuras) constitui o referencial teórico mais representativo em relação à argumentação. Aristóteles, que estudou sobre a questão, desde a Grécia Antiga, interpretava a argumentação como um elemento essencial para a vivência em sociedade. Sendo assim, Retórica (2011) é “considerada como a primeira reflexão sistemática, teórica e prática, desenvolvida sobre a arte oratória e as técnicas de persuasão" (ZOPPI-FONTANA, 2010, p.186). Além disso, nesse convívio era preciso apresentar uma defesa de um ponto de vista em que era necessário cativar o auditório e fazê-lo aderir a uma tese. Em outras palavras, nessa perspectiva teórica, a retórica e a argumentação são vistas como algo primordial ao indivíduo, de modo que "todos procuram discutir e sustentar teses, realizar a própria defesa e a acusação dos outros" (ARISTÓTELES, 2011, p. 39).

As postulações de Aristóteles se mostram ainda como referenciais para os estudos sobre retórica e argumentação. Considerando os estudos aristotélicos, Fiorin (2015, p. 259) questiona se "estamos condenados a repetir os antigos?" e conclui que "temos sempre que nos valer deles. Entretanto, o que as diferentes teorias do discurso devem fazer é herdar a retórica no estudo dos procedimentos discursivos, levando em consideração séculos de estudos já realizados" (FIORIN, 2015, p. 259), ou seja, é necessário aprimorar os estudos argumentativos para que, a partir de Aristóteles, outros estudos apareçam. Como posteriores aos estudos aristotélicos:

Assiste-se, a partir de então, ao surgimento de diversas abordagens da argumentação: uma lógica de conteúdo (lógica substancial, de Toulmin; lógica não formal, de Blair e Johnson; lógica natural, de Grice e cognitiva, de Vignaux); estudos da argumentação que remetem à pragmática linguística (Pragmática de Ducrot e Anscombre e a pragmatica-dialética, de Van Eemeren e Grootendorst); uma análise enunciativa da argumentação (visão retórica clássica ou neo-retórica, como a do Grumo $\mu$, de Perelman, Meyer e outros); a concepção interacional da argumentação (Schiffrin, Vion, Plantin, Orecchioni e outros) (MOSCA, 2004, p. 5). 
Dentre os autores citados acima, destacamos Chaim Perelman e OlbrechtsTyteca, uma vez que seus postulados se tornaram referência na teoria argumentativa, não apenas no âmbito da linguagem, como, também, no plano do Direito: o "Tratado Da Argumentação- A Nova Retórica", de Chaim Perelman e Olbrechts-Tyteca. Os estudos da argumentação foram, por algum tempo, relegados, mas, a partir desse tratado, que foi publicado no final da década de 50 do século XX, voltaram a surgir reflexões sobre a importância da argumentação para a vida em sociedade, pois, de acordo com essa base epistemológica, a palavra e a argumentação apresentam-se cada vez mais primordiais. Assim,

o retorno à retórica preconizado por Perelman \& Olbrechts-Tyteca em 1958 não é simplesmente a marca de um otimismo: é uma reivindicação ética que se faz através da reafirmação da função social das trocas verbais como substitutas da violência (de qualquer ordem que seja), e a lembrança da responsabilidade cidadã que, de qualquer possibilidade de influência mútua pelo logos, revela-se esvaziada de sua substância (AMOSSY, 2007, p. 128).

Perelman é considerado um autor neoaristotélico que valoriza o retorno à retorica devido aos preceitos humanísticos. Amossy (2007) também concorda com a retomada desse escopo teórico e defende que os estudos de Perelman e OlbrechtsTyteca (1958) representam uma reivindicação ética, reafirma a função social das trocas verbais em detrimento das práticas pautadas na violência, conceitua a retórica como a arte de persuadir relacionada ao lugar central do logos em sua relação com ethos e com o pathos.

Para Amossy (2007), a argumentação depende das possibilidades da língua e das condições sociais e institucionais que determinam parcialmente o sujeito, fora dessas condições a orientação ou a dimensão argumentativa do discurso não poderia ser apreendida com discernimento. A autora defende que é na espessura da língua que se forma e se transmite a argumentação e é através de seu uso que a argumentação se instala. Sendo assim, não é possível pensar argumentação sem o sujeito do discurso. Suas contribuições asseveram que:

É preciso insistir aqui sobre dois pontos que caracterizam a argumentação no discurso como um ramo da análise do discurso. Trata-se nesse caso (1) da inscrição da argumentação na materialidade linguageira em que ela participa do funcionamento global do discurso, 
e (2) da necessidade de examinar os funcionamentos argumentativos no entrecruzamento do linguístico com o social, apreendendo 'o discurso como imbricação de um texto e de um lugar social'- de maneira que o objeto da AD 'não seja nem a organização textual nem a situação de comunicação, mas aquilo que os une através de um dispositivo de enunciação específico. Esse dispositivo concerne ao mesmo tempo ao verbal e ao institucional' (definição de Maingueneau no Dictionnaire, especificada em Marges linguistiques, 2005) (AMOSSY, 2007, p. 128, grifo nosso).

A autora valoriza os estudos da $\mathrm{AD}$ com base na argumentação em sua materialidade linguageira e no funcionamento argumentativo vinculado a aspectos sociais, ou seja, aquilo que concebe o texto e o social. Ressaltamos, entretanto, que a autora não está filiada a $\mathrm{AD}$ pecheutiana.

Defendemos que o sujeito pode romper com os sentidos tidos como dominantes e que deve ter o direito à argumentação ${ }^{2}$. Portanto, com base na $\mathrm{AD}$ francesa de linha pecheutiana "Consideramos que argumentar é uma arte, em duplo sentido, isto é, tanto como a capacidade criadora do sujeito de colocar em prática uma ideia, quanto no sentido de o sujeito fazer algo com o intuito de provocação, de ir contra os padrões aceitos pelas instituições sociais" (PACÍFICO, 2002, p. 44). Argumentar é uma arte não apenas porque valoriza a capacidade criadora do sujeito, mas também, porque possibilita a criação de sentidos provocadores, que não são aceitos nos AIE.

Pacífico (2002, p. 47) assegura que "só haverá argumentação quando não houver consenso" e, de acordo com Plantin (2011, p. 18), a argumentação é "uma forma de interação problematizante formada de intervenções orientadas por uma questão". Nossa proposta é expor o sujeito-aluno à multiplicidade de sentidos sobre cotas raciais em universidades públicas brasileiras, e queremos interpretar o posicionamento do sujeitoaluno acerca dessa questão. Defendemos que as estratégias argumentativas "só se manifestam à medida que a própria organização da língua é condicionada por essa necessidade de agir sobre outrem” (MAINGUENEAU, 1997, p. 160).

Pensamos, então, quais sujeitos seriam capazes de responder nossos questionamentos e elegemos o sujeito-aluno de escolas públicas do interior de São Paulo, visto que eles, também, fazem parte de um grupo favorecido pelas cotas e que esse espaço deve ser o palco da argumentação e da reflexão sobre a sociedade.

\footnotetext{
${ }^{2}$ A partir do texto do texto Antônio Cândido (1995), "O direito à Literatura", acreditamos que o sujeito deve ter direito à argumentação, ou seja, o sujeito deve exercer a argumentação na sociedade sem que seja silenciado.
} 
Visamos analisar a escrita dos sujeitos-alunos de um texto dissertativoargumentativo que tem em sua essência a argumentação e beneficia o surgimento de sentidos polissêmicos. Conforme Tfouni (1995), a escrita é um produto cultural vinculado com o social, é por meio dela que teremos elementos que mostram um recorte do social, pois:

Se a escrita está associada, desde suas origens [...], ao jogo de dominação/poder, participação/exclusão que caracteriza ideologicamente as relações sociais, ela também pode ser associada ao desenvolvimento social, cognitivo e cultural dos povos, assim como a mudanças profundas nos hábitos comunicativos (TFOUNI, 1995. p. $13)$.

Concordamos com Tfouni (1995) que reconhecer que a escrita está relacionada a práticas de dominação e de poder, bem como de participação e de exclusão de um sujeito que vive em uma comunidade letrada. Por outro lado, a escrita está associada ao desenvolvimento dos povos, pois promove a mudança de hábitos comunicativos. Além disso, sabemos que "sujeito e sentido se constroem junto com o texto, em determinado contexto sócio-histórico" (PACÍFICO, 2002, p. 16) e devido a essa "construção" citada por Pacífico, explicitaremos as condições de produção para os textos desses sujeitos, a fim de termos análises representativas e articuladas com o ideológico e o social, porque "o elo que liga as significações de um texto as suas condições sócio-históricas não é secundário, mas constitutivo das próprias significações” (PÊCHEUX, 1971, p. 147).

Para a análise da produção dos sujeitos escolhidos, escolhemos o texto dissertativo-argumentativo. Esse gênero textual é muito representativo, já que, quando o sujeito precisa defender um posicionamento, ele deve, necessariamente, considerar o outro e as relações que são estabelecidas: "o outro nos constitui assim como o outro constitui o nosso discurso". (CORACINI, 2003, p. 201). Ao produzir um texto, o sujeito já pode considerar seu futuro leitor e tecer antecipações em relação a isso.

para argumentar o sujeito precisa ter um ponto de vista formado e certo conhecimento sobre o objeto discursivo, como é que o mesmo sujeito pode construir "seu" ponto de vista sobre um objeto se ele não tem acesso ao arquivo, se a escola (ensino fundamental e médio) não lhe dá meios para realizar pesquisas, para investigar os discursos acordes e discordes sobre determinado tema? (PACÍFICO, 2002, p. 54) 
Pacífico (2002) defende que o sujeito-aluno deve poder disputar o objeto discursivo e para tal ele carece de ter acesso ao arquivo, para poder construir um discurso polissêmico e argumentativo. A autora questiona se o AIE escolar possibilita esse acesso ao arquivo com o intuito de promover as práticas discursivas em sala de aula e afirma que "argumentar pressupõe considerar o outro, considerar a interação e a reação do sujeito diante de propostas e possibilidades que lhe são apresentadas. Implica, ainda, a possibilidade de discussão dos interlocutores frente ao objeto discursivo" (PACÍFICO, 2002, p. 45).

A argumentação é primordial, pois possibilita ao sujeito o questionamento e o posicionamento sobre aspectos relativos a sua comunidade e suas leis (por exemplo, as políticas afirmativas com recorte social) que norteiam a sociedade. Diante da compreensão e da utilização da argumentação, é possível propiciar uma ação política, então, defendemos prática desse conhecimento na escola "contribui para o exercício da democracia, ao colaborar com a formação de cidadãos aptos ao debate da coisa pública." (ZOPPI-FONTANA, 2010, p.184).

A classe dominante perpetua o seu poder por meio do discurso e pela ideologia presente nele, mas o sujeito pode desenvolver sua capacidade de leitura e encontrar brechas nesse discurso para que a manutenção dos sentidos dominantes não permaneça. De acordo com Pacífico (2002), argumentar é levar o outro a crer naquilo que se diz, pois a argumentação é um elemento primordial na vida do sujeito e "está relacionada à relação de poder que se estabelece, em determinado momento, entre as classes sociais, isto é, sempre haverá quem argumente e quem "é argumentado" (PACÍFICO, 2002, p. 43). Os AIE possuem essa relação de poder na sociedade, são aqueles que argumentam, especialmente a escola e a mídia, isso porque por meio da aparente neutralidade, a população é frequentemente "argumentada" visto que esses AIE levam muitas pessoas a acreditarem naquilo que eles enunciam, sem que haja espaço para o discurso polêmico.

Em suma, consideramos a interpelação do sujeito por meio da ideologia como um aspecto central da teoria da $\mathrm{AD}$, visto que ele está inserido em uma FD que possibilita a produção de enunciados com determinados efeitos de sentido, considerando a presença do interdiscurso, da memória discursiva e do arquivo. O sujeito-aluno está inserido no AIE escolar e esse espaço, muitas vezes, valoriza os sentidos parafrásticos em detrimento dos sentidos polissêmicos. Diante de uma proposta de redação que reclama por argumentação, será que esse sujeito-aluno consegue reconhecer o texto 
argumentativo como um recurso que possibilita rompimento dos sentidos cristalizados? O sujeito-aluno consegue assumir a responsabilidade pelo seu dizer? Em que medida esse AIE escolar dá condições para que a polissemia apareça? Os textos permanecem na ordem do repetível sem apresentar deslizamentos? Precisamos responder a essas questões para refletir sobre a verdadeira condição dos discursos dirigidos aos nossos alunos da escola brasileira.

O capítulo 2 ressalta as discussões sobre as cotas raciais em universidades públicas brasileiras por meio do discurso oficial (leis). Visamos, não somente a mostrar uma revisão bibliográfica sobre o tema, mas, também, apresentar uma análise discursiva sobre o discurso jurídico, elemento que está presente nos discursos dos sujeitos-alunos. 


\title{
2. O DISCURSO OFICIAL SOBRE AS COTAS RACIAIS
}

\author{
Hoje você é quem manda \\ Falou, tá falado \\ Não tem discussão \\ A minha gente hoje anda \\ Falando de lado \\ E olhando pro chão, viu [...] \\ Apesar de você \\ Amanhã há de ser \\ Outro dia [...]
}

(HOLANDA, 1970)

Este capítulo busca conceituar as políticas afirmativas com recorte racial (e as cotas) de modo a introduzirmos a temática que abordamos nos textos dissertativoargumentativos, produzidos pelos sujeitos-alunos, analisados no capítulo 4. Além disso, analisamos o discurso jurídico produzido na sociedade contemporânea, sobre essa questão por meio da leitura da Lei $n^{\circ}$ 12.711, que viabiliza a reserva de vagas para afrodescendentes em cursos de graduação, em universidades federais.

De modo geral, a pesquisa científica sobre cotas raciais está vinculada aos estudos históricos e sociológicos sobre as questões raciais. Valorizamos essas bases epistemológicas, todavia, nosso foco é o sujeito (histórico, ideológico e social) e o seu discurso. Pêcheux (1997) concebe a língua com a sua materialidade significante dotada de historicidade:

Todavia, essa materialidade histórico-linguística proposta por Pêcheux é distinta daquela concebida pelos sociólogos, pois para estes pensadores as palavras são habitadas pela história, isto é, as palavras, na sua concepção, são instrumentos que veiculam valores ideológicos. (BARONAS; AGUIAR, 2009, p. 167).

Pêcheux (1997) propõe o estudo da materialidade histórico-linguística do discurso, mas os trabalhos da $\mathrm{AD}$ podem ser enriquecidos pelo diálogo com outras filiações epistemológicas, pois "não há separação entre a língua, o sujeito e a história" (SCHONS; MITTMANN, 2009, p. 295), de tal forma que é pertinente utilizar os estudos e conceitos linguísticos para respondermos questões sociais, uma vez que

é no estabelecimento de relação entre diferentes áreas que se enriquecem as discussões teóricas e metodológicas, não só no interior das Letras como também na relação que se estabelece entre as Letras e 
as outras Ciências de Formação Social, como é o caso da Filosofia e da Sociologia, por exemplo (SILVEIRA, 2000, p. 121).

Silveira (2000) nos mostra que a relação entre distintas áreas do conhecimento possibilitam ricas discussões e pode apontar para possíveis soluções para problemáticas sociais.

Visando a problematizar as questões sociais, escolhemos como tema as cotas raciais. A partir dessa escolha, nós nos indagamos: quais são os sentidos possíveis para a palavra cota? Notamos que aqueles que têm, por uma imposição jurídica, o direito às cotas não possuem, predominantemente, direito ou acesso ao todo presente nas políticas universalizantes. Reconhecemos que no século $\mathrm{XX}$ não era comum encontrar um afrodescendente na faculdade; entretanto, interpretamos que o fato de haver a cota racial possibilita a circulação de uma FD possível, na contemporaneidade. Assim, faz-se necessário analisar quais sentidos circulam sobre as cotas raciais na escola. $\mathrm{O}$ assunto tem sido debatido nas últimas décadas, especialmente, a partir da implementação da lei, que inscreve uma nova discursividade: "um tema pode emergir aqui ou ali, pode ser caracterizado dessa ou daquela forma, mas é nas relações que se estabelecem entre esses lugares, entre diferentes discursos, que vão surgindo os sentidos" (SILVEIRA, 2000, p. 122). De acordo com Silveira (2000), é por meio das relações criadas entre lugares e distintos discursos que há surgimento dos sentidos e esses sentidos merecem análises.

Há uma representação imaginária e simbólica ao encontrar o afrodescendente na universidade pública brasileira, espaço em que não há (e não houve) a predominância dele. A política de cotas fortificou a discussão acerca dessa questão bem como movimentou sentidos de aceitação de que ainda há preconceito racial direcionado aos afrodescendentes na sociedade brasileira e de que mudanças são imprescindíveis:

Reconhecemos que o racismo ainda é um problema a ser enfrentado e que, nessa matéria, assim como em tudo que diz respeito à garantia de direitos humanos, é fundamental o engajamento de toda a sociedade brasileira, dos empresários e de todos aqueles que têm a possibilidade de estimular a diversidade nos ambientes de trabalho, de promover políticas de promoção de igualdade e inclusão, procurando assegurar oportunidades mais equitativas aos que, historicamente, são vítimas de discriminação. (PNDH, 2010, p. 263) 
O PNDH (Plano Nacional dos Direitos Humanos) também reconhece a existência do racismo e defende que a sociedade pode contribuir para garantir os direitos humanos dos afrodescendentes e postula que as políticas de promoção da igualdade e inclusão devem proporcionar condições igualitárias e caracteriza o afrodescendente como, historicamente, vítima de discriminação. Sentidos parafrásticos relacionados à defesa de condições igualitárias bem como à caracterização da história do afrodescendente como vítima de discriminação podem ser encontrados em alguns discursos dos sujeitos-alunos, tais como:

\section{Recorte 1}

Contudo, todos os humanos são iguais, logo para conquistarem a vaga, o primordial é a meritocracia.(A cor do conhecimento).

\section{Recorte 2}

[...] tais cotas foram criadas com o intuito de amenizar a dívida histórica do Brasil com essas etnias e as diferenças sociais em tais. (Cotas: um meio de oportunidade aos afrodescendentes).

Os recortes 1 e 2 são analisados no capítulo 4, todavia há algumas marcas e indícios presentes nos textos que já devem ser apontados. O trecho do PNDH (2010), Programa do Governo Federal que teve como um de seus objetivos o desenvolvimento de mecanismos de controle social das políticas públicas de Direitos Humanos, afirmou que a sociedade deve estimular a diversidade e "promover políticas de promoção de igualdade e inclusão" (PNDH, 2010, p. 263, grifo nosso) e se vale de expressões que indicam totalidade, como, por exemplo, "toda sociedade" e "todo aquele". Paralelamente o recorte 1, do texto intitulado "A cor do conhecimento", postula que “todos os humanos são iguais". Além disso, o Programa do Governo Federal defende que se deve "assegurar oportunidades mais equitativas aos que, historicamente, são vítimas de discriminação" (PNDH, 2010, p. 263), ou seja, o texto se refere aos afrodescendentes como historicamente vítimas de discriminação e a dissertação "Cotas: um meio de oportunidade aos afrodescendentes" atesta que "[...] tais cotas foram criadas com o intuito de amenizar a dívida histórica do Brasil”. Até o momento notamos que é possível estabelecer relações entre o discurso governamental e os textos dos sujeitosalunos, especialmente, no que se refere ao sentido de inclusão presente na palavra 
"todos" e nos argumentos favoráveis às cotas raciais que fazem referências ao passado histórico dos afrodescendentes no Brasil, ou seja, o discurso governamental é uma das memórias do dizer dos discentes.

Concordamos que "A subordinação explícita do homem ao discurso religioso dá lugar à subordinação, menos explícita, do homem às leis: com seus direitos e deveres." (ORLANDI, 2001, p. 51), uma vez que na Idade Média o homem era subordinado à Igreja e a suas orientações de conduta. A partir da constituição do Estado Moderno, notamos a constante interpelação do discurso jurídico. Pêcheux (1988) ao analisar o discurso jurídico assevera que:

O futuro do subjuntivo da lei jurídica 'aquele que causar um dano...' ( e a lei sempre encontra 'um jeito de agarrar alguém', uma 'singularidade' à qual aplicar sua 'universalidade') produz sob a forma do sujeito de direito. Quando o sujeito ideológico que o reduplica, ele é interpelado- constituído sob a evidência da constatação que veicula e mascara a 'norma' identificadora. (PÊCHEUX, 1988, p. 145-146, grifo do autor).

Os direitos concedidos às denominadas minorias aparecem como o resultado do reconhecimento de que há uma segmentação social e que é necessária a aplicação de políticas públicas para alguns grupos sociais, isso ocorre porque a sociedade, na prática, não pode ser interpretada como igual e libertária, sendo assim "os direitos são respostas às faltas produzidas pelo próprio sistema (o direito é o direito de remediar a falta)" (ORLANDI, 2011, p. 207). As políticas afirmativas com recorte racial surgem para sanar as diferenças educacionais e sociais existentes entre brancos e afrodescendentes, mas também surgem para salientar que essas diferenças ainda existem, porque o sujeito "ao reivindicar a igualdade, não estará apenas ocultando novas diferenças, mas explicitando-as" (ORLANDI, 2011, p. 207). Ressaltamos que essa reivindicação de igualdade mencionada por Orlandi (2011) pode estar relacionada às reivindicações apresentadas pelo Movimento Negro e essa compreensão se faz essencial pelo fato de as "ações afirmativas e as cotas constituírem uma das reivindicações dos integrantes dessas organizações. Atualmente, "o Movimento Negro [...] se constitui como principal representante no posicionamento discursivo pró-cotas". (OLIVEIRA, 2012, p. 28, grifo do autor). Assim, as cotas representam uma constatação das condições desiguais na sociedade brasileira e são resultado de lutas do Movimento Negro Nacional. 
O discurso jurídico é importante na contemporaneidade e mostra a força do discurso de igualdade. Reiteramos que a partir da constituição do Estado Moderno há a presença de um discurso igualitário; porém, o Estado é sustentado por relações desiguais. O que mostra que o discurso de igualdade, muitas vezes, é responsável por mascarar as diferenças em nossa sociedade, que é constituída pelo capitalismo e que se vale também das práticas jurídicas:

Como o Estado capitalista funciona pelo jurídico, esta forma sujeito funciona com seus direitos e deveres. O Estado, por sua vez, cumpre o seu modo de funcionamento, capitalista, individualizando o sujeito pela prática de suas Instituições e Discursos. (ORLANDI, 2010, p. 3).

Orlandi (2010) ressalta que o Estado capitalista opera por meio do jurídico que tem em sua base o estabelecimento de direitos e deveres. O Estado individualiza o sujeito por meio de suas Instituições e por meio de seus discursos. Defendemos que essas instituições interpelam o indivíduo em sujeito, já que ele sofre interpelações dos aparelhos ideológicos e do aparelho repressivo: "a interpelação é, simultaneamente, ideológica $e$ jurídica, isto é, que ela não se efetua na esfera fechada e vazia do 'cultural', mas na imbricação dos aparelhos ideológicos e do aparelho repressivo (jurídicopolítico) de Estado." (PÊCHEUX, 1988, p. 242). O aparelho repressivo representado pelo jurídico-político age por meio da repressão (e também pela ideologia jurídica) e o AIE escolar age por meio da ideologia.

A escola, no caso a universidade, foi a esfera social escolhida pelo Estado para minimização das desigualdades, considerando que "A educação é um campo com sequelas profundas de racismo, para não dizer o veículo de comunicação da ideologia branca" (ROCHA, 1998, p. 56). Por um lado, concordamos com Rocha (1998), a educação apresenta sequelas do racismo presentes na sociedade. Por outro, sequencialmente, o autor afirma que a escola tem o papel de veicular a ideologia branca, entretanto, discordamos de que haja uma "ideologia branca", visto que nossos estudos em relação à ideologia estão em consonância com Althusser (1971), que entende a escola como um AIE: 
Porque, se é verdade que os AIE representam a forma na qual a ideologia da classe dominante deve necessariamente realizar-se, a forma com a qual a ideologia da classe dominada deve necessariamente medir-se e afrontar-se, as ideologias não "nascem" nos AIE, mas das classes sociais envolvidas na luta de classes: das suas condições de existência, das suas práticas, das suas experiências de luta, etc. (ALTHUSSER, 1971, p. 120121).

Althusser (1971) afirma que a ideologia nasce nas classes sociais envolvidas na luta de classes. O espaço no qual queremos problematizar sobre as cotas raciais é a escola que, muitas vezes, mostra-se como reprodutora de preconceitos, pois “desqualifica as variedades linguísticas usadas pelos alunos e alunas subalternizadas, afrodescendentes e indígenas, condenados à pobreza e ao silêncio" (GARCIA, 2008, p. 12). Garcia (2008) acusa a escola de reproduzir as desigualdades que estão presentes na sociedade por meio de suas práticas e de seus discursos que desprestigiam as variedades linguísticas dissonantes na norma padrão da Língua Portuguesa. Em outras palavras, observamos que a cultura de alguns grupos é, frequentemente, negligenciada e o preconceito se mostra presente no Brasil, sobretudo, quando se refere aos fatores econômicos e ao poder aquisitivo dos afrodescendentes, que, muitas vezes, é limitado. A citação abaixo mostra situações de desigualdade e apresenta questionamentos relevantes:

Se analisarmos os indicadores educacionais vamos melhor entender o que vem acontecendo com os afrodescendentes no Brasil. No Brasil a população analfabeta funcional com mais de 15 anos é de 30,5\%; deste total, entre os brancos o percentual é de $22,7 \%$, enquanto que os afrodescendentes é de $41,7 \%$, chegando a $57 \%$ no Nordeste.

Será que ainda precisamos perguntar por que há tantos afrodescendentes entre os pobres e tão poucos afrodescendentes na classe média ascendente. [...]

E a outra pergunta que sai da boca, ainda que não queira: E o que faz o sistema educacional brasileiro face a esta situação? E nós, o que estamos fazendo? (GARCIA, 2008, p. 16)

Garcia (2008) relaciona o fato de haver tantos afrodescendentes com baixo poder aquisitivo aos índices de analfabetismo funcional que atingem grande parte dessa 
população brasileira. Além disso, a autora questiona sobre quais medidas estão sendo tomadas pelo sistema educacional para alterar essa situação e ter uma sociedade sem essas mazelas sociais. Sobre as ações práticas para sanar o problema a pesquisadora provoca: "E nós, o que estamos fazendo?”. Nós precisamos estudar e compreender academicamente a desigualdade educacional e propor medidas educacionais para que a instituição escolar não seja uma reprodutora de preconceitos e especialmente, enquanto professores, melhorarmos nossas aulas. De fato, muitos dos afrodescendentes, ainda, no século XXI, são desfavorecidos economicamente, especialmente, nas regiões metropolitanas do país:

Atualmente, portanto, o Poder Judiciário brasileiro vem lidando com três vertentes quando do tratamento da temática envolvendo a população negra e os seus direitos coletivos: i) a efetiva aplicabilidade em termos técnicos, éticos e políticos da legislação que criminaliza o racismo; ii) as interpretações sobre como os direitos coletivos dos quilombolas, previstos na Constituição de 1988, serão efetivamente garantidos; e iii) a constitucionalidade das ações afirmativas (PAIXÃO, 2010, p. 17).

Paixão (2010) apresenta as três áreas de atuação do Poder Judiciário Nacional que visam a atender os direitos da população afrodescendente, dentre elas, ele pondera sobre a constitucionalidade das políticas afirmativas. Essas postulações acerca da posição econômica dos afrodescendentes são significativas para entendermos por quais motivos esse grupo é beneficiado pelas cotas.

Apesar de reconhecermos a polêmica que esse assunto provoca, defendemos que um país não pode desenvolver-se, realmente, se possui em seu âmago a desigualdade social; logo, essa realidade precisa ser alterada e dessa forma surge outra indagação: as cotas raciais podem alterar a realidade de marginalização dos afrodescendentes brasileiros ou outras medidas devem ser viabilizadas? As cotas raciais estão alterando a representatividade dos afrodescendentes nas universidades federais brasileiras: a Universidade de Brasília (UnB), uma das pioneiras em criar políticas de igualdade racial, por exemplo, apresenta resultados satisfatórios com a adoção dessa política. 


\section{1 Políticas afirmativas de recorte racial: uma temática que reclama argumentação}

Nossos estudos refletem sobre o posicionamento argumentativo dos sujeitosalunos acerca das cotas raciais. Dessa forma, analisamos como eles se posicionam sobre a temática proposta, pois para nós, assim como para Amossy (2011, p. 133), “é importante conhecer a essência do que é dito ou escrito em uma determinada sociedade sobre o tema posto em questão.”. Defendemos que a escola deve proporcionar ao sujeito-aluno um espaço para a disputa de sentidos e para possibilidade do discurso polissêmico, ou seja, ele deve ter o direito à argumentação bem como a outros direitos humanos, visto que a "argumentação também deve ser entendia como um direito humano, direito este que deve ser exercido no contexto escolar, a fim de que os sujeitosalunos pratiquem a argumentação, dentro e fora da escola, como uma prática social" (PACÍFICO, 2016, p. 192). Além disso, a analista do discurso de matriz pecheutiana reitera a importância da argumentação no contexto escolar: "a argumentação deve ser legitimada na instituição escolar para que o sujeito, exercendo essa prática discursiva, sinta-se no direito de tomar a palavra, e mergulhar no fio discursivo e posicionar-se acerca dos sentidos colocados em circulação, na sociedade. (PACÍFICO, 2016, p. 192). Concordamos com Pacífico (2016) ao interpretar a argumentação como um direito do cidadão e não apenas como um estudo empírico presente nos manuais didáticos de Língua Portuguesa. Nosso estudo visa a contribuir para que os sujeitos-alunos possam se valer do discurso para argumentarem sobre essa temática que possui relevância em suas vidas. Diante dos nossos objetivos, é necessário conceituarmos e refletirmos sobre algumas questões vinculadas às cotas.

Entendemos a ação afirmativa como:

[...] incremento da contratação e promoção de membros de grupos discriminados no emprego e na educação por via de metas, cotas, bônus ou fundos de estímulo; bolsas de estudo; empréstimos e preferência em contratos públicos; determinação de metas ou cotas mínimas de participação na mídia, na política e outros âmbitos; reparações financeiras; distribuição de terras e habitação; medidas de proteção a estilos de vida ameaçados; e políticas de valorização identitária (FEREZ JUNIOR; DAFLON; BARBABEL, 2013, p. 4). 
Os autores apresentam diversas medidas destinadas para alguns grupos que visam a minimizar as desigualdades. No Brasil, as cotas raciais foram utilizadas, predominantemente, em universidades federais. Salientamos que as cotas para afrodescendentes estão inseridas no grupo de ações e políticas amplas que não são originarias do Brasil: as ações afirmativas "surgiram nos Estados Unidos como fruto da luta de negros americanos exigindo e pressionando os governantes para que se findasse o regime de segregação racial existente, principalmente, nos estados do sul do país" (OLIVEIRA, 2012, p. 30). A luta do Movimento Negro americano é reconhecida mundialmente e foi indispensável para o estabelecimento e fortalecimento das lutas pelos direitos civis do afrodescendente no Brasil, sobretudo a partir da década de 1980.

Em relação às políticas públicas ressaltamos que as políticas universalizantes não conseguem atingir a todos os grupos, por sua vez, as afirmativas buscam um direito negado, promovendo um grupo, historicamente, renegado socialmente. Já as políticas repressivas têm o intuito, sobretudo, punir comportamentos inadequados ${ }^{3}$. Há, também, as políticas valorativas, que visam a valorizar a história de um povo não prestigiada nos meios escolares. Como exemplo desse tipo de política, citamos a Lei $\mathrm{n}^{\circ} 10.639$, de 9 de janeiro de 2003, que tornou obrigatório o ensino de história e cultura afro-brasileira nas escolas públicas e privadas no ensino fundamental e médio. A partir de então, hipoteticamente, todas as escolas apresentam essa temática em seu currículo escolar. Vejamos o discurso público (Anexo A):

Art. 26-A. Nos estabelecimentos de ensino fundamental e médio, oficiais e particulares, torna-se obrigatório o ensino sobre História e Cultura Afro-Brasileira.

$\S 1$ o O conteúdo programático a que se refere o caput deste artigo incluirá o estudo da História da África e dos Africanos, a luta dos negros no Brasil, a cultura negra brasileira e o negro na formação da sociedade nacional, resgatando a contribuição do povo negro nas áreas social, econômica e política pertinentes à História do Brasil.

$\S 2$ o Os conteúdos referentes à História e Cultura Afro-Brasileira serão ministrados no âmbito de todo o currículo escolar, em especial nas áreas de Educação Artística e de Literatura e História Brasileiras.

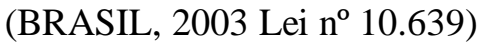

Percebemos o peso do juridismo que impõe, muitas vezes, sem ampla discussão social, o que pode e deve ser ensinado nos AIE, o que mostra a relação constante desses

\footnotetext{
${ }^{3}$ Como exemplo, citamos o fato ocorrido com a torcida do clube de futebol Grêmio-RS, no ano de 2014, em que houve punição a torcedores e ao clube por proferirem discursos racistas contra o goleiro Aranha, do time adversário, Santos, durante uma partida de futebol.
} 
grandes aparelhos ideológicos. A lei acima propaga a cultura afro-brasileira nas instituições escolares, uma vez que os costumes, os dialetos (ou línguas) e as religiões desse grupo foram desprestigiados na constituição da cultura oficial brasileira. A diretriz governamental postula que se deve estudar a temática "resgatando a contribuição do povo negro nas áreas social, econômica e políticas pertinentes à História do Brasil." Entretanto, não há a apresentação de meios concretos para a implementação da lei, ou, se/como/quando, vai fornecer os recursos necessários para que isso ocorra e nem faz menção à questão linguística.

A fim de mostrarmos as reverberações acerca da lei, conforme a reportagem intitulada "Conteúdo sobre África ainda é escasso", de Guilherme Soares Dias (publicada originalmente em O Estado de São Paulo - 21/11/2013) e publicada posteriormente no site da USP há uma baixa aplicabilidade da lei:

Dez anos após ser sancionada, a Lei 10.639 - que torna obrigatório o ensino da história africana e afro-brasileira - ainda é aplicada de maneira tímida na maioria das escolas brasileiras. A implementação de conteúdos de forma transversal - em todas as disciplinas - ocorre de forma lenta em todas as redes escolares, mas as municipais (com $46 \%$ das escolas) e as estaduais (com 39\%) estão na frente das particulares $(6 \%)$. Os dados fazem parte de uma pesquisa do Centro de Estudos das Relações do Trabalho e Desigualdades (Ceert), em parceria com o Ministério da Educação e a Unesco. Foram compiladas 2,3 mil iniciativas de utilização do conteúdo previsto.

(DIAS, 2013)

De acordo com a pesquisa realizada pelo Centro de Estudos das Relações do Trabalho e Desigualdades (Ceert), que foi na citada na reportagem acima, a Lei 10.639 não está é plenamente aplicada na maioria das instituições escolares brasileiras. O texto de Dias (2013) ressalta que o objetivo da norma não é apenas resolver o problema racial ou atender as demandas do Movimento Negro. De acordo com a pesquisa, as escolas municipais (46\%) e as estaduais (39\%) estão valorizando mais a lei em detrimento das escolas privadas (6\%). Defendemos que para termos cidadãos mais conscientes da diversidade étnica nacional e conhecedores das culturas basilares de nosso país é necessário que as instituições particulares também alterem o seu currículo, seus materiais didáticos, suas bibliotecas e especialmente as suas práticas. Tais alterações solicitadas por essa política valorativa são imprescindíveis porque, de modo geral, na rede particular de ensino está a maior parte da população branca que também tem o 
direito de aprender mais sobre a literatura, cultura, história, línguas e costumes afrobrasileiros e ser beneficiado com esse conhecimento.

Ainda acerca do discurso jurídico, sustentamos que a concepção do sujeito de direito (PÊCHEUX, 1988) é importante para entendermos como os sentidos presentes nas leis deslizam. A Lei de $\mathrm{n}^{\mathrm{o}}$ 12.711, de agosto de 2012 (Anexo B) foi a responsável por ampliar a presença das cotas em universidades federais. Vejamos suas indicações.

Art. $1^{\underline{0}}$ As instituições federais de educação superior vinculadas ao Ministério da Educação reservarão, em cada concurso seletivo para ingresso nos cursos de graduação, por curso e turno, no mínimo $50 \%$ (cinquenta por cento) de suas vagas para estudantes que tenham cursado integralmente o ensino médio em escolas públicas.

Parágrafo único. No preenchimento das vagas de que trata o caput deste artigo, $50 \%$ (cinquenta por cento) deverão ser reservados aos estudantes oriundos de famílias com renda igual ou inferior a 1,5 salário-mínimo (um salário-mínimo e meio) per capita.

Art. $3^{\circ}$ Em cada instituição federal de ensino superior, as vagas de que trata o art. $1^{\mathrm{o}}$ desta Lei serão preenchidas, por curso e turno, por autodeclarados pretos, pardos e indígenas, em proporção no mínimo igual à de pretos, pardos e indígenas na população da unidade da Federação onde está.

Art. $5^{\circ}$ Em cada instituição federal de ensino técnico de nível médio, as vagas de que trata o art. $4^{\circ}$ desta Lei serão preenchidas, por curso e turno, por autodeclarados pretos, pardos e indígenas, em proporção no mínimo igual à de pretos, pardos e indígenas na população da unidade da Federação onde está instalada a instituição, segundo o último censo do Instituto Brasileiro de Geografia e Estatística (IBGE).

Art. $8^{\circ}$ As instituições de que trata 0 art. $1^{\underline{0}}$ desta Lei deverão implementar, no mínimo, $25 \%$ (vinte e cinco por cento) da reserva de vagas prevista nesta Lei, a cada ano, e terão o prazo máximo de 4 (quatro) anos, a partir da data de sua publicação, para o cumprimento integral do disposto nesta Lei.

Nesse recorte da lei devemos nos atentar para os efeitos de sentido possíveis a partir do modo pelo qual os seguintes verbos são utilizados: "reservarão", "deverão ser reservados", "serão preenchidas" e "deverão implementar". Observamos que há a formação dos tempos verbais simples e compostos que denotam ações a serem realizadas no futuro e podem também indicar um valor imperativo, especialmente na formulação "As instituições de que trata o art. 1o desta Lei deverão implementar, no mínimo, 25\% (vinte e cinco por cento) da reserva de vagas prevista nesta Lei [...]”. Além disso, a lei poderia ter mais indicações de como essa reserva de vagas seria de fato implementada. Reconhecemos, então, a importância da análise discursiva dessa lei para a compreensão dos sentidos que circulam sobre as cotas raciais. 
De acordo com Pêcheux (1997, p.57), arquivo é o "campo de documentos pertinentes e disponíveis sobre uma questão" e interpretamos a lei como um arquivo devido a sua institucionalidade e como representação do discurso jurídico. O discurso presente nas leis 10.639 e 12.711, ambas promulgadas no século XXI, remete-nos a publicação da Lei no 3.353, de 13 de maio de 1888 e assinada pela Princesa Isabel. Por meio da leitura da Lei Áurea, é possível notar o funcionamento do discurso jurídico no século XIX. Essa lei possui apenas dois artigos: “Art. $1^{\circ}$ É declarada extinta desde a data desta Lei a escravidão no Brasil. Art. $2^{\circ}$ Revogam-se as disposições em contrário." Nessa lei também não há a menção de como ser humano cruelmente escravizado seria inserido na sociedade do trabalho livre. Sabe-se que "Não podemos negar que muitos sentidos são silenciados no texto dos documentos oficiais" (ZONATTO; PACÍFICO; ROMÃO, 2009, p. 421) e alguns dos sentidos possivelmente silenciados pela Lei Áurea são mostrados no livro "A integração do negro na sociedade de classes", do sociólogo Florestan Fernandes:

Os senhores foram eximidos da responsabilidade pela manutenção e segurança dos libertos, sem que o Estado, a Igreja ou qualquer outra instituição assumisse encargos especiais, que tivessem por objeto prepará-los para o novo regime de organização da vida e do trabalho. [...] Essas facetas da situação [...] imprimiram à Abolição o caráter de uma espoliação extrema e cruel. (FERNANDES, 1978, p. 28).

Fernandes (1978) interpreta a abolição da escravidão no Brasil como uma espoliação extrema e cruel visto que as instituições sociais não assumiram a responsabilidade de proporcionar condições dignas de vida aos "libertos". Concordamos com o sociólogo e ainda percebemos as consequências dessa lei que não demonstrou preocupação com o afrodescendente no Brasil. Tal marginalização está, ainda hoje, presente em nosso país: os afrodescendentes (em sua maioria) continuam às margens do mercado de trabalho formal detentor de prestigio social e das universidades públicas brasileiras.

Acerca da Lei 12.711, o primeiro artigo assevera que as instituições federais de educação superior devem reservar no mínimo $50 \%$ de suas vagas para estudantes que tenham cursado integralmente o Ensino Médio em escolas públicas. O discurso jurídico é relevante para o sujeito-aluno, pois ele pode acessar o arquivo e escrever textos que dialogam com a lei, como vemos no recorte 3 : 


\section{Recorte 3}

A história dos negros são comoventes, e mostram que querem mudar de vida, e por isso, estudam e batalham para entrar em uma universidade, mas precisamos dos $50 \%$ para isso tornar ainda mais fácil. (Sem título).

No recorte 1, o sujeito-aluno citou um elemento da lei em seu texto e se posicionou pessoalmente sobre o tema por meio da forma verbal em primeira pessoa ("precisamos") indicando que, possivelmente, o sujeito será beneficiado pela política de cotas. Quando um sujeito tem acesso ao arquivo ele pode realizar gestos de interpretação ou ainda os sentidos podem migrar e circular no discurso do senso comum. Contudo, o estudo de Pacífico (2002, p. 155) aponta que "o sujeito tem acesso ao arquivo quando há o trabalho com a interpretação e não, apenas, com a leitura parafrástica dos textos") e é essa relação do sujeito com o arquivo que nossas análises tentarão compreender.

A Lei 12.711 foi a que mais proporcionou o questionamento sobre as políticas públicas afirmativas, de modo há pessoas que argumentaram que, com a presença desses grupos citados na lei na universidade pública (como, por exemplo o texto da revista Veja no Anexo E), a qualidade do ensino seria prejudicada, pois as universidades públicas abrigam a maior parte das pesquisas brasileiras. Em sentido oposto, os grupos de promoção da igualdade cultural e racial celebraram esse momento como uma importante vitória.

Apesar de essas medidas terem sido viabilizadas nas universidades federais, nas universidades estaduais de São Paulo a questão das cotas é menos incentivada. Assim, algumas das consideradas melhores universidades, como a USP e a Universidade Estadual de Campinas (UNICAMP) oferecem resistência às cotas. Por outro lado, uma das universidades pioneiras na utilização das políticas afirmativas foi a (UnB) que elaborou uma análise e rica em informações do sistema de cotas para afrodescendentes. Esses dados foram coletados do $2^{\circ}$ Semestre de 2004, até o $1^{\circ}$ Semestre de 2013, e apresentaram os seguintes resultados:

Os dados sistematizados pelo CESPE mostram que a decisão do CEPE da UnB de implementar as cotas para negros e indígenas a partir do $2^{\circ}$ semestre de 2004 foi uma medida justa e necessária para diminuir a desigualdade étnica e racial no ensino superior brasileiro. Essa histórica decisão, resultado de um processo de discussão iniciado em 
1999, foi pioneira em todo o país e pautou a discussão nacional sobre as cotas, tema que se tornou hoje uma política de Estado, como evidencia o projeto de Lei em trâmite no Congresso Nacional que reserva $20 \%$ das vagas no serviço público para negros (UNIVERSIDADE DE BRASÍLIA, 2013. p. 36).

A Universidade de Brasília defende a necessidade das cotas como meio para a diminuição da desigualdade étnica e racial no ensino superior e ressalta que a adoção dessa política não foi feita por meio de uma imposição institucional, porque foi implementada após a discussão na universidade. O pioneirismo da UnB proporcionou que, posteriormente, essa medida se tornasse uma política de Estado e a universidade mostra resultados satisfatórios ocorridos nesses últimos anos.

No Brasil, ainda não há um sólido conhecimento e problematização sobre o assunto que seja pautado em informações fundamentadas em dados, e isso ocorre, frequentemente, também, por causa da ineficiência da grande mídia: "Esta, com seus critérios próprios de noticiabilidade, produz representações fortemente enviesadas da realidade" (DAFLON; FEREZ JR; CAMPOS, 2013, p. 304). A mídia pode ser vista como um importante AIE e o seu discurso poderá ser percebido nos textos dos sujeitosalunos.

Acerca do modo como as vagas são reservadas, salientamos que autodeclaração é tida como critério principal para avalizar se alguém é considerado "negro" ou não; o que é levado em conta é, especificamente, a visão que o sujeito tem de si mesmo e como ele se caracteriza em relação à sua etnia, o que nos remete a questões vinculadas à identidade e ao reconhecimento. Porém, mesmo diante de tal questão, apenas seis universidades criaram comissões de verificação racial. Percebemos que a autodeclaração não está apenas ligada à questão social como acontece com os alunos de escolas públicas (critério essencialmente financeiro). Entretanto, o fato é que o propósito da política de cotas é incluir o afrodescendente na universidade, seja ele desfavorecido economicamente ou não.

O critério financeiro é menos criticado no Brasil para a destinação das cotas: "Nosso levantamento demonstra que os alunos egressos da escola pública despontam como os maiores alvos dessas políticas: 60 das 70 universidades com sistemas de cotas, bonificação ou acréscimo de vagas (85\%) visam a esse grupo" (DAFLON; FEREZ JR; CAMPOS, 2013, p. 309), ou seja, de acordo com os dados citados pelos autores, há uma preferência pela cota social, para egressos de escolas públicas, em detrimento do étnico- 
racial, o que pode provocar uma fragilização do debate a respeito da questão racial. Ademais, o critério de renda pode ser problemático, também, pois há candidatos que não têm condições de comprovar sua limitação financeira em função da situação de informalidade em que vivem, situação que os afasta ainda mais da universidade.

Portanto, defendemos que presença da questão racial nas leis e das discussões sobre o assunto é resultado da mobilização de diversos segmentos do Movimento Negro brasileiro e para compreendermos a circulação de sentidos sobre o tema devemos ler e compreender esses arquivos: "A leitura do arquivo deve ser antes de tudo um ato político no interior de um espaço de leitura polêmico, onde se produzem e se reproduzem discursos" (SILVEIRA, 2000, p. 124). Tornar a leitura do arquivo como um ato político por meio do espaço de leitura polêmico o qual possa produzir reproduzir discursos é o que propomos para os sujeitos-alunos. Sobre essa relação política, estudos de Schons e Mittmann apontam que:

Falar sobre a inclusão do político na linguagem significa buscar, de imediato não apenas estabelecer relação com os princípios de igualdade de direitos, mas também levar em conta a igualdade língua/nação. Todavia, antes de tudo, é preciso dizer que o político implica trabalho com dupla materialidade- a da língua e a da história. (SCHONS; MITTMANN, 2009, p. 302).

As autoras ponderam sobre a inclusão do político na linguagem que visa a considerar a igualdade língua/nação. O processo da leitura das leis deve sempre levar em conta a materialidade linguística e histórica citada por Pêcheux (1997), no início deste capítulo.

Tecemos aqui alguns apontamentos acerca das desigualdades sociais e, a partir disso, defendemos que AIE escolar pode e deve ser o espaço para a mudança da atual realidade. Nós, que também ocupamos a posição discursiva de professores da educação básica, asseguramos que podemos melhorar nossa prática docente cotidiana de modo a discursivizar o afrodescendente como um cidadão. Assim, na literatura brasileira e internacional (especialmente de países pertencentes ao continente africano) encontramos autores que retratam o afrodescendente no Brasil. Vejamos o fragmento do poema "O calhambola""4:

\footnotetext{
${ }^{4}$ Salientamos que calhambola era o nome dado aos moradores dos quilombos, hoje, usamos a palavra quilombola.
} 
Nasci livre, fizeram-me escravo;

Fui escravo, mas livre me fiz.

Negro, sim; mas o pulso do bravo

Não se amolda ás algemas servis!

Negra a pel, mas o sangue no peito,

Como o mar em tormentas desfeito,

Ferve, estúa, referve em canhões!

Negro, sim; mas é forte o meu braço,

Negros pés, mas que vencem o espaço,

Assolando, quase negros tufões!

(GALVÃO, 2007 [1898], p. 16)

O poema "O calhambola", do maranhense Trajano Galvão, possui o eu lírico que se denomina "negro" e essa identificação é relevante para as questões de identidade. Asseguramos que os sujeitos-alunos merecem conhecer e estudar o "O calhambola" e muitos outros poemas com essa temática.

De acordo com as reflexões apresentadas, sabemos que essa temática é polêmica e merece mais estudos, pois é algo que permeia a nossa sociedade. Além disso, defendemos que a lei deve ser problematizada nas escolas e discutida por aqueles sujeitos que serão diretamente afetados por essa política, uma vez que os sujeitos-alunos dessa etapa de ensino serão os mais afetados, pela lei, no que se refere ao vestibular. Assim, o capítulo 3 apresenta o nosso caminho a fim de problematizar as cotas em duas escolas públicas e mostra o nosso percurso metodológico, bem como quais foram as condições de produção encontradas para a constituição do corpus desta dissertação. 


\title{
3. O PERCURSO METODOLÓGICO
}

\author{
Caminante, no hay camino, \\ Se hace camino al andar. \\ Al andar se hace camino \\ y al volver la vista atrás \\ se ve la senda que nunca \\ se ha de volver a pisar. \\ Caminante no hay camino \\ Sino estellas en la mar...
}

(MACHADO, 1917)

Neste capítulo, mostraremos o caminho metodológico realizado nesta pesquisa. Para tanto, explicitamos as condições de produção encontradas para a constituição do corpus e a viabilização da elaboração dos textos dos sujeitos-alunos.

De acordo com Alvarenga (2003), a metodologia de uma pesquisa se mostra como algo primordial, pois ela "estuda, descreve e explica os métodos. A metodologia não procura soluções, mas escolhe as maneiras de encontrá-las, integrando os conhecimentos a respeito dos métodos em vigor nas diferentes disciplinas científicas ou filosóficas (ALVARENGA, 2003, p. 16).” A explicitação do caminho percorrido na pesquisa é primordial visto que um estudo com base nas teorias discursivas reconhece que não é possível alcançar a totalidade, pois o analista deve realizar escolhas e recortes para as análises dos dados. Partindo desses pressupostos, buscamos, então, organizar o nosso trabalho com o intuito de estabelecer uma forma ordenada de proceder ao longo de um caminho. Explicitamos o conjunto de processos ou fases empregadas em nossa investigação para compor este estudo.

Nossa abordagem é de cunho qualitativo, pois a abordagem qualitativa apresenta "uma metodologia de investigação que enfatiza a descrição, a indução, a teoria fundamentada e o estudo das percepções pessoais" (BOGDAN; BIKLEN, 1994). Essa abordagem reconhece a teoria de modo fundamentado e valoriza não os aspectos objetivos e lógicos, mas as percepções subjetivas que podem estar presentes nos estudos, ademais a pesquisa qualitativa "inclui as concepções teóricas de abordagem, o conjunto de técnicas que possibilitam a construção da realidade e o sopro divino do potencial criativo do investigador" (MINAYO, 2010, p. 16).

Já a abordagem quantitativa, segundo Cozby (2003), “enfatiza os dados estatísticos e utiliza os números obtidos como forma de compreender os fenômenos e variáveis estudadas". Esse método não coaduna nossa perspectiva teórica, isso porque 
ele privilegia aspectos positivistas em relação ao tratamento dos dados, o que pode propiciar resultados generalizantes:

Os fundamentos da pesquisa quantitativa nas ciências sociais são os próprios princípios positivistas clássicos segundo os quais: (a) o mundo social opera de acordo com leis causais; (b) o alicerce da ciência é a observação sensorial; (c) a realidade consiste em estruturas e instituições identificáveis enquanto dados brutos por um lado, crenças e valores por outro. Estas duas ordens são correlacionadas para fornecer generalizações e regularidades; (d) o que é real são os dados brutos considerados dados objetivos; valores e crenças são realidades subjetivas que só podem ser compreendidas através dos dados brutos (HUGHES, 1983, p. 42-63 apud MINAYO, 2008, p. 30).

Assim, a pesquisa quantitativa enfoca a objetividade. Os valores e as crenças dos sujeitos podem não ser valorizados no tratamento dos dados. Isso pode propiciar o apagamento de diversos elementos subjetivos que, para nós, são relevantes.

A respeito da constituição do corpus, não trabalhamos com um número elevado de textos dissertativo-argumentativos dos sujeitos-alunos a fim de fazermos uma análise gramatical dos mesmos, pois outros sentidos poderiam ser silenciados.

Segundo Minayo (2008) a AD é uma técnica de análise na pesquisa qualitativa. Estamos, então, erigindo uma pesquisa qualitativa que apresenta como método de tratamento de dados a teoria discursiva, responsável por guiar-nos para a compreensão de aspectos tanto linguísticos como extralinguísticos presentes no corpus.

No âmbito da $A D$, trabalhamos na perspectiva de linha francesa pecheutiana que é um campo teórico relevante para a educação, pois não se preocupa com o produto de um processo - com o resultado final encontrado em um texto; a $\mathrm{AD}$ valoriza o percurso de constituição do discurso e, consequentemente, de seus sentidos. Considerando essa definição, nosso estudo focaliza a relação do sujeito com a linguagem, com as marcas enunciativas e com o silêncio (ORLANDI, 2007), que, produz, também, sentidos.

Além disso, a $\mathrm{AD}$ se preocupa com o sujeito em seu caráter histórico, social e ideológico; ela valoriza traços essenciais que devem estar presentes na constituição do estudo, tais como "especificação de uma questão; delimitação do espaço de observação; composição do corpus empírico e, posteriormente, discursivo; operacionalização da rede conceitual; e análise dos recortes selecionados." (FARIA, 2016, p. 87). Um de 
nossos objetivos, neste estudo, é entender "o processo e as condições de produção de um discurso [...];” (MINAYO, 2008, p. 324-325).

Em suma, nosso esforço analítico é o de

[...] percorremos o olhar de analistas sobre o texto em busca de sua historicidade (o externo que é interno), investigando o ponto de encontro entre o ideológico e o linguístico. Um ponto de encontro que não é transparente, pois, do contrário, efetuaríamos um trabalho de descrição e não de análise (MITTMANN, 2007, p. 1).

Preocupamo-nos com a historicidade presente no discurso por meio da análise dos elementos vinculados ao ideológico, mas também ao linguístico; por reconhecermos essa não transparência da linguagem, os estudos de Ginzburg (1989) nos ajudam nesse processo de análise do discurso, uma vez que "se a realidade é opaca, existem zonas privilegiadas - sinais, indícios - que permitem decifrá-las" (GINZBURG, 1989).

Os textos dos sujeitos-alunos adquirem, aqui, um caráter primordial, visto que

[...] quando se trata de uma ciência como a análise de discurso em que a análise precede, em sua constituição, a própria teoria. Ou seja, é porque o analista tem um objeto a ser analisado que a teoria vai se impondo. Não há uma teoria já pronta que sirva de instrumento para a análise (ORLANDI apud MALDIDIER, 2003, p. 10).

Orlandi (2003) entende que a análise pode preceder a composição teórica de uma pesquisa, pois é a partir dela que a teoria vai construindo-se e moldando-se. $\mathrm{O}$ analista, a partir do seu olhar, faz escolhas teóricas que culminarão na interpretação, compreensão e significação dos dados.

Portanto, reconhecemos que as condições de produção interferem diretamente nos dados obtidos na pesquisa: "[...] em cada discurso, as condições de produção dadas são distintas, pois o que se diz, o que se enuncia, o que se promete, tem ou não determinado sentido, dependendo do lugar ou posição social de onde foi produzido" (PACÍFICO, 2002, p. 20). 


\subsection{Corpus}

Apresentamos as instituições escolares nas quais os textos foram produzidos com o intuito de entender o que se enuncia, para quem e qual posição discursiva o sujeito-aluno ocupa para sustentar o seu dizer. Seguimos a perspectiva de Minayo (2010, p. 75):

durante todas as etapas da pesquisa, tudo merece ser entendido como fenômeno social e historicamente condicionado: o objeto investigado, as pessoas concretas implicadas na atividade, o pesquisador e seu sistema de representações teórico-ideológicas, as técnicas de pesquisa e todo o conjunto de relações interpessoais e de comunicação simbólica.

As colocações da autora coadunam com a nossa concepção teórica, uma vez que entendemos que uma pesquisa deve ser concebida de acordo com esses critérios mencionados, para que entendamos o corpus como um fenômeno social que mantém laços com o contexto histórico. Ademais, o espaço de realização do estudo é uma variável imprescindível para o tratamento dos dados e para uma delimitação clara de quais e quantos sujeitos estarão envolvidos nesse processo, de modo a possibilitar uma sólida composição da dissertação, pois sabemos que há alguns critérios que devem ser levados em consideração na pesquisa qualitativa, dentre eles: "definir claramente o grupo social mais relevante, ou seja, sobre o qual recai a pergunta central da pesquisa" (MINAYO, 2011, p.197)".

De acordo com essas postulações, consideramos que o grupo social mais relevante para os objetivos de nosso estudo, no qual os sujeitos serão capazes de responder nossas indagações e hipóteses teóricas, é os estudantes da rede pública estadual, devido ao fato de eles serem diretamente afetados pela política de cotas nas universidades públicas, caso optem por participar desses vestibulares.

Delimitado o grupo social, selecionamos uma escola localizada em Ribeirão Preto, que, doravante, será denominada "Escola A", e outra instituição de ensino situada em Ituverava, "Escola B". A escolha das escolas justifica-se, primordialmente, pela viabilidade de realização da pesquisa. Por exemplo, visitamos uma escola localizada na zona norte de Ribeirão Preto, porém, a coordenadora pedagógica dessa instituição disse que os estudantes talvez não tivessem familiaridade com o texto dissertativo- 
argumentativo e que eles precisariam de "aulas complementares" antes participarem da pesquisa; tal fato, então, não seria condizente com nossos objetivos. Descartamos essa escola e buscamos escolas nas quais teríamos a posição de observador, ou seja, apenas assistirmos às aulas (todavia, não houve a possibilidade de sermos exclusivamente observadores); adotamos esse critério visto que "O pesquisador deve, então, constituir um corpus, no sentido de um conjunto de textos construídos em função de um parâmetro que lhe confere uma unidade e permite submetê-los a uma mesma investigação" (AMOSSY, 2011, p. 140).

Além da escola mencionada, fomos a outra instituição situada no centro de Ribeirão Preto. A coordenadora pedagógica não se interessou em ouvir sobre nossos estudos e apenas solicitou que deixássemos um papel na escola para que ela pudesse ler. Essa postura da instituição, de não se mostrar interessada em dialogar, também nos impediu de realizarmos a pesquisa nessa escola.

Outro fato preponderante na escolha das escolas foi a greve da rede estadual de ensino em 2015 (uma das mais intensas dos últimos anos). A greve ocorreu no período da coleta de dados, de modo que seria inviável a nossa presença nessas instituições em um período sem alunos. No entanto, mesmo com os obstáculos mencionados acima, conseguimos realizar as práticas em duas escolas estaduais, no interior de São Paulo.

Detemo-nos em explicitar essas peculiaridades e escolhas, pois acreditamos que, para nós, analistas do discurso

As condições de produção incluem, pois os sujeitos e a situação. A situação, por sua vez, pode ser pensada em seu sentido estrito e em sentido lato. Em sentido estrito ela compreende as circunstâncias da enunciação, o aqui e o agora do dizer, o contexto imediato. No sentido lato, a situação compreende o contexto sócio-histórico, ideológico, mais amplo. Se separamos contexto imediato e contexto em sentido amplo é para fins de explicação, na prática não podemos dissociar um do outro, ou seja, em toda situação de linguagem, esses contextos funcionam conjuntamente (ORLANDI, 2006a, p. 15).

Compreender as circunstâncias da enunciação é indispensável para entendermos o contexto imediato do discurso, mas, também, para relacionarmos o "aqui e o agora" ao contexto sócio-histórico e ideológico. Essa relação se mostra indissociável: a instituição escolar e a sociedade. Para tal, devemos atentar-nos a "quem fala a quem, em que relação de lugares, qual é o estatuto de cada um dos participantes, quais são as 
circunstâncias exatas da troca, quais são o momento e o lugar em que ela ocorre" (AMOSSY, 2011, p. 133). De acordo com essa perspectiva, apontamos mais elementos relevantes para entender essas relações citadas por Amossy (2011) por meio da apresentação de cada escola, traços dos sujeitos-alunos e dos encontros que tivemos com esses discentes.

\section{Escola A}

A Escola A possui quatro turmas do terceiro ano do Ensino Médio no período da manhã. No entanto, a coordenação da instituição, juntamente com uma docente, orientou que realizássemos a pesquisa com duas turmas. De acordo com as profissionais, os alunos pertencentes às duas salas estariam, hipoteticamente, mais dispostos a participar.

Doravante, denominaremos as turmas como 1 e 2: cada uma possui aproximadamente 40 discentes matriculados, com idades entre 16 e 18 anos. A instituição está próxima à região central de Ribeirão Preto, mas recebe alunos oriundos de diversos bairros; alguns deles estudam na escola há anos, pois, além do Ensino Médio, há o Ensino Fundamental II. Há, também, outros discentes que são ex-alunos de escolas particulares.

Constatamos que pesquisar em escolas é algo complexo (para não dizer árduo), visto que essas instituições possuem um calendário próprio e atividades paralelas, previamente, estabelecidas. Apesar disso, houve um esforço para nos ajustarmos aos cronogramas institucionais, foi preciso realizar diversas visitas à Escola A para conseguirmos alcançar os objetivos do estudo. Desde já, ressaltamos que os dados que serão apresentados reclamam sentidos e interpretação.

Na primeira visita, em maio, ocorreu a apresentação do projeto de pesquisa para a coordenadora pedagógica, que solicitou mais informações acadêmicas e os documentos da Universidade de São Paulo (USP). A profissional nos informou sobre disponibilidade da escola, ou seja, a princípio disponibilizou apenas duas aulas com cada turma. Em conformidade com essa disponibilidade, solicitamos à Escola B o mesmo número de encontros com os discentes (embora essa instituição tenha se mostrado receptiva para outros momentos de interlocução) para que, pelo menos o período de coleta de dados constituísse, mesmo que, ilusoriamente, condições de produção semelhantes. 
Posteriormente, voltamos à Escola $\mathrm{A}$, mas a coordenadora não estava na instituição. No terceiro dia, ocorreu a aprovação oficial da coordenação e a orientação em relação às datas disponíveis para nossas visitas.

Retornamos no mês de junho, no dia indicado. Chegamos à Escola $\mathrm{A}$ às $7 \mathrm{~h}$ da manhã, e, apesar de a data ter sido escolhida, antecipadamente, tivemos que aguardar, pois todos os alunos do terceiro ano estavam realizando uma avaliação estadual. Às 10h30min fomos até a sala de aula da turma 1: os alunos estavam preparando um café da manhã, divertindo-se, cantando e tocando violão. Nesse momento, a coordenadora solicitou que eles interrompessem suas atividades para poderem conhecer a proposta da pesquisa. $\mathrm{O}$ professor presente também atendeu à solicitação.

Diante do ato da coordenadora, indagamos: interromper uma atividade favoreceu a receptividade dos discentes em relação ao nosso projeto? Há, nesse caso, uma relação hierárquica presente, sendo que tanto o professor como os alunos tiveram que acatar a decisão da coordenação. A nosso ver, essa circunstância afetou a adesão dos alunos à pesquisa. Nosso propósito era propiciar um momento no qual o sujeito-aluno pudesse disputar os sentidos e argumentar sobre uma questão social, visto que não queríamos que o estudo fosse tido como mais uma imposição de atividades escolares, mas, como uma situação de diálogo com os estudantes.

Visitamos a Escola A para dar sequência à pesquisa em outra manhã, mas os alunos da turma 1 e da turma 2 (que ainda não havíamos conhecido) estavam em "aula vaga" devido à falta de professores e, dessa forma, não pudemos realizar as atividades. A possível explicação para a não realização de nossas atividades é a interpretação dada pelos alunos interpretem sobre o momento vago como um período de recreação, socialização e integração com os colegas.

Em outro dia, tivemos a oportunidade de conhecer a turma 2 e apresentamos a proposta da pesquisa, do mesmo modo como havíamos realizado com a turma 1 , isso será relatado, posteriormente. Na semana seguinte, os alunos da turma 2 escreveram os textos e, no dia subsequente, os discentes da turma 1 também o fizeram. Em outras palavras, o primeiro encontro com a turmas 1 e 2 foi destinado à apresentação da pesquisa e à discussão sobre a temática proposta. $\mathrm{O}$ segundo momento foi destinado, exclusivamente, à escrita: após uma breve retomada temática com base nos pontos principais discutidos, apresentamos aos alunos a proposta de redação e solicitamos que elaborassem o texto em sala de aula sem a consulta de outras informações que não estivessem contidas na coletânea. 
Após as férias, retornamos à escola para agendar um novo encontro com os estudantes para sabermos quais foram suas impressões sobre a pesquisa e para dar prosseguimento aos diálogos, atendendo, também, à solicitação da coordenadora sobre esse novo encontro. Descobrimos que havia outro coordenador pedagógico responsável pela escola (a coordenadora anterior tinha se aposentado), e, além de conversamos com ele, conhecemos também um membro da Diretoria de Ensino Regional, o qual nos forneceu materiais de temática racial utilizados em reuniões pedagógicas para a formação dos professores sobre a cultura afro-brasileira.

Apesar de o papel que um professor desempenha em uma escola é extremamente relevante na educação dos alunos, nessa escola não obtivemos contato com a professora de Língua Portuguesa, portanto, não conseguimos dialogar com o sujeito-professor. Em suma, fomos à Escola A em dez momentos distintos.

De modo geral, os diálogos com os alunos foram proveitosos e eles disseram ter conhecimento sobre vestibulares, textos argumentativos e cotas raciais em universidades públicas brasileiras. Nesse sentido, muitos se interessaram em ouvir nossa proposta de atividades e de discussão, sendo bastante receptivos.

No segundo encontro, notamos uma dificuldade dos discentes para iniciar a escrita, muitos não quiseram participar da pesquisa, apesar de terem argumentado oralmente sobre o tema, porque se disseram "sem inspiração" e "sem ideia". Interpretamos tais fatos à luz de Pacífico (2002):

\begin{abstract}
A insegurança é mais marcante quando o aluno tem que produzir o texto escrito, pois muitas vezes o aluno expõe, oralmente, seu conhecimento sobre determinado objeto, mas quando precisa escrever sobre o mesmo, diz que não sabe, que não consegue passar para o papel aquilo que acabou de falar (PACÍFICO, 2002, p. 87).
\end{abstract}

A partir da postulação de Pacífico (2002), consideramos, também, que sermos pesquisadores da USP interferiu na decisão de alguns alunos em não escrever o texto, talvez por não sermos seus professores e porque não tivemos tantas oportunidades de interlocução direta com as turmas; ou, ainda, por eles terem receio do texto "sair dos muros da escola" e ter leitores e avaliações desconhecidos.

Apesar de no início do capítulo 3 termos apresentado esses conceitos como relativamente destoantes, a pesquisa quantitativa e a qualitativa não precisam ser 
totalmente antagônicas, pois há contextos nos quais atributos de um método podem ser relevantes para a compreensão de outro, ou seja, eles podem ser complementares:

A pesquisa qualitativa responde as questões muito particulares, que não podem ser quantificadas. Esta trabalha com significados, motivos, superações, inspirações e crenças. Aprofunda-se no significado das ações e das relações humanas, onde dados qualitativos e quantitativos (se houver) se complementam (EL@DIS, 2012, p. 72).

Sendo assim, ressaltamos que há outros dados relevantes para a significação metodológica: no momento da apresentação da pesquisa, havia 33 alunos em sala de aula da turma 1, e, no momento da coleta de dados, 30 discentes. Entretanto, apenas 15 quiseram escrever os textos; a outra parte da sala preferiu terminar um trabalho de História que "valia nota", mesmo a professora tendo autorizado a interrupção dessa tarefa para a participação na nossa pesquisa. O panorama descrito inquieta-nos devido aos significados que podem ser atribuídos ao realizar uma atividade que vale nota em detrimento da escrita de um texto dissertativo-argumentativo: os alunos têm disposição para realizar atividades que não serão avaliadas de um modo cartesiano e que não "valerão nota"? A escola, em seu sentido amplo, tem apresentado atividades cujo principal objetivo seja a aprendizagem do aluno por outros meios que não sejam as provas institucionais? Essas perguntas necessitam de mais estudos para serem respondidas. Por hora, constatamos que "Escrever na adolescência é uma atividade que pode exercer fascínio, revelando os desejos mais íntimos do sujeito, ou construir obrigação, preenchimento de linhas para alcançar uma nota" (GRIGOLETTO; AGUSTINI, 2009, p. 369), e se por um lado essa obrigação mostra-se como uma constante nas práticas escolares cotidianas, por outro, acreditamos que é possível motivar o fascínio do sujeito aluno para as práticas da escrita dentro e fora da instituição escolar.

Em relação à turma 2, no momento da apresentação da pesquisa, havia 29 alunos em sala de aula, e no segundo encontro, 24. Porém, apenas 14 deles quiseram escrever os textos. Salientamos que os discentes estavam em "aula vaga" e foram retirados desse momento (após alguns deles contestarem) para poderem participar da nossa pesquisa; os estudantes que não quiseram escrever ficaram em sala de aula sem outra atividade pedagógica. Talvez retirá-los do período de "recreação" não tenha favorecido a participação dos discentes. Sendo assim, há dúvidas se os estudantes que optaram por 
não escrever realmente não têm acesso ao arquivo ou se eles preferiram utilizar o silêncio (ORLANDI, 1997) como uma manifestação de resistência à atividade proposta. Também precisamos cogitar a hipótese de esses alunos não reconhecerem a importância que um texto pode possuir em uma sociedade letrada, ou, também, de terem medo da avaliação e do julgamento alheio.

Em síntese, tivemos, primeiramente, dois encontros: um no qual houve a leitura da coletânea (Anexos C, D e E) sobre a temática e a discussão em sala de aula, e outro, em que, com base na proposta de redação (Anexo F) os alunos escreveram. No terceiro momento, os alunos não apresentaram dúvidas em relação à pesquisa; todos quiseram manter sua participação (de acordo com o Termo de Livre Consentimento, eles poderiam desistir da pesquisa a qualquer momento), e dialogamos mais sobre o texto dissertativo-argumentativo. Logo, a Escola A propiciou um corpus de 28 textos em prosa, dissertativo-argumentativos.

\section{Escola B}

Apresentamos, também, a Escola B e as condições de produção encontradas para a constituição do corpus.

Essa instituição técnica de ensino está localizada na região central da cidade de Ituverava e possui duas turmas no terceiro ano do Ensino Médio. Uma delas tem aulas, exclusivamente, no período da manhã, denominada como "terceiro regular", e a outra é o "ensino integrado", ou seja, há aulas, majoritariamente, no período da manhã e outras à tarde, de modo que o ensino visa a também à formação técnica. A faixa etária dos discentes é entre 16 e 18 anos, e, dentre eles, há alguns que, além de estudar, trabalham e outros que fazem estágios em empresas sob a supervisão da escola.

Antes de conhecermos a instituição, enviamos o projeto de pesquisa para o diretor ler e avaliar, além de agendarmos uma data para um diálogo. Em seguida, apresentamos, pessoalmente, o projeto.

O contato presencial com a Escola B resume-se a três encontros. No mês de maio, houve a apresentação da proposta de pesquisa para o diretor e para a professora de Língua Portuguesa. Dessa forma, tivemos a oportunidade de estabelecer um contato com a docente, visto que, após a autorização, o diretor deu liberdade para a professora agendar as atividades diretamente conosco. Salientamos que houve boa recepção da Escola B Acreditamos que por eles terem desenvolvido projetos sobre a questão racial 
No mês de junho, conhecemos as turmas 1 e 2 . As visitas foram agendas para as duas turmas em uma mesma manhã e o coordenador pedagógico da instituição também quis participar das discussões, uma vez que ele havia estudado sobre a temática racial em um curso de pós-graduação. Os dois grupos estavam aguardando ansiosamente a nossa visita, pois a professora já havia mencionado que abordaríamos essa temática em nossos encontros.

Fizemos as leituras dos termos de consentimento, apresentamos a coletânea (Anexos C, D e E) e motivamos a discussão sobre o tema proposto. A instituição interessou-se pelo projeto e utilizou a nossa proposta de redação em uma de suas provas bimestrais, o simulado, que eles fazem, bimestralmente. Os alunos sentiram-se familiarizados com a temática no momento da escrita, pois já havíamos lido a coletânea e discutido a coletânea, anteriormente. A professora, gentilmente, digitalizou as redações dos alunos e enviou-nos por e-mail, permanecendo a instituição com os originais, visto que aquela produção textual tornou-se uma atividade avaliativa interna.

O terceiro regular possui 40 alunos matriculados e, desse total, 39 estavam presentes no dia da apresentação da proposta da pesquisa. O terceiro integrado possui 37 discentes matriculados, e 33 participaram do primeiro encontro. No segundo semestre, voltamos à escola para a discussão sobre a pesquisa realizada e para conversarmos com os alunos, após a leitura de seus textos e o início das análises. Pudemos conhecê-los um pouco mais por meio da escrita. De acordo com Orlandi, "a escrita, ou seja, a redação é o meio de se ter acesso à leitura do aluno" (ORLANDI, 1993, p. 91). Sendo assim, o segundo (e último) encontro foi posterior à escrita das redações realizadas durante o simulado. Naquele momento, os alunos apresentaram suas percepções em relação à pesquisa e sobre como foi participar dela.

Entretanto, não tivemos "acesso à leitura" de muitos deles, pois alguns estudantes disseram que não participaram da pesquisa (todos escreveram os textos, mas nem todos trouxeram as autorizações assinadas pelos responsáveis): alguns não consideraram seu texto bom o suficiente; outros disseram que não obtiveram uma boa nota atribuída pela professora; outros, por sua vez, alegaram que a argumentação não estava suficientemente boa, ou, ainda, que tinham fugido do tema, parcialmente, pois abordaram a questão de cotas em relação aos alunos oriundos do ensino público, e não, especificamente, em relação aos afrodescendentes. Enfim, constatamos que 77 alunos escreveram os textos, mas apenas 13 estudantes do "ensino integrado" e 4 do "ensino 
regular" participaram integralmente da pesquisa. Em suma, a Escola B forneceu-nos 17 textos dissertativo-argumentativos.

\section{Os diálogos com os sujeitos-alunos}

Após caracterizarmos as escolas participantes da pesquisa e explicitarmos algumas interpretações sobre essas instituições, apresentamos, agora, o método de escolha dos textos utilizados na coletânea e algumas peculiaridades dessas opções a partir do nosso embasamento teórico. Cabe ressaltar que cada encontro em sala de aula teve, aproximadamente, 45 minutos de duração.

O primeiro encontro foi destinado à nossa apresentação: explicamos a constituição da pesquisa de mestrado e demonstramos como ela pode ser importante para a sociedade. Entregamos o termo de consentimento direcionado aos alunos e outro que foi direcionado aos pais; lemos os documentos, esclarecemos as dúvidas e salientamos que participar da pesquisa por meio da elaboração textual seria totalmente opcional, e que eles poderiam desistir disso a qualquer momento.

$\mathrm{Na}$ sala de aula, distribuímos nosso material de apoio (em anexo), uma folha para cada estudante e, em seguida, conversamos sobre temáticas relevantes para os intuitos do estudo: universidades públicas brasileiras, universidades particulares presentes nas cidades deles e, depois, discutimos sobre os métodos utilizados para o ingresso nessas instituições, os vestibulares, como, por exemplo, o ENEM. Conceituamos, também, as políticas afirmativas:

As políticas afirmativas visam ao: “[...] incremento da contratação e promoção de membros de grupos discriminados no emprego e na educação por via de metas, cotas, bônus ou fundos de estímulo; bolsas de estudo; empréstimos e preferência em contratos públicos; determinação de metas ou cotas mínimas de participação na mídia, na política e outros âmbitos; reparações financeiras; distribuição de terras e habitação; medidas de proteção a estilos de vida ameaçados; e políticas de valorização identitária" (GEMAA, 2011, p. 4).

O conceito do Grupo de Estudos Multidisciplinares de Ação Afirmativa (GEMAA) não abrange a totalidade do tema, mas escolhemos essa citação por ser 
representativa e capaz de motivar as primeiras discussões sobre as cotas com os sujeitos-alunos. Em seguida, solicitamos que os alunos anotassem seus posicionamentos sobre as cotas raciais a partir da seguinte indagação:

O que você pensa sobre as cotas direcionadas para afrodescendentes em universidades públicas brasileiras para que eles estudem nesses locais?

A pergunta, também, foi realizada a fim de motivar a reflexão dos sujeitosalunos para que eles pensassem em alguns argumentos sobre a temática.

Sabemos que os sujeitos valem-se da argumentação não apenas para explicitar um conceito lógico e formal, pois há a "tentativa de fazer aderir não somente a uma tese, mas também a modos de pensar, de ver e de sentir" (AMOSSY, 2011, p. 130). Os diálogos buscaram proporcionar: um espaço fecundo para a argumentação.

Reiteramos que não tínhamos o objetivo de fazer o sujeito aderir a uma tese ou outra, ou seja, não nos posicionamos a favor nem tampouco contra as cotas raciais, pois o intuito é problematizar a questão a fim de que haja a compreensão de como e se o sujeito-aluno posiciona-se sobre o tema.

Para o sujeito argumentar, é necessário que ele tenha acesso ao arquivo para defender seus argumentos. Em outras palavras, reconhecemos que "É preciso ainda considerar aqui a questão da divergência de pontos de vista, que está na base da argumentação" (AMOSSY, 2011, p. 130). Lemos dois textos sobre a temática das cotas raciais, um deles contendo argumentos favoráveis, e o outro, argumentos desfavoráveis sobre cotas para afrodescendentes.

A composição da coletânea foi uma etapa interessante de nosso estudo, pois refletimos sobre quais seriam os textos mais indicados para o propósito em questão, já que não conhecíamos os discentes e teríamos um tempo limitado no primeiro encontro (e nos outros também) para desenvolver as atividades. Uma das opções seria a presença do texto jornalístico, porém, reconhecemos que "a imprensa de modo geral provoca nos leitores ou ouvintes efeitos de verdade, como se não houvesse recortes, escolhas, interesses em jogo, ilusão que sustenta o mito da informatividade para poder dizer/relatar o que interessa a alguns" (CORACINI, 2003, p. 204).

Além disso, sabemos que esses textos podem ser tendenciosos. Os estudos de Lemes (2013) apontam que há livros didáticos que, frequentemente, expõem apenas o texto jornalístico como exemplo ou como modelo de texto dissertativo-argumentativo, o 
que não entendemos ser o ideal, visto que o livro, por exemplo, poderia apresentar textos escritos por outros alunos a fim de possibilitar a compreensão da dissertação.

Posteriormente, optamos pela utilização de um texto de divulgação científica, mesmo sabendo que, conforme os estudos de Marangoni (2013) indicam, essa tipologia textual muitas vezes mascara a produção do conhecimento por meio da voz do jornalista, o qual, muitas vezes, apropria-se de conceitos de discurso científico mediante a apresentação de dados fragmentados ou inconclusivos, apresentando-os como se representassem a ciência. Trata-se de um fato que explicita o poder concedido à imprensa de retratar o mundo, visto que ela "está autorizada a falar sobre ele, a retratálo, torná-lo compreensível” (CORACINI, 2003, p. 204).

Escolhemos os textos "A reserva de vagas dá oportunidade aos menos favorecidos frequentarem instituições de qualidade", de Letícia Januário e "O grande erro das cotas", de Julia Carvalho, para comporem a nossa coletânea não por valorizarmos o texto jornalístico em detrimento de outros gêneros textuais, mas por serem bons mediadores na discussão diante do tempo que tivemos disponível para tal. Ademais, esse gênero faz parte das coletâneas de grande parte dos vestibulares. Em relação à proposta de redação, salientamos que a proposta $\mathrm{B}$ foi parcialmente alterada pela docente da Escola B, de acordo com seus objetivos didático-pedagógicos.

A partir dos três encontros com as duas turmas da Escola A e os dois encontros com as duas classes da Escola B conseguimos os elementos necessários para a constituição do corpus da pesquisa, que possui ao todo quarenta e cinco textos dissertativo-argumentativos dos sujeitos-alunos. Apesar dessa constatação, reconhecemos que "o corpus não está dado, mas é construído pelo gesto do analista de ler, relacionar, recortar e, novamente, relacionar (MITTMANN, 2007, p. 1), ou seja, mostraremos no próximo capítulo nossos gestos de leitura com base na teoria discursiva e para tal não visamos a apresentar "[...] modelos prontos, definidos anteriormente a seus objetos, que podem nos levar a uma análise conteudística, onde o que temos a dizer serve apenas para comprovar uma conclusão pré-estabelecida" (LAGAZZI, 1988, p. 51), ao contrário, por meio dos recortes queremos compreender o discurso do sujeitoaluno dentro do Aparelho Ideológico Escolar para entendermos a FD desses sujeitos e analisar os sentidos presentes nesses textos. 


\section{ANÁLISES}

Mais uma vez contempla a palavra escrita na estrada.

(COUTO, 2015, p. 36)

Neste capítulo, apresentamos as análises dos recortes dos discursos dos textos dos sujeitos-alunos que constituem o corpus desta pesquisa.

A língua aparece como condição de possiblidade do discurso, pois é "um lugar teórico onde se encontram intrincadas, literalmente, todas as questões sobre a língua, a história e o sujeito" (MALDIDIER, 2003, p. 15). Essa consideração se mostra pertinente para podermos compreender como se dá o processo de análise, uma vez que

A análise é um processo que começa pelo próprio estabelecimento do corpus e que se organiza face à natureza do material e à pesquisa (ponto de vista) que o organiza. Daí a necessidade de que a teoria intervenha a todo momento para 'reger' a relação do analista com seu objeto, com os sentidos, com ele mesmo, com a interpretação (ORLANDI, 2007, p. 64).

Orlandi (2007) demonstra o quão importante é o diálogo entre a teoria e o processo de análise do discurso, visto que a teoria tem a função de orientar o analista em suas práticas a fim de estabelecer uma relação íntima com o corpus, com os sentidos que ecoam dele e com a interpretação desses elementos. Há alguns métodos de análise textual que são formalistas e estruturalistas, pois se ocupam essencialmente com os aspectos gramaticais em detrimento do conteúdo e do sentido. De acordo com Giroux (1983, p. 66), há analises que

Ao invés de tratar a escrita como um processo que é tanto o meio como o produto da experiência de cada um no mundo, esta posição despe a escrita de suas dimensões críticas e normativas e a reduz à aprendizagem de habilidades que, ao nível mais restrito, enfatiza o domínio de regras gramaticais. Em um nível mais 'sofisticado'- mas não menos positivista- a ênfase é posta no domínio formalista de estruturas sintáticas complexas, frequentemente sem considerar o seu conteúdo.

Giroux (1983) critica linhas teórico-analíticas que possuem uma perspectiva positivista, pois se preocupam apenas com aspectos normativos do texto por 
privilegiarem o domínio de regras gramaticais. Para a $\mathrm{AD}$, linguagem é constitutiva do sujeito e o discurso e os sentidos presentes no texto são mais consideráveis que as estruturais textuais, visto que é por meio da linguagem que o sujeito pode compreender o mundo e o interpretar. Assim, não nos dedicamos à correção dos textos, nem tampouco queremos julgar a escrita dos sujeitos-alunos (ou o trabalho das Escolas A e B). Definitivamente, esse não é o nosso propósito, pois, como já pontuamos, objetivamos analisar o discurso presente na escrita dos sujeitos-alunos sem nenhuma interferência feita por nós.

Uma das práticas relevantes que o sujeito pode realizar é a escrita; é por meio dela que ele se singulariza e consegue expor sua visão de mundo, bem como estar nele. Assim, ela pode ser também pensada como uma prática social.

Griogoletto e Agustini (2009, p. 371) entendem a escrita como um modo de singularização que possui marcas de subjetividade: “O sujeito, ao escrever, se singulariza, se expõe no texto, deixando marcas próprias, mas, ao mesmo tempo, é determinado pelo outro, seja esse o sujeito a quem se dirige, ou a instituição a que está vinculado".

Coracini (2007, p. 141) assevera que por meio da escrita é possível notar "diferenças no falar que apontam, para diferenças sociais (de ser, de se comportar)", principalmente, quando essas diferenças no falar, e, consequentemente, no escrever, apontam para caminhos opostos aos normativos. Levando isso em consideração, reafirmamos que os textos são apresentados tal como foram produzidos, mesmo quando apresentarem desvios em relação à chamada língua culta.

O texto dissertativo-argumentativo possui uma estrutura, com regras e normas que o sujeito-aluno é orientado a obedecer; todavia, defendemos que a $\mathrm{AD}$ "deve poder acolher as diferenças sem apelar para a noção de erro" (ORLANDI, 2011, p. 119). Concordamos com Orlandi (2011): a "noção de erro" não coaduna com a nossa perspectiva teórica.

Diante da constatação de que "a análise do discurso se preocupa com o processo de construção do discurso e não com o seu produto" (PACÍFICO, 2002, p. 63), não temos o intuito de analisar minuciosamente cada redação no que concerne à estrutura ou ao número de linhas escritas. Aqui, trabalhamos com o conceito de recorte, que entendemos como "uma unidade discursiva: fragmento correlacionado de linguagem - e - situação" (ORLANDI, 2011, p. 139). Optamos por transcrever os recortes das redações, uma vez que isso facilita a leitura e por meio deles analisamos as 
materialidades linguísticas, o que nos leva à compreensão do funcionamento discursivo dos textos, assim: "os recortes, aqui, não devem ser compreendidos tal qual uma estrutura linear, mas sim, como pedaços, 'nacos' do discurso, onde estarão materializados linguisticamente os indícios de um modo de funcionamento discursivo" (PACÍFICO, 2002, p. 62). Esses indícios estão correlacionados ao conceito de "paradigma indiciário" postulado por Ginzburg (2002) que apresenta uma:

[...] proposta de um método interpretativo centrado sobre os resíduos, sobre os dados marginais, considerados reveladores. Desse modo, pormenores normalmente considerados sem importância, ou até triviais, "baixos", forneciam a chave para aceder aos produtos mais elevados do espírito humano (GINZBURG, 2002, p. 149-150).

A AD apresenta a possibilidade de análises de diversos dispositivos, incluindo o texto escrito, já que esse pode apresentar pistas e indícios interpretativos que não são evidenciados diretamente.

Decidimos expor o recorte do texto do sujeito-aluno e, em seguida, entre parênteses, o título da dissertação ou, ainda, "(Sem título)", para aqueles que não apresentam título. Pacífico (2002), em sua tese de doutorado, analisou discursivamente textos de universitários do curso de Psicologia, de uma universidade particular do interior de São Paulo, constatou que alguns deles não apresentavam títulos, e, em suas análises, concluiu que:

Começa aí a quebra da unidade textual, considerando que o título faz parte da organização do texto, pois pode condensar aquilo que será expandido na construção textual, fornecendo ao leitor uma pista de leitura. O título é a primeira tentativa de controle da deriva; a marca inicial da autoria, que pode ou não se efetivar no texto (PACÍFICO, 2002, p. 94).

Concordando com Pacífico (2002), concebemos o título como um indício de autoria, visto que a ausência de título pode significar também uma quebra no poder de argumentação. Assim, essa compreensão mostra-se crucial, pois a argumentação e a autoria apresentam uma relação intrínseca.

A seguir, seguem algumas considerações sobre o que é esperado nos manuais didáticos e nos vestibulares dos sujeitos-alunos ao produzirem os textos dissertativo- 
argumentativos, bem como alguns recortes desses textos, a fim de observar se e como o discurso sobre o texto dissertativo-argumentativo afetou os sujeitos deste estudo.

Nosso estudo visa a interpretar os discursos em relação à sociedade, pois buscamos, também, realizar "um estudo que se propõe tanto realçar um funcionamento discursivo, quanto tratar, no corpus selecionado, de uma questão social.” (AMOSSY, 2011, p. 140), e a questão social escolhida, neste caso, é implementação e a permanência das cotas raciais em universidades públicas brasileiras. Selecionamos essa temática devido à sua relevância, e não conseguiríamos conceber uma investigação acadêmica que não se relacionasse diretamente com a sociedade.

O texto dissertativo-argumentativo foi a nossa escolha em razão de propiciar a divergência de pontos de vista e a disputa pelo objeto discursivo. Esse gênero é o mais solicitado em vestibulares. Logo, os vestibulandos têm a necessidade de conhecer as orientações para a elaboração da redação. Acerca desses parâmetros externos (com os quais não coadunamos), destacamos que a Revista Arquitetura da Redação UEPG (2013) alega que o aluno, que estudou durante doze anos no Ensino Fundamental e Médio, deve ser capaz de expor suas opiniões por meio do texto dissertativoargumentativo. Para a Universidade Estadual de Ponta Grossa, espera-se de seus futuros discentes:

Ler e escrever, amiúde, permitem internalizar de modo natural as regras que compõem a produção de um texto, gerando uma facilidade de apreensão e aplicação de critérios discursivos e gramaticais avaliados pela UEPG como:

$>$ demonstrar capacidade de compreensão e interpretação de texto (s) de expressão escrita, em uma proposta temática para produção de um texto de opinião dissertativo-argumentativo;

$>$ ser fiel ao que propõe o enunciado da questão;

$>$ mostrar desempenho linguístico de conformidade com a norma padrão da língua escrita, ou em consonância com a variedade linguística, de acordo com a proposta;

$>$ estruturar o texto;

$>$ organizar o texto com coesão e coerência;

$>$ construir bem os parágrafos, frases, orações; atentar para o vocabulário, a ortografia, a pontuação, a concordância, a regência etc. (UEPG, 2013, p. 10 ).

Trazer as expectativas das instituições universitárias é interessante para entendermos quais exigências são, tradicionalmente, cobradas do vestibulando ao 
escrever. Ademais, a revista possui diversas orientações acerca do que é considerado pela instituição como uma boa dissertação, bem como alguns textos corrigidos pela banca examinadora da universidade, dentre outras instruções direcionadas aos vestibulandos. Questionamos, também, o título da revista, visto que a palavra "arquitetura" pode evocar sentidos positivistas relacionados à construção de um texto como se fosse algo estritamente estrutural.

Além disso, um quesito, frequentemente solicitado ao candidato de vestibular, é a imparcialidade na dissertação, ou seja, o texto deve ser escrito de modo referencial (denotativo) e, predominantemente, em terceira pessoa. Esse fato pode ter um resultado: "o sujeito é mascarado pelo uso obrigatório da terceira pessoa no texto dissertativo, o que sugere uma subjetivação evanescente" (GRIGOLETTO; AGUSTINI, 2009, p. 378). Grigoletto e Agustini (2009) posicionam-se contra essa estabilização proposta pelos vestibulares e asseguram que a imparcialidade não existe e que todo e qualquer texto é atravessado pela subjetividade. Concordamos com as autoras visto que o sujeito ao escrever um texto dissertativo em terceira pessoa visa a postular um saber que é tido como científico, todavia, sabemos que o caráter histórico, ideológico e social não é passível de apagamento.

Correlacionado ao processo linguístico de apagamento do sujeito, o estudo de Tfouni (1995) reconhecem que há mecanismos que levam o texto a uma noção de generalização e universalidade: há um apagamento do "Eu", por meio de mecanismos linguístico-discursivos, e o uso de "Todo X" na função de sujeito do enunciado. Vejamos alguns recortes do nosso corpus os quais podemos aproximar da análise de Tfouni (1995):

\section{Recorte 1}

A política de cotas destinadas as pessoas negras, pardas ou indígenas é uma das alternativas que visa minimizar desigualdades existentes entre negros e brancos." (A importância da política de cotas).

\section{Recorte 2}

Foi aprovado pelo Congresso a Lei no. 12. 711, chamada Lei das Cotas. Na qual tem por objetivo minimizar a desigualdade racial e social no país". (Investindo no futuro). 


\section{Recorte 3}

As cotas raciais em universidade brasileiras é de extrema importância, nos dias de hoje $52 \%$ da população são negros e ainda assim há uma grande desigualdade racial entre brancos e negros" (As cotas raciais e a sua importância).

Nos recortes 1, 2 e 3, com base no uso da pessoa verbal, notamos que os sujeitos-alunos escreveram de modo relativamente imparcial, eles tentam, possivelmente, controlar elementos textuais que poderiam evocar a subjetividade: "E isso nos aponta para os padrões e regras institucionais determinando a escrita do aluno" (GRIGOLETTO; AGUSTINI, 2009, p. 377).

Grigoletto e Agustini (2009) criticam o modo como o texto dissertativoargumentativo, muitas vezes, é ensinado na escola, sobretudo frente à impossibilidade da constituição de um texto imparcial, pois o sujeito é constituído pela subjetividade e o texto pode ser mais ou menos subjetivo, mas nunca é imparcial. As autoras postulam, ainda, que a escola deve propor diferentes propostas nas quais o sujeito-aluno possa inscrever-se socialmente por meio da escrita.

Uma das vozes da instituição escolar é o livro didático e alguns deles também valorizam o uso da terceira pessoa. A título de exemplo, o recorte abaixo está no livro utilizado na Escola B (Português: linguagens 3, escrito por Cereja e Magalhães e publicado em 2013) e apresenta os textos “Acesso à informação é motivo para ir à escola?”, de Newton Campos e “A hora da geração digital”, de Don Tapscott. 
Figura 2 - Escrevendo com adequação

\section{ESCREVENDO COM ADEQUAÇÃO}

\section{A IMPESSOALIZAÇÃO DA LINGUAGEM}

Leia os textos a seguir e responda às questões propostas.

\section{TEXTO I}

\section{Acesso à informação é motivo para ir à escola?}

Hoje em dia não mais. A informação está na mão. Nas pontas dos dedos para ser mais preciso. [...]

Passei esta semana viajando pela América do Sul [...]. Segunda-feira, em Santa Cruz de la Sierra, dei duas conferências interativas similares, baseadas em minha atividade acadêmica. Os públicos eram bem distintos: alunos de uma escola secundária privada de alto nível (na faixa dos 17 anos) e adultos procurando cursos de pós-graduação no exterior (na faixa dos 30 anos).

Para minha surpresa, mesmo sem ter nenhuma experiência profissional no assunto, os alunos do colégio estavam mais bem informados sobre os assuntos discutidos do que os adultos, em geral profissionais destacados em suas profissões.

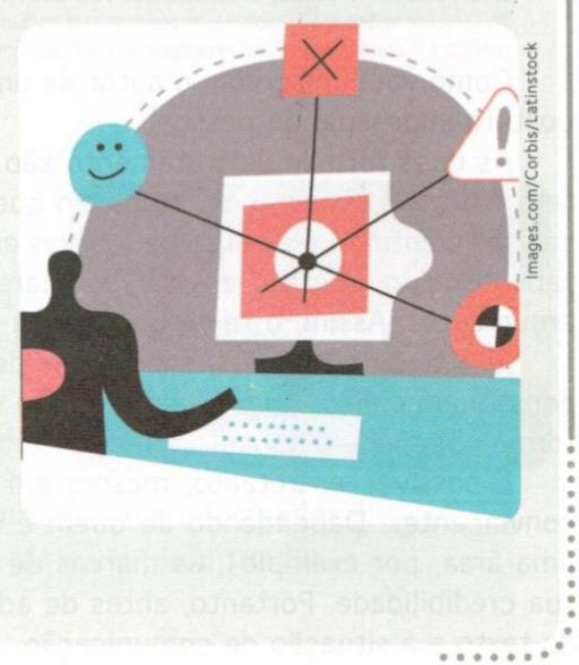

\section{TEXTO II}

\section{A hora da geração digital}

[...] 0 poder da internet para descentralizar o conhecimento acarretou um profundo deslocamento de poder dos produtores para os consumidores. Os jovens da Geração Internet têm mais acesso a informações sobre produtos e serviços e podem discernir o valor real com mais facilidade do que as gerações anteriores. [...] A influência também está sendo descentralizada à medida que a Geração Internet se manifesta a partir das trincheiras modernas, também conhecidas como blogs. Blogs e outras mídias geradas por consumidores estão alterando as fontes de poder e de autoridade em nossa sociedade. Algumas dessas fontes têm uma capacidade surpreendente de influência, afastando a balança de poder de fontes mais tradicionais e reconhecidas. [...]

(Don Tapscott. Trecho do livro A hora da geração digital. Disponivel em: http://catracalivre.folha.uol.com. br/2010/06/\%e2\%80\%9ca-hora-da-geracao-digital\%e2\%80\%9d-don-tapscott/. Acesso em: 22/6/2012.)

Fonte: CEREJA, W.; MAGALHÃES, T. Português: linguagens, 3. - 9. Ed- São Paulo: Saraiva, 2013, p. 259). 
Notamos que o primeiro texto apresenta marcas de subjetividade expressa pelos verbos "passei”, “dei” e pelo pronome possessivo "minha”. Já o segundo é considerado impessoal, porque tenta apresentar o desaparecimento do eu e dos índices de subjetividade (como se isso fosse possível). Ademais, esse trecho do livro "A hora da geração digital" é apresentado como um modelo para se escrever adequadamente em terceira pessoa e a seção do livro denominada "Escrevendo com adequação" pode indicar que escrever corretamente ocorre por meio da impessoalização da linguagem.

Nos recortes 1, 2 e 3 observamos que os sujeitos-alunos tentam escrever de modo impessoal, valorizado pelo livro didático, assim como nos manuais destinados a vestibulando, em detrimento de textos que apresentam marcas de subjetividade. Esses sujeitos-alunos apresentam em seus textos sentidos sobre a desigualdade racial existente no Brasil.

Apresentamos, neste momento, as análises discursivas do corpus que foram organizadas por seções as quais se constituíram por sentidos dominantes em dadas formações discursivas; Foucault (1995, p. 51) foi um grande estudioso sobre esse conceito e ele entende que: "[...] no caso em que entre os objetos, os tipos de enunciação, os conceitos, as escolhas temáticas, se poderia definir uma regularidade (uma ordem, correlações, posições de funcionamentos, transformações), dir-se-á, por convenção, que se trata de uma formação discursiva". Essas formações são destacadas, na subseção 4.1, devido a sua recorrência nos textos dos sujeitos-alunos. As seções são as seguintes:4.1)Todos, Eles e Nós: a inclusão/exclusão do sujeito na FD do ser ou não ser afrodescendente; 4.2) $\mathrm{O}$ discurso sobre (in) capacidade dos afrodescendentes; 4.3) Argumentos favoráveis às cotas; 4.4) Argumentos desfavoráveis às cotas.

\section{1 Todos, Eles e Nós: a inclusão/exclusão do sujeito na FD do ser ou não ser afrodescendente}

O surgimento do Estado Moderno trouxe consigo o efeito de igualdade entre os cidadãos, pois um dos objetivos da burguesia é simular um apagamento das diferenças por meio das leis e de uma perspectiva mais universalizante.

Nessa perspectiva- da interpenetração de classes e da absorção das diferenças- é que chegamos ao jogo de palavras existente 
em relação aos conceitos de 'liberdade' e 'igualdade': a burguesia sempre proclama o ideal da igualdade ao mesmo tempo em que organiza uma desigualdade real. (ORLANDI, 2011, p. 206).

De acordo com Orlandi (2011), a burguesia difunde o ideal de igualdade em uma sociedade desigual. Antes, na Idade Média, havia uma sociedade estratificada, em que a mobilidade social era rara. Com a consolidação da burguesia e o ideal de "Liberdade, Igualdade e Fraternidade", difundido, especialmente, na Revolução Francesa (1789), tem-se, por meio do apagamento das diferenças, a propagação de sentidos de que todos são iguais. No entanto, também reconhecemos que a sociedade está organizada de modo desigual. Um dos mecanismos da burguesia é o Direito, que apresenta a função de regular as normas de conduta, o que é certo e o que é errado e, nesse sentido, seria considerado, por muitos, como algo inquestionável.

Em nosso corpus, há muitos textos que se posicionam contra as cotas raciais e grande parte deles valem-se do argumento de autoridade de que "todos são iguais". Teoricamente, esse argumento é inquestionável, ou seja, possivelmente, faz-se referência à Constituição da República Federativa do Brasil de 1988 (BRASIL, 2010), cujo quinto artigo do primeiro capítulo do Título II afirma que "todos são iguais perante a lei, sem distinção de qualquer natureza, garantindo-se aos brasileiros e aos estrangeiros residentes no País a inviolabilidade do direito à vida, à liberdade, à igualdade, à segurança e à propriedade". (BRASIL, 2010, Capítulo I, Artigo 5º ). As dissertações apresentam uma paráfrase dos sentidos de igualdade que circulam como evidentes, ou seja, isso culmina nos efeitos sociais de verdade e na "evidência" de sentidos de igualdade. De acordo com Althusser (1971) quando o sujeito exclama “[...] é evidente! É isso! Não há dúvida" (ALTHUSSER, 1971, p. 96) há uma evidência ideológica de sentidos, pois ele foi capturado por uma ideologia. Em nosso corpus interpretamos que há uma naturalização de sentidos de igualdade.

Nossos recortes apontam para sujeitos que se posicionam contrariamente às cotas raciais a partir da prerrogativa de que todos são iguais perante a lei. Porém, diferentemente do que destacamos anteriormente, que o sujeito tinha um apagamento do eu em seus textos diante dos imperativos do gênero textual em questão, nos próximos recortes, os sujeitos utilizam verbos em primeira pessoa e o pronome pessoal "nós". Há também a presença do pronome indefinido plural "todos" e do pronome em terceira 
pessoa "eles". As escolhas pronominais ou lexicais podem indiciar sentidos de inclusão e de exclusão do sujeito no discurso.

\section{Recorte 4}

[...] No Brasil as cotas raciais prevalece em todos os lugares, mas eu mesmo sou contra isso pois todos nós temos a mesma capacidade [...] $\underline{\text { Somos todos iguais por isso acho }}$ que não pode haver cotas. [...] Sou totalmente contra essa cota raciais na minha deve mudar essa lei. Isto é meu pensamento, somos todos cidadões (As cotas raciais no Brasil).

\section{Recorte 5}

Isso poderia mudar para todos serem iguais independentemente da cor, e com isso todos iriam correr atrás do seu objetivo, e não pensar que tem vagas para eles. Todos somos capazes de fazer tudo que queremos so basta correr atrás (Cotas? Para que).

\section{Recorte 6}

Contudo, todos os humanos são iguais, logo para conquistarem a vaga, o primordial é a meritocracia. Deve-se instigar e motivar o negro sobre sua capacidade, não menosprezaló, pois a cor do conhecimento é igual para todos (A cor do conhecimento).

Os recortes 4, 5 e 6 mostram como os sujeitos-alunos usam a primeira pessoa do singular e do plural em sua escrita, indiciando que os sujeitos inscrevem-se em seus textos. Mesmo submetidos às regras escolares sobre a objetividade exigida escrita da dissertação, eles não se filiam aos sentidos escolares e marcam seus posicionamentos, explicitamente, com o uso dos pronomes "eu" e "nós". Além disso, há uma paráfrase dos sentidos apresentados nas leis que postulam que todos são iguais. O sujeito-aluno do recorte 5, ao usar o pronome "eles", marca um distanciamento em relação aos afrodescendentes.

O sujeito que encontramos na perspectiva da $\mathrm{AD}$ é cindido e passível de falhas, lapsos e no próximo recorte, também, veremos o funcionamento dessa cisão materializado nas palavras "todos", "nós" e "eles". O sujeito-autor, muitas vezes, tenta controlar os sentidos para manter um texto coerente, mas deslizes podem ocorrer, visto que 
o sujeito (da linguagem), que busca em vão a completude, sua e da 'sua' língua, porque se percebe incompleto, falho assim como é falha e incompleta a língua- o que provoca angústia, frustração-, que se crê homogêneo (ou assim desejaria ser), mas se flagra na heterogeneidade-sujeito clivado, múltiplo, incapaz de controlar e de se controlar; que crê na língua unívoca, transparente e monossêmica, mas que, a todo momento, surpreende-se com a necessidade de precisar o sentido, de definir termos, de remediar os mal-entendidos; depara, não raro, com os atos, os lapsos, os deslizes de sentido e, neles, com o seu próprio deslize (CORACINI, 2007, p.145-146).

Coracini (2007) reconhece um sujeito incompleto, constituído pela subjetividade e pela heterogeneidade que nem sempre consegue controlar os sentidos e pode se deparar com o seu próprio deslize, em outras palavras, nem sempre o sujeito consegue controlar os sentidos presentes no seu texto, pois, no recorte 7, o sujeito-aluno apresenta a temática solicitada de modo referencial por meio dos verbos na terceira pessoa do plural ("mostram", "querem", "estudam", "batalham"), mas o "furo" ocorre com a formulação "mas precisamos dos 50\%", em que há um deslizamento de sentido e inserção do sujeito no discurso por meio do verbo em primeira pessoa "precisamos", retornando, posteriormente, o sentido para a terceira pessoa "Eles mostram que são capazes (...)". Além disso, há um sentido de busca pela igualdade, pois "todos tem capacidade e podem viver igual aos brancos".

\section{Recorte 7}

As cotas raciais são realmente necessárias, pois todos tem capacidade e podem viver igual aos brancos. A história dos negros são comoventes, e mostram que querem mudar de vida, e por isso, estudam e batalham para entrar em uma universidade, mas precisamos dos $50 \%$ para isso tornar ainda mais fácil. Eles mostram que são capazes e não ligam mais para o preconceito, tudo pode mudar. (Sem título).

Interpretamos que a formulação "mas precisamos dos 50\%" faz referência à Lei $\mathrm{n}^{\circ} 12.711$, que prevê que, até o ano de 2016, 50\% das vagas das instituições de ensino superior federais do Brasil devem ser reservadas para alunos oriundos de escolas públicas, de baixa renda, afrodescendentes e índios (dados presentes na coletânea). A escolha dessa formulação pode indiciar que o sujeito-aluno circula por duas formações discursivas: uma em que ele se assume como afrodescendente e outra marcada pelo 
distanciamento do sujeito afrodescendente por meio da negação desse pertencimento. Além disso, é possível que o sujeito acredite que o autor deve controlar a subjetividade e que o texto deve ser escrito em terceira pessoa, como foi apontado no início deste capítulo 4. No entanto, o sujeito, por ser cindido, não controla o deslizamento e, também, não produz um texto de acordo com as exigências de um vestibular, em que o controle da deriva e dos sentidos é fundamental, bem como o uso da norma culta padrão da Língua Portuguesa.

Mesmo o sujeito-aluno defendendo a necessidade da política de cotas, interpretamos que a palavra "comoventes", usada para adjetivar a história dos afrodescendentes, remete a uma memória discursiva sobre uma possível incapacidade ou inferioridade dos afrodescendentes e essa escolha se torna relevante porque exemplifica a relação do sujeito com o social e a contradição que é o constitui, pois "não é possível conceber transformação sem a existência simultânea da contradição, presente na língua, na historia e no discurso" (SCHONS; MITTMANN, 2009, p. 301).

De fato, a contradição está presente na língua, na história e no discurso, visto que mesmo quando o sujeito tenta "defender" os afrodescendentes, ainda, assim, há a necessidade de mostrar que "eles são capazes" e que "não ligam mais para o preconceito". Ademais, o verbo "batalham" reverbera a memória discursiva de que o afrodescendente luta para estar na universidade, por outro lado, "ainda mais fácil" mostra que ele consegue isso facilmente- o que mostra um sentido divergente do verbo "batalham".

Apesar da grande recorrência dos discursos que se posicionam contrariamente às cotas raciais se sustentarem por meio do sentido de igualdade, há um sujeito-aluno que se vale do sentido de igualdade presente no discurso jurídico para escrever algo, que, ousaríamos dizer, possui um tom de denúncia e tal recorte nos incita a reflexão.

\section{Recorte 8}

Devemos sim exigir melhorias no ensino público, mas levará algum tempo e até lá é preciso de algo mais imediato, afinal, não se pode falar em meritocracia em um país onde pregam que somos iguais, mas nos trata e nos dá oportunidades completamente desiguais e injustas. (Porque as cotas ainda são necessárias)

O recorte 8 mostra sentidos distintos se comparado ao recortes 4,5 e 6 . No recorte 8, o sujeito-aluno defende as melhorias do ensino público, alertando que esse 
feito poderia demorar, então, as cotas são uma solução imediata. Ele se posiciona contrariamente à meritocracia (citada no recorte 6) visto que todos os cidadãos são iguais mas as oportunidades e o tratamento social, possivelmente, direcionados aos afrodescendentes (grupo no qual fica implícito que ele se inclui pela utilização do "nos") são desiguais e injustos. O sujeito constrói o discurso com base no interdiscurso sobre ensino público, e, desse modo, apresenta argumentos de que o ensino básico público deve melhorar para, assim, denunciar as condições desiguais da sociedade capitalista e burguesa.

Com base nas análises apresentadas, nesta subseção, pudemos notar que há uma heterogeneidade nos discursos dos sujeitos e, consequentemente, das FDs às quais eles estão inseridos. Percebemos, no recorte 7, que o sujeito migra de uma FD para outra, ou seja, daquela em que ele se identifica como afrodescendente para outra em que não há a identificação. Muitos dos que se posicionam contra as cotas se valem de um discurso que prega a igualdade e a meritocracia e podem representar um discurso dominante que objetiva a manutenção da sociedade desigual. Interpretamos que o discurso sobre a igualdade pode ser tão excludente como outros discursos. Fato que se dá pelo efeito da ideologia que captura o sujeito e ele não se dá conta disso, uma vez que crê ser detentor de seu dizer. Ademais, os recortes 5, 6 e 7 além de sentidos de "igualdade" apresentam, também, sentidos vinculados à (in) capacidade dos afrodescendentes e outros recortes que também se valem desses sentidos serão analisados na próxima seção.

\subsection{O discurso sobre (in) capacidade dos afrodescendentes}

É importante ressaltarmos que "a ideologia é, em AD, o modo particular com que cada sujeito se relaciona com a linguagem" (SCHONS; MITTMANN, 2009, p. 301) e podemos perceber essa relação com a linguagem pelo modo que o sujeito se expressa por meio da escrita, que se mostra primordial para a materialização das ideologias, pois as "condições ideológicas da reprodução/transformação das relações de produção são determinantes no processo da escrita" (GRIGOLETTO; AGUSTINI, 2009, p. 371), assim, as condições ideológicas são essenciais no processo de produção de todos os textos.

Defendemos que a escrita é "tomada como prática social, espaço simbólico, lugar de interpretação, a partir da qual é possível resistir, produzir rupturas e 
(des)legitimar sentidos" (GRIGOLETTO; AGUSTINI, 2009, p. 369) e, ainda, a escrita pode ser utilizada para legitimar os sentidos dominantes em uma dada sociedade. Em nosso corpus notamos a recorrência e a legitimação de sentidos relacionados à (in)capacidade dos afrodescendentes e isso tem vínculos com os aspectos históricos e aos diversos anos que o Brasil viveu no regime escravocrata, visto que o sujeito "ao escrever, não só ele próprio se inscreve, mas também, inscreve seu texto numa dada discursividade, sócio-historicamente determinada" (GRIGOLETTO; AGUSTINI, 2009, p. 370).

Os recortes de nosso estudo indiciam por meio da escrita a relação do sujeito com o contexto sócio-histórico no qual ele está inserido e a interpretação que ele faz desses fatores externos. Reconhecemos que a FD está relacionada com a formação ideológica:

A formação discursiva é caracterizada pelas marcas estilísticas e tipológicas que se constituem na relação da linguagem com as condições de produção. De outro lado, podemos dizer que o que define a formação discursiva é sua relação com a formação ideológica. Assim, podemos perceber como se faz a relação das marcas formais com o ideológico. Podemos fazer o percurso nos dois sentidos: o que vai do ideológico para as marcas formais ou destas para aquele. Isso só é possível, entretanto, mantendo-se o conceito de Formação Discursiva como mediador. (ORLANDI, 2011, p. 132 grifo do autor).

Segundo Orlandi (2011), há um movimento ideológico para as marcas formais presentes no texto e o contrário também pode ocorrer e as FDs dos discursos são primordiais para compreendermos esse movimento.

O discurso está em constante diálogo com a exterioridade, de maneira que há elementos que determinam a prática na qual o sujeito é assujeitado e capturado por uma determinada FD. Notamos a presença de discursos que questionam ou explicitam a capacidade dos afrodescendentes, pois sabemos que, historicamente, no Brasil esse grupo exerceu o trabalho escravo (braçal) enquanto os portugueses e seus descendentes eram considerados aptos para o trabalho intelectual.

No corpus, observamos o movimento dos sujeitos-alunos em marcar o posicionamento de que os afrodescendentes são capazes e que possuem habilidade intelectual. A nosso ver, há uma tentativa de apagamento em relação à memoria 
discursiva de que os afrodescendentes são incapazes para as atividades intelectuais, visto que as cotas favorecem o ingresso em uma universidade e no século passado esse espaço era, predominantemente, destinado às classes dominantes e, consequentemente, os afrodescendentes, não ocupavam o espaço das instituições escolares, sequer, das universidades.

Encontramos sentidos parafrásticos em nosso corpus e é possível relacionarmos a memória discursiva à paráfrase, pois percebemos que "a memória não restitui frases escutadas no passado, mas julgamentos de verossimilhança sobre o que é reconstituído pelas operações de paráfrase" (SCHERER; TASCHETTO, 2005, p. 122). Sabemos que:

Ao dizer, o sujeito significa em condições determinadas, impelido, de um lado, pela língua e, de outro, pelo mundo, pela sua experiência, por fatos que reclamam sentidos, e também por sua memória discursiva, por um saber/poder/dever dizer, em que os fatos fazem sentido por se inscreverem em formações discursivas que representam no discurso as injunções ideológicas (ORLANDI, 2005, p. 53).

De acordo com Orlandi (2005), o sujeito significa impelido pela língua e pela sua experiência e os 2 elementos se relacionam com a memória discursiva à qual o sujeito tem acesso, aliados às FDs que representam, no discurso, as imposições ideológicas. A memória discursiva sobre quem é afrodescendente no Brasil, do que ele

pode e deve fazer na sociedade, movimenta muitos sentidos. É possível que os sujeitosalunos tenham a necessidade de mencionarem a (in)capacidade desse grupo porque esse sentido é possível na FD dominante no Brasil, sobre essa questão.

Os recortes 9, 10 e 11 representam sentidos vinculados à (in)capacidade dos afrodescendentes:

\section{Recorte 9}

Com isso não há necessidade de cotas, pois todos tem capacidade suficiente para ingressar no ensino superior.

Em critérios, é uma péssima colocação que eles fazem em relação a autodeclaração pois todos somos iguais e temos a mesma capacidade.

"Então de maneira consciente vamos tentar acabar com as cotas pois não são elas que vão por nós nas universidades, mas sim a capacidade suficiente de cada um".

(A desigualdade nas cotas) 


\section{Recorte 10}

[...] essas cotas muitas vezes fazem com que o racismo aumente ainda mais, pois a mesma capacidade que um branco teria de entrar em uma universidade, o negro também tem, mas com as cotas acabam atrapalhando, pois de certa forma acabam duvidando da inteligência dos negros, e não é dessa forma que "vamos ajudar" aos negros como dizem pois assim só estamos colaborando mais ainda com o preconceito. (“Ajudar” ou “colaborar"?).

\section{Recorte 11}

Os negros são pessoas capacitadas e batalhadoras diferente de muitos jovens brancos estudando em uma universidade paga sem se esforçar indo só para brincar. Negros, pobres e brancos devem estar no mesmo patamar. (Sem título).

No recorte 9, o sujeito-aluno assevera que não há necessidade de cota, visto que todos possuem capacidade para ingressarem no ensino superior. Interpretamos que esse recorte também está relacionado aos sentidos apresentados na seção anterior, pois apresenta sentidos de "igualdade" e há a presença de "todos", "eles" e "nós" e o uso desses pronomes indicia também um sentido de inclusão/exclusão no discurso. $\mathrm{O}$ sujeito-aluno, no recorte 9, escreveu quatro parágrafos de sua dissertação e apenas no último fez o emprego de aspas e concordamos que "O uso das aspas aponta para o interdiscurso [...]"( CORACINI, 2003, p. 216).

Observamos, também, que alguns textos apresentam sinais gráficos que são muito representativos, pois remetem ao interdiscurso visto que "É o conjunto de aspas, itálicos, entonação de modalização autonímica que apresentam marca que deve ser interpretada como referência a outro discurso" (AUTHIER-REVUZ, 1998, p. 143). O recorte 10, no título da dissertação (“Ajudar" ou "colaborar”?), também, faz referência a outro discurso. Há um discurso assistencialista em relação aos afrodescendentes, como se eles precisassem de ajuda ou de colaboração para conseguirem algo, o que pode indiciar uma tentativa de silenciamento da luta política desse grupo para alcançar condições melhores de vida. O recorte 11, assim como os dois recortes anteriores, valem-se do discurso de que os "negros são pessoas capacitadas". Entretanto, o sujeitoaluno migra para outra região de sentido ao diferenciar o "negro" do "branco" afirmando que na universidade particular o branco frequenta "sem se esforçar indo só 
para brincar". Ora, defendemos que não é a cor da pele que define o afrodescendente como capacitado nem o jovem branco como aquele que não valoriza os estudos, ou seja, a capacidade não pode ser determinada pela etnia do sujeito.

Os estudos de Pêcheux (1990) apontam que "todo enunciado é intrinsecamente suscetível de tornar-se outro, diferente de si mesmo, se deslocar discursivamente de seu sentido para derivar para um outro." (PÊCHEUX, 1990, p. 53) E o enunciado pode torna-se outro a partir da FD na qual o sujeito está filiado. Pêcheux (2012, p. 33) assevera que o sujeito pragmático tem por si mesmo uma imperiosa necessidade de homogeneidade lógica, entretanto o sujeito não é homogêneo, nem tampouco o seu discurso, como os recortes, 1 a 20, apontam.

No texto "Do acontecimento histórico ao acontecimento discursivo: o político na charge", Baronas e Aguiar (2009) para embasar suas análises das charges mostram os estudos de Pêcheux (2012) sobre On a gagné e mostram que esse enunciado "pode ser traduzido pela equação ' $\mathrm{X}$ diz $\mathrm{X}$ que pode significar a partir de diferentes formações discursivas Y, Z, W', por exemplo.” (BARONAS; AGUIAR, 2009, p. 168). Aproximando tal perspectiva teórica aos dados de nosso corpus, ao postular que os "negros" são pessoas capacitadas, notamos o processo de se dizer $\mathrm{X}$, mas querer significar Y: o sujeito deixa de dizer que pode ser possível considerar que os "negros" não sejam pessoas capacitadas e que eles não possuem habilidades intelectuais, o que está vinculado aos dizeres de que "todo nego é ignorante" (recorte 12). De acordo com Tfouni (1995), o processo de constituição histórica do sujeito do discurso e dos sentidos possíveis de serem veiculados em determinada época representam o interdiscurso e notamos a relação com o interdiscurso, pois o sujeito do recorte abaixo quer marcar que essa fala é de outrem:

\section{Recorte 12}

E mesmo hoje em pleno século XXI os negros ainda sofrem com o pré-conceito e de que 'todo nego é ignorante' e que são incapazes de adquirir uma vaga em universidades, mas as faculdades, universidades, ela sempre vão ser ocupada pelos melhores alunos, esse sistema foi só mas um, onde negros e pobres são capaz de conquistar o que querem e podem provar de que cor da pele não influencia em no caráter e muito menos na inteligência. (Um estúpido esteriótipo). 
No recorte 12, há o discurso sobre a capacidade dos afrodescendentes, para o sujeito se posicionar, favoravelmente, às cotas raciais. $\mathrm{O}$ recorte 12 inicia com o enunciado "E mesmo hoje em pleno século XXI" com o intuito de estabelecer uma relação temporal, porque em séculos anteriores os afrodescendentes sofriam preconceitos, mas isso era abertamente aceito pela sociedade. É importante observarmos essa relação temporal, porque, na seção 4.3 há discursos que se sustentam, favoravelmente, às cotas devido a escravidão dos afrodescendentes no Brasil.

\subsection{Argumentos favoráveis às cotas}

Relacionar o conceito de arquivo às analises discursivas dos textos dos sujeitosalunos se faz necessário, pois a

[...] memória institucional ou a que chamo memória de arquivo ou simplesmente o arquivo, é aquela que não esquece, ou seja, a que as Instituições (Escola, Museu, políticas públicas, rituais, eventos etc.) praticam, alimentam, normatizando o processo de significação, sustentando-o em uma textualidade documental, contribuindo na individualização dos sujeitos pelo Estado, através dos discursos disponíveis, à mão, e que mantêm os sujeitos em certa circularidade (ORLANDI, 2010, p. 9).

De acordo com Orlandi (2012) a memória de arquivo é normatizada pelas instituições (como, por exemplo, a escola) que favorecem a individualização dos sujeitos pelo Estado e essas instituições são responsáveis por mantê-los em certa circularidade. Concordamos com a autora e reconhecemos que a partir do acesso ao arquivo escolar não apenas os sujeitos podem estar em circularidade, mas também os seus discursos. Diante disso, constatamos que os sujeitos-alunos que argumentam a favor das cotas acessam mais o arquivo e utilizam conhecimentos históricos, provavelmente, didatizados pelo Aparelho Ideológico de Estado, sobre os séculos de escravidão no Brasil. De modo geral, os textos asseguram que o país tem uma dívida social com os afrodescendentes e as cotas representariam uma possível reparação histórica. O texto abaixo, publicado anos após a assinatura da Lei Áurea, mostra-nos fatos históricos referentes ao tratamento direcionado aos afrodescendentes: 
O negro, quase completamente selvagem, comprado dos feitores africanos e transportado à costa do Brasil pelos traficantes portugueses até a metade do último século, chegava aqui no estado de mais completo embrutecimento que é possível decair uma raça humana. Os aventureiros que exploravam nesta época as terras férteis do Brasil lhes tratavam pior do que animais domésticos, infligindo-lhes provas das mais crueis e humilhantes. Durante a travessia do Oceano, ao menor sinal de rebelião, eles os sufocavam no porão dos navios, fechando as escotilhas e despejando, nesta atmosfera confinada, sacas de cal. Uns morriam de fome, outros de sede, outros ainda asfixiados por suas próprias emanações que, em grande quantidade, viciavam o ar ambiente. (LACERDA, 1911, p. 3)

No início da citação, Lacerda (1911) caracteriza o "negro" como "quase completamente selvagem". Questionamos os sentidos possíveis atribuídos à palavra "selvagem", pois pode estar embutida a hierarquização de um grupo social em detrimento do outro; nesse caso, implicitamente, a cultura africana é retratada de modo inferiorizado em relação à cultura portuguesa e europeia. De modo peculiar, o autor constata que os africanos sofreram física e emocionalmente, pois eram submetidos a "provas das mais cruéis e humilhantes" e que " Uns morriam de fome, outros de sede". As ideias descritas acima sobre os negros permeavam os discursos de alguns sujeitosalunos presentes em nosso corpus.

\section{Recorte 13}

Portanto, as cotas raciais são apenas um motivacional e impulsionador para que esses negros possam tem um vida digna pois por muito tempo, desde os primórdios da sociedade capitalista, esta lhes foi arrancada brutalmente ferindo não somente a carne nos açoites, mas principalmente a alma, a ética e moral destes pobres negros. (Reenbolço Histórico).

\section{Recorte 14}

Quando os portugueses chegaram ao Brasil os índios já se encontravam no país. Depois houve importação de uma grande quantidade de escravos. (Nada mais que justo).

O enunciado "primórdios da sociedade capitalista" e o título do recorte 13 ("Reenbolço Histórico") podem significar que as cotas representam um ressarcimento aos afrodescendentes. Os sentidos de rebaixamento e humilhação podem ser 
relacionados com o trecho do texto de Lacerda (1911): "provas das mais crueis e humilhantes" visto que no recorte 13 aparece: "lhes foi arrancada brutalmente ferindo não somente a carne nos açoites, mas principalmente a alma, a ética e moral destes pobres negros.", tais trechos denunciam as crueldades realizadas contra os afrodescendentes. Ainda que esse discurso seja de valorização às cotas, notamos um possível distanciamento do sujeito em relação aos cotistas por meio da utilização do pronome demonstrativo "destes" e também outra referência pejorativa ao aspecto financeiro por meio da palavra "pobres".

Acerca do aspecto econômico, Althusser (1971, p. 26-27) postula que a sociedade é determinada em última instância pelo econômico, ou seja, ela é pautada por uma base economia (infraestrutura). A base econômica estabelecida pelos portugueses autorizava a comercialização de africanos, escravizados no Brasil. O texto de Lacerda (1911) retrata esse fato histórico "O negro [...] comprado dos feitores africanos e transportado à costa do Brasil" e esse sentido aparece também no recorte 14 em "houve importação de uma grande quantidade de escravos.". Podemos perceber que o afrodescendente é discursivizado como uma mercadoria e não como um cidadão.

\section{Recorte 15}

Alguns dizem ser preconceito, que essas cotas servem apenas para dizer que os negros, pardos e indígenas não possuem capacidade intelectual para entrar em uma universidade. Porém, tais cotas foram criadas com o intuito de amenizar a dívida histórica do Brasil com essas etnias e as diferenças sociais em tais. (Cotas: um meio de oportunidade aos afrodescendentes).

\section{Recorte 16}

A reserva de vagas para alunos de cotas raciais, foi um meio de recompensar seu passado histórico, em que adquire novas chances de estudo, podendo mostrar que são capazes de ser bons alunos, independente de seu passado e de sua cor de pele. (A solução para um consequência).

\section{Recorte 17}

Um assunto bastante discutido são as cotas raciais em universidades públicas brasileiras. Que acaba por ser uma forma de compensar à toda humilhação que o negro 
sofreu no país uma medida para as classes menos favorecidas possuam uma qualidade de ensino vida e que insira o negro no mercado de trabalho.

As cotas raciais levam consigo a chance para esses negros pobres conseguirem alcançar uma edução de qualidade gratuitamente.

A lei de cotas raciais em universidades públicas brasileiras grande valor, portanto, precisa ter continuidade para que cada vez sociedade de torne igualitária, pois todos possuem os mesmos direitos independente da raça. (Igualar oportunidades).

O recorte 15 argumenta que as cotas têm a função de "amenizar a dívida histórica" do Brasil com as denominadas "essas etnias" e as minimizar as diferenças sociais. O pronome demonstrativo "essas" pode indiciar um distanciamento do sujeitoaluno em relação ao grupo que ainda é discriminado. A mesma escolha, ou seja, a escolha pronominal, ocorre no recorte 17 no enunciado "esses negros pobres". No recorte 17, notamos, novamente um discurso que tenta defender o direito dos afrodescendentes, entretanto, caracteriza o "negro" apenas como pobre e necessitado de políticas afirmativas com recorte racial.

No recorte 16, temos o enunciado que faz referência à cor da pele, isso pode ter aparecido porque 'O 'preconceito de cor' é condenado sem reservas, como se constituísse um mal em si mesmo, mais degradante para quem o pratique do que para quem seja vítima" (FERNANDES, 2007, p. 41). O recorte indica que os afrodescendentes podem ser bons alunos mesmo diante de seu passado e da cor de sua pele.

Portanto, os recortes desta seção 4.3 indiciam o discurso do sujeito-aluno que tenta defender que: "É preciso que se compreenda que uma sociedade nacional não pode ser homogênea e funcionar equilibradamente sob a permanência persistente de fatores de desigualdade." (FERNANDES, 2007, p. 52), ou seja, eles se mostram favoráveis à política de cotas, pois veem nelas um meio para a diminuição das desigualdades.

De modo geral, as referências históricas não aparecem na FD contrária à política afirmativa. Os sentidos legitimados sobre o passado dos afrodescendentes constituem a FD dominante nos recortes analisados; todavia, não há discussão e argumentação sobre a constituição sócio-histórica dos sentidos sobre escravidão. Apesar de os sujeitosalunos escreverem seus textos no século XXI, há 128 anos após o término oficial da escravidão brasileira, eles não conseguiram questionar a vinculação do afrodescendente a seu passado, o que indica que, pela força da memória discursiva, o afrodescendente 
ainda é discursivizado como fora outrora: inferior. Isso ocorre porque o presente não é diferente do passado e o retorno recorrente funciona como um discurso de justificativa para defender o direito dos afrodescendentes.

\subsection{Argumentos desfavoráveis às cotas}

Podemos caracterizar a mídia como uma instituição eficaz em materializar sentidos. Althusser (1971), por meio da sua teoria sobre os Aparelhos Ideológicos de Estados, caracterizou o que podemos denominar mídia como "AIE da informação (imprensa, radio, televisão, etc.)" (ALTHUSSER, 1971, p. 44). Reconhecemos que esse AIE atua de modo predominante na sociedade contemporânea brasileira por meio de um discurso dominante, tornando-se, possivelmente, o AIE mais efetivo.

Não vemos a mídia como uma transmissora, que apenas divulga uma informação de modo neutro e referencial. Pelo contrário, em consonância com Oliveira (2012, p. 59) defendemos que esse AIE está instituído simbolicamente e presente no imaginário social, com a sua especificidade histórica e se mostra como um meio de produção de efeitos de sentidos que são aceitos pela FD dominante. É preciso estudar mais sobre interpelação midiática visto que há “[...] o discurso jornalístico como modalidade de discurso sobre. Um efeito imediato do falar sobre é tornar objeto aquilo o que se fala [...]. Os discursos sobre são discursos que atuam na institucionalização de sentidos." (MARIANI, 1999, p. 60). Reconhecemos a imprensa como grande materializadora de efeitos de sentidos por meio da institucionalização deles, por meio da direção e homogeneização de intepretações.

Foi por meio da mídia ${ }^{5}$ que muitos sujeitos tiveram acesso a sentidos vinculados às cotas raciais e, talvez, também, por meio dela que foram capazes de "formar sua opinião" sobre o assunto. Assumimos essa possibilidade diante do fato de que a Revista Veja, que de acordo com o site da ANER1 (Associação Nacional de Editores de Revistas) de janeiro a setembro 2014 foi a revista mais vendida do Brasil (1.167.928 de exemplares), discursiviza, frequentemente, contra as cotas. A título de exemplo, citamos o texto presente em nossa coletânea, "O grande erro das cotas", de Julia Carvalho (Anexo E) que foi publicado no site da revista e apresenta argumentos desfavoráveis a

\footnotetext{
${ }^{5}$ Acesso ao site da ANER. Disponível em <http://aner.org.br/dados-de-mercado/circulacao/> Em $17 / 07 / 2016$, às $12 \mathrm{~h} 13 \mathrm{~min}$.
} 
essa política afirmativa. Nossos recortes apresentam sentidos que se filiam à FD da Veja.

\section{Recorte 18}

É como se os afrodecendentes não possuíssem condições ou capacidade de ingressa ao ensino superior sem ajuda, menosprezando a capacidade desse grupo, essa lei age de forma preconceituosa ( "Cotas" Beneficio ou ilusão? ).

\section{Recorte 19}

As cotas raciais são extremamente desnecessárias em universidades ou qualquer outro

lugar. É como um insulto aos negros, como se não soubessem nada, como se não tivesse, a mesma capacidade de um branco. (Não às cotas).

\section{Recorte 20}

Não acho justo que os alunos negros tenham vagas garantidas, sem mérito. Isso gera mais preconceito e desigualdade, tendo em vista que esses alunos não competem de igual para igual na hora do vestibular. (As cotas raciais: defender ou criticar).

O sujeito-aluno do recorte 18 acusa a política de cotas de ser "preconceituosa", pois não valoriza a capacidade do cotista. O sujeito-aluno do recorte 19 é mais incisivo ao defender que essa política é um "insulto aos negros" e deixa implícito que o "negro" tem "a mesma capacidade de um branco". O último recorte, 20, tem um sujeito-aluno que se manifesta pessoalmente ("acho") e se volta para o juridismo ao afirmar "não é justo que os negros tenham vagas garantidas, sem mérito.” Nesses recortes - 18, 19 e 20 - há sentidos desfavoráveis à política de cotas raciais e os sujeitos reconhecem a lei como preconceituosa, um insulto aos afrodescendentes e injusta.

Finalizamos este capítulo com a citação das conclusões gerais da pesquisa de Oliveira (2012, p. 6) intitulada "O discurso sobre cotas para negros na Revista Veja”. A partir da leitura tecemos nossos comentários sobre a citação em paralelo com os sentidos apontados nas análises precedentes. Segue alguns apontamentos da pesquisa:

ancorada nos pré-construídos da democracia racial, do mérito individual aliado ao da igualdade jurídica, Veja se opõe às cotas para negros e, para isso, mobiliza o discurso de especialistas e de negros 
contrários às cotas e o discurso científico, silenciando as reivindicações dos movimentos pró-cotas e apontando para outras alternativas que possibilitem a inserção dos negros que desconsideram as cotas. Produzindo, portanto, os efeitos de sentidos do "perigo", do "risco", da ingerência política e "ideológica" do governo federal "petista", da "racialização" do país. Nesse processo, o negro é produzido imaginariamente de maneira dual, bom ou mal, de acordo com as posições discursivas ocupadas pelo periódico. (OLIVEIRA, 2012, p.6).

Essa citação é consonante à análise de vários recortes presentes nesta seção, pois percebemos que os sentidos postulados pelo semanário perpassam o nosso corpus de modo predominante. Os sentidos de democracia racial, do mérito individual aliado ao da igualdade jurídica difundidos pela revista, de acordo com Oliveira (2012), foram muito recorrentes e poderíamos dizer que houve também uma tentativa de paráfrase desses sentidos. O sujeito-aluno, de modo geral, não se referiu ao discurso de especialistas, nem tampouco ao discurso científico para sustentar sua argumentação. Todavia em nosso corpus as reivindicações do movimento pró-cotas, assim como na revista, foram silenciadas. Por outro lado, os sentidos que reconhecem as cotas como uma política afirmativa criada no governo do PT (Partido dos Trabalhadores) não foram mencionadas: os sujeitos apenas citaram/criticaram a imposição dessa lei, mas não apresentaram um crítica ao partido político que implementou essa política afirmativa.

Tínhamos a hipótese de que os alunos das escolas públicas participantes da pesquisa seriam predominantemente favoráveis às cotas, visto que, de um modo ou de outro, eles também são beneficiados por essa política. A USP (Universidade de São Paulo), por exemplo, disponibiliza alguns métodos alternativos de ingresso na universidade com a reserva mais vagas para discentes oriundos do sistema público de ensino do que para os afrodescendentes). Entretanto, notamos, predominantemente, um discurso que se posiciona contra as cotas e que os alunos argumentam pouco sobre esse tema polêmico. Dessa forma, questionamos: como o aluno conseguiria argumentar sendo afetado por dois aparelhos ideológicos tão fortes: a escola e a mídia?

Notamos, então, que

[...] nunca se sai de uma região para se entrar em outra: não se rompe jamais com a ideologia em geral, mas sempre com esta ou aquela formação ideológica, inscrita histórico-materialmente no conjunto 
complexo das formações ideológicas de uma formação social dada. (PÊCHEUX, 1988, p. 28)

Por fim, ressaltamos que os sentidos presentes nesse trabalho não são cristalizados, porque uma seção tem elementos que podem aparecer também em outro recorte presente em outra parte do capítulo. E em consonância com a $\mathrm{AD}$, constatamos que os sentidos não são homogêneos e lineares.

A seguir trazemos algumas considerações referentes ao nosso estudo. 


\title{
CONSIDERAÇÕES
}

\author{
I have a dream today! ${ }^{6}$ \\ Martin Luther King \\ (KING, 1968, p.30)
}

Esta dissertação de mestrado teve como objetivo propiciar a discussão sobre as cotas raciais na instituição escolar por meio do diálogo com os sujeitos-alunos, realizado tanto em sala de aula, diretamente com eles, quanto por meio das análises dos textos dissertativo-argumentativos por eles produzidos.

Se por um lado, aqui, posicionamo-nos discursivamente nos capítulos anteriores, predominantemente, como sujeito-pesquisador, por outro lado, não podemos negar que reflexões imprescindíveis dessa pesquisa foram realizadas com base em nossa experiência docente. $\mathrm{Na}$ verdade, um dos motivos para tecermos nosso trabalho é entendermos que o estudo irá contribuir para a nossa prática em sala de aula, pois é na educação básica que encontramos motivação para aprender constantemente e marcarmos nossa contribuição para a educação de um cidadão político que reconhece a sua importância histórica, ideológica e social. Apesar de termos enfrentado dificuldades na pesquisa, especialmente, para constituirmos o nosso corpus, defendemos que o pósgraduando, sobretudo das universidades públicas, cujas pesquisas são sustentadas pela sociedade, podem e devem contribuir para melhorar a escola e a esfera social.

Problematizar a questão da existência do racismo no Brasil, por meio da implementação das cotas raciais, é algo que suscitou resistência de alguns sujeitos, entretanto, explicitarmos e compreendermos, academicamente, o preconceito e os sentidos que circulam sobre ele nas diferentes formações discursivas é uma etapa primordial para a mudança dessa realidade.

Em relação ao corpus, notamos uma saturação do repetível e diversos textos não apresentaram a estrutura dissertativa, tampouco seguiram as regras da norma culta da Língua Portuguesa, o que pode indiciar que os sujeitos-alunos não conhecem esses conteúdos escolares, ou ainda, que marcam resistência em relação ao uso dessa variedade linguística. Tínhamos a hipótese de que os sujeitos, por serem alunos da rede pública de ensino, que podem ser beneficiados pelas cotas, iriam argumentar, favoravelmente, a essa ação afirmativa. Contudo, muitos textos se mostraram contrários

\footnotetext{
${ }^{6}$ Eu tenho um sonho hoje! (KING, 1968, p. 30, tradução nossa)
} 
a implementação da Lei $n^{\circ} 12.711$, sustentando-se na afirmação do discurso jurídico, com sentidos parafrásticos, de que "todos são iguais perante a lei"; portanto, as cotas não são necessárias. Nesse caso, constatamos uma contradição, como postulou Pêcheux (1988), uma vez que os sujeitos usam a lei que determina a igualdade para negar a lei que assegura o direito à universidade para pessoas que são tratadas, pela sociedade, de modo desigual, e isso pode indicar uma alienação. Há nessa contradição o funcionamento da ideologia criando a evidência de que "todos são iguais perante a lei" e a ilusão de que o sentido só pode ser um, portanto o sujeito não duvida da (des)igualdade e posiciona-se, contrariamente, à lei que visa a criar possibilidades mais igualitárias para os vestibulandos. E o discurso jurídico que poderia representar uma ruptura desse sentido dominante, na verdade, por meio da aparência de igualdade da sociedade capitalista, sustenta relações desiguais. O Estado reconhece que as políticas universalizantes não atendem a população afrodescendente, sendo assim, dizem tentar alterar essa realidade por meio das políticas afirmativas e valorativas; todavia, não apresentam orientações concretas para essas implementações e temos dúvidas se as diretrizes são plenamente aplicadas.

Constatamos que há na escola a repetição do discurso midiático e a falta de acesso do sujeito-aluno ao arquivo (PÊCHEUX, 1997) e poucos questionamentos acerca da realidade social e econômica dos afrodescendentes, assim, o discurso dominante sobre esse grupo age por meio da memória discursiva e da ideologia, de forma que os discursos dos sujeitos-alunos se sustentam pelos dizeres do branco em relação ao afrodescendente, de modo que os sentidos de desigualdade, inferioridade e incapacidade são recorrentes: é difícil romper com essa constituição sócio-histórica. Em outras palavras, nossa pesquisa aponta para a falta de uma discussão adensada sobre as cotas raciais no Ensino Médio, essa discussão poderia ocorrer por meio da argumentação. Na escola, há poucos momentos que possibilitam a argumentação, visto que a paráfrase é mais valorizada. Apesar de Pacífico (2016) defender que a argumentação é um direito humano, vemos, nesse contexto, que esse direito é negado aos sujeitos-alunos. E o resultado dessa negação pode ser vista na escrita que não se sustenta pela prática discursiva argumentativa.

Por outro lado, há discursos que, por meio de sentidos legitimados sobre o passado histórico brasileiro, sustentam que as cotas são necessárias como meio de reparação social devido à escravização dos afrodescendentes e de modo geral as referências históricas não aparecem na FD contrária à política afirmativa. Tal discurso 
mostra que o presente não é totalmente distinto do passado e o retorno recorrente funciona como um discurso de justificativa para defender $o$ direito dos afrodescendentes. Além disso, esses textos apresentavam o afrodescendente como necessitado das cotas e alguns demonstram um distanciamento por meio do uso de pronomes demonstrativos. Mesmo sendo favoráveis à ação afirmativa, nem um texto apresentou a voz de luta e resistência do Movimento Negro Brasileiro, o que aponta para o silenciamento do afrodescendente que possui práticas políticas e sociais para melhorar a sociedade.

De acordo com as reflexões apresentadas, defendemos que as cotas raciais bem como o racismo no Brasil merecem mais estudos. Além disso, reiteramos que a lei deve ser mais problematizada nas escolas e discutida por aqueles sujeitos que serão diretamente afetados por essa política. Esperamos que o embasamento teórico desta pesquisa, as relações tecidas com base na realidade escolar e as análises apresentadas, neste trabalho, sejam importantes para outros pesquisadores e professores refletirem acerca das questões do discurso, do preconceito, das cotas raciais e das desigualdades sociais que se sustentam em discursos produzidos há séculos, em terras brasileiras. 


\section{REFERÊNCIAIS}

ALTHUSSER, L. Sobre a Reprodução. Petrópolis: Editora Vozes, 1999.

Resposta a John Lewis, in Posições I. Rio de Janeiro: Edições Graal, 1978.

Aparelhos Ideológicos de Estado. Biblioteca Universal Presença/Martins Fontes. Lisboa. Tradução Joaquim José de Moura Ramos, 1971.

ALVARENGA, M. Apontamentos de metodologia para a ciência e técnicas de redação científica. Porto Alegre: Sergio Antônio Fabris Ed., 2003.

AMOSSY, Ruth. Argumentação e Análise do Discurso: perspectivas teóricas e recortes disciplinares. Tradução de Eduardo Lopes Piris e Moisés Olímpio Ferreira. EID\&A - Revista Eletrônica de Estudos Integrados em Discurso e Argumentação, Ilhéus, n.1, p. 129-144, nov. 2011.

O lugar da argumentação na análise do discurso: abordagens e desafios contemporâneos. Filol. lingüíst. port., n. 9, p. 121-146, 2007.

ARISTÓTELES. Retórica. Tradução de Edson Bini. São Paulo: EDIPRO, 2011.

AUTHIER-REVUZ, J. Palavras incertas: as não coincidências do dizer. Tradução de Claudia Pfeiffer et al. Campinas: Editora UNICAMP, 1998.

BANDEIRA, M. Poesia e Prosa. Rio de Janeiro: Nova Aguilar, 1986.

BARONAS, R. Ensaios em Análise de Discurso: questões analítico-teóricas. São Carlos: EDUFSCar, 2011.

BARONAS, R.; AGUIAR, G. Do acontecimento histórico ao acontecimento discursivo: o político na charge. Bakhtiniana, São Paulo, v. 1, n. 2, p. 165-182, 2009.

BIBLIA. Português. Bíblia sagrada. Tradução: Centro Bíblico Católico. 26. ed. rev. São Paulo: Ave Maria, 2000. 1 Samuel 7:12.

BOGDAN, R.; BIKLEN, S. Investigação Qualitativa em Educação: uma introdução à teoria e aos métodos. Porto: Ed. Porto, 1994.

BRASIL. Constituição da República Federativa do Brasil de 1988. Disponível em <http://www.planalto.gov.br/ccivil_03/Constituicao/Constituicao.htm.> Acesso em: 20 nov. 2015.

BRASIL. Lei $n^{\circ} 10.639$, de 9 de janeiro de 2003. Altera a Lei no 9.394, de 20 de dezembro de 1996, que estabelece as diretrizes e bases da educação nacional, para incluir no currículo oficial da Rede de Ensino a obrigatoriedade da temática "História e Cultura Afro-Brasileira", e dá outras providências. Diário Oficial da União, Brasília, DF, 10 jan. 2003. Disponível em <http://www.planalto.gov.br/ccivil_03/leis/2003/L10.639.htm> Acesso em: 04 abr. 2015. 
BRASIL. Lei $\mathrm{n}^{\circ}$ 12.711, de 29 de agosto de 2012. Dispõe sobre o ingresso nas universidades federais e nas instituições federais de ensino técnico de nível médio e dá outras providências. Diário Oficial da União, Brasília, DF, 30 ago. 2012.

BRASIL. LEI No 3.353, DE 13 DE MAIO DE 1888.Declara extinta a escravidão no Brasil. Disponível em <http://www.planalto.gov.br/ccivil_03/leis/LIM/LIM3353.htm>Acesso em 24 jul. 2016

BRASIL. PNDHDECRETO No 7.037, DE 21 DE DEZEMBRO DE 2009. Aprova o Programa Nacional de Direitos Humanos - PNDH-3 e dá outras providências.http://www.planalto.gov.br/ccivil_03/_Ato20072010/2009/Decreto/D7037.htm(Acesso em 24/07/2016)

CÂNDIDO, A. O direito à Literatura. In: Vários escritos. São Paulo: Duas Cidades, 1995, p. 169-191.

CASSIN, M. Louis Althusser e o Papel Político/Ideológico da Escola. Tese (Doutorado em Educação) UNICAMP: Campinas, 2002.

CEREJA, W.; MAGAlHÃES, T. Português: linguagens, 3. São Paulo: Saraiva, 2013

CORACINI, M. Nossa língua: materna ou madrasta? - Linguagem, discurso e identidade. In: CORACINI, M. (Org.) A celebração do outro: arquivo, memória e identidade: línguas (materna e estrangeira), plurilinguismo e tradução. Campinas: Mercado de Letras, 2007.

A celebração do outro na constituição da identidade. Organon. Porto Alegre, v. 17, n. 35 , p. 201-220, 2003.

COSTA, C. Políticas de Promoção da Igualdade Racial - o Ministério. Brasília, 26 jun. 2015. Disponível em <http://www.portaldaigualdade.gov.br/sobre-a-seppir/oministerio> Acesso em: 23 ago. 2015.

COUTO, M. Terra Sonâmbula. São Paulo: Companhia de Bolso, 2015.

DAFLON, V..; FEREZ JR., J.; CAMPOS, L. A. Ações Afirmativas Raciais no Ensino Superior Público Brasileiro: um panorama analítico. Caderno de Pesquisa. V.43, n. 148, p.302-327, 2013.

DESLANDES, S. O projeto de pesquisa como exercício científico e artesanato intelectual. In: MINAYO, M. (Org.) Pesquisa social: teoria, método e criatividade. Rio de Janeiro: Vozes, 2010.

EL@DIS. III jornada do El@ dis: Metodologias em Discurso- CIRP-USPRP. 2012.

FARIA, D. Filtros na rede: das relações entre discurso e tecnologia. Tese (Doutorado em Psicologia) Universidade de São Paulo Ribeirão Preto, 2016.

FEREZ JUNIOR, J.; DAFLON, V. F.; BARBABELA, E. As Políticas de Ação Afirmativa nas universidades estaduais. Levantamento de Políticas de Ação Afirmativa (GEMAA), IESP-UERJ, 2013, p. 1-25. 
FERNANDES, F. O negro no mundo dos brancos. São Paulo: Global editora, 2007. p. 38-63.

A integração do negro na sociedade de classes. São Paulo: Ática, 1978.

FIORIN, J. Argumentação. São Paulo: Contexto, 2015.

FOLHA DE SÃO PAULO. Taxa de pobreza é mais alta entre negros. Cotidiano, São Paulo, 30 jun. 2003. Disponível em:

http://www1.folha.uol.com.br/folha/cotidiano/ult95u77642.shtml

FOUCAULT, M. A arqueologia do saber. Tradução Luiz Felipe Baeta Neves. Rio de Janeiro: Forense Universitária, 1995.

FREGE, G. Lógica e Filosofia da linguagem. Tradução Paulo Alcoforado. São Paulo: Cultrix e Edusp, 1978.

FREUD, C. Le mot d'esprit et ses rapports avec l'inconscient (1905). Paris: Guallimard, 1971.

Os chistes e sua relação com o inconsciente. Tradução Margarida Salomão, sob direção de Jayme Salomão. Rio de Janeiro: Imago, 1977.

GALVÃO, T. O Calhambola. In: SECCHIN, A. (Sel.)/ Romantismo. São Paulo: Global, 2007 [1898].

GARCIA, R. Novos olhares sobre a alfabetização. São Paulo, Cortez, 2008.

GINZBURG, C. Sinais: Raízes de um Paradigma Indiciário. In: GINZBURG, C. (Orgs.) Mitos, Emblemas, Sinais: Morfologia e História. Tradução Frederico Carotti. São Paulo: Companhia das Letras, 2002 [1980]. p. 143-179.

GIROUX, P. Pedagogia radical. São Paulo: Cortez-Autores associados, 1983.

GRIGOLETTO, E.; AGUSTINI, C. A autoria na escrita de adolescentes: interfaces entre o virtual e o escolar. In: INDURSKY, F; FERREIRA, M. C. L.; MITTMANN, S. (org.) $\mathrm{O}$ discurso na contemporaneidade: materialidades e fronteiras. São Carlos: Claraluz, 2009. p. 369-380.

HAROCHE, C. Fazer dizer, querer dizer. São Paulo: Ed. Hucitec, 1992.

HOLANDA, C. Apesar de você [Compositor] In. Chico 50 Anos - O Político Chico Buarque - São Paulo. Universal Music 1991 (1970) Faixa 2 (3min 54 s)

KING, M. The Peaceful Warrior Nova Iorque: Pocket Books, 1968.

LACAN, J. Les Quatre Concepts foundamentaux de la psychanalyse. Paris: Seuil, 1979.

LACERDA, J. Sobre os Mestiços. Primeiro Congresso Internacional das Raças. Londres, 1911. 
LAGAZZI, S. Algumas considerações sobre o método discursivo. In: O desafio de dizer não. Campinas: Pontes, 1988.

LEMES, N. Argumentação, livro didático e discurso jornalístico: vozes que se cruzam na disputa pelo dizer e silenciar. Dissertação de Mestrado. FFCLRP/USP, julho 2013.

LOPES, A. Políticas de educação, educação como política: observações sobre a ação afirmativa como estratégia política. In: SILVA, P.; GONÇALVES, B.; SILVÉRIO, V. Educação e ações afirmativas: entre a injustiça simbólica e a injustiça econômica Brasília: Instituto Nacional de Estudos e Pesquisas Educacionais Anísio Teixeira, 2003.

MACHADO, A. (1917) Caminante no hay camino. Poemas y cantares, 36. (1999).Acesso em 24.07.2016 http://www.poemas-del-alma.com/antonio-machadocaminante-no-haycamino.

MAINGUENEAU, D. L'analyse du discours et ses fronteires. Marges linguistiques, $\mathrm{n}$. 9 M.L.M.S. Éditeur, Saint-Chamas, France, 2005.

Novas tendências em análise do discurso. São Paulo: Pontes, 1993.

MARANGONI, E. Discurso de divulgação científica e efeito-leitor: o apagamento de si e de leituras possíveis. Dissertação de Mestrado. FFCLRP/USP, 2013.

MARIANI, B. O PCB e a imprensa. Campinas: Editora da UNICAMP, 1999.

MARX, K.; ENGELS, F. A Ideologia Alemã. Lisboa: Editorial Presença, 1980.

MINAYO, M. Trabalho de campo: contexto de observação, interação e descoberta. In: MINAYO, M. (Org.) Pesquisa social: teoria, método e criatividade. Rio de Janeiro: Vozes, 2010.

O desafio do conhecimento: pesquisa qualitativa em saúde. São Paulo: HUCITEC, 2008.

MINAYO, M.; SANCHES, O. Quantitativo-Qualitativo: oposição ou complementaridade. Cadernos de Saúde Pública. Rio de Janeiro, v. 9, n. 3, p. 239262. 1993 [1983].

MUNANGA, K. A difícil tarefa de definir quem é negro no Brasil. Estudos

Avançados. São Paulo, v.18, n.50, p.51-66. Abril, 2004. . Disponível em $<$ http://www.scielo.br/scielo.php?script=sci_arttext\&pid=S0103$40142004000100005 \& \operatorname{lng}=$ en\&nrm=iso > . Acesso em 25 jul. 2016

NEGRO (Google)- Nota Página do Goggle, Elaboração própria. Acesso em 22/06/ 2016, às 13 h e 29 min.

OLIVEIRA, L. O discurso sobre as cotas para negros na revista Veja. UNIOESTE: Cascavel, 2012.

ORLANDI, E. A linguagem e seu funcionamento: as formas do discurso. Campinas: Pontes, 2011. 
As formas do silêncio: no movimento dos sentidos. Campinas: Editora, 2007.

Análise de discurso: princípios e procedimentos. Campinas: Pontes, 2001.

Discurso e Leitura. São Paulo: Cortez, 1996.

. O lugar das sistematicidades linguísticas na Análise do Discurso. D.E.L.T.A. Vol. 10, n 2, 1994, p. 295-307.

Paráfrase e Polissemia: a fluidez nos limites do simbólico. Revista do Núcleo de Desenvolvimento da Criatividade. n.04. Campinas: UNICAMP, 1998.

PACÍFICO, S. O direito à argumentação no contexto escolar. In: PIRIS, E.; OLÍMPIOFERREIRA, E. (Orgs.) Discurso e Argumentação em múltiplos enfoques. 2016. Coimbra: Grácio Editor, 2016. p. 191- 226.

Argumentação e autoria nas redações de universitários: discurso e silêncio.

Curitiba: Appris, 2012.

PAIXÃO, M.; ROSSETTO, I.; MONTOVANELE, F.; CARVANO, L. M. (Orgs.)

Relatório Anual das Desigualdades Raciais no Brasil; 2009-2010.

PÊCHEUX, G.; GADET, F. A língua inatingível. In: ORLANDI, E.P. Análise de Discurso: Michel Pêcheux. Campinas-SP: Pontes, 2011 [1981].

PÊCHEUX, M. Semântica e discurso: uma crítica à afirmação do obvio. Tradução Eni Puccinelli Orlandi et al. Campinas: UNICAMP, 2014 [1988].

O discurso: estrutura ou acontecimento. Tradução Eni Puccinelli Orlandi. Campinas: Pontes, 2012 [1997].

Papel da memória/ Pierre Achard ( et al.): Tradução José Horta Nunes. Campinas: Pontes, 1999. 1997.

Ler o arquivo hoje. In: ORLANDI, E. Gestos de Leitura. Campinas: Pontes,

PÊCHEUX, M.; FUCHS, C. A propósito da análise automática do discurso: atualização e perspectivas. In: GADET, F.; HAK, T. Por uma análise automática do discurso: uma introdução à obra de Michel Pêcheux. Tradutores Bethania S. Mariani et al. Campinas UNICAMP, 1990.

PÊCHEUX, M.; HAROCHE, C.; HENRY, P. A semântica e o corte saussuriano: língua, linguagem, discurso. In: BARONAS, R. Análise do discurso: apontamentos para uma história da noção conceito de formação discursiva. São Carlos: Pedro \& João Editores, 2007.

PERELMAN, C.; OLBRETCHTS-TYTECA, L. Tratado da Argumentação. A Nova Retórica. São Paulo: Martins Fontes, 1996. [1958] 
Plano Nacional de Educação em Direitos Humanos (PNDH-3) / Comitê Nacional de Educação em Direitos Humanos. - Brasília: Secretaria Especial dos Direitos Humanos, Ministério da Educação, Ministério da Justiça, UNESCO, 2010.

PLANTIN, C. Análise e crítica do discurso argumentativo. Tradução de Rodrigo dos Santos Mota; Sébastien Giuliano Giancola; Thaise Almeida dos Santos. Revisão da tradução de Moisés Olímpio Ferreira; Sérgio Israel Levemfous. EID\&A - Revista Eletrônica de Estudos Integrados em Discurso e Argumentação, Ilhéus, n.1, p. 1737, nov. 2011.

Revista Arquitetura da Redação/Universidade Estadual de Ponta Grossa. Coordenação Geral e Pedagógica da Comissão Permanente se Seleção CPS/ UEPG. (outubro de 2013)- Ponta Grossa UEPG, 2013 v. 1. Disponível em: <http://www.laeser.ie.ufrj.br/PT/relatorios\%20pdf/Relat\%C3\%B3rio_2009-2010.pdf> Acesso em: 23 ago. 2015.

ROCHA, E.; ROSEMBERG, F. Autodeclaração de cor e raça entre os escolares paulistanos (as). Cadernos de Pesquisa, v. 37, n. 132, p. 759-799, set./dez. 2007.

ROCHA, J. Teologia e Negritude. Santa Maria: Pallotti, 1998.

RODRIGUES, A. Escrita e Autoria: entre histórias, memórias e descobertas. Campinas: Mercado das Letras, 2011.

SAVIANI, D. Escola e democracia. Campinas: Autores Associados, 2008.

SCHERER, A.; TASCHETTO, T. O papel da memória ou a memória do papel de Pêcheux para os estudos linguísticos-discursivos. Estudos da Língua(gem): Michel Pêcheux e a Análise do Discurso, Vitória da Conquista, 2005.

SCHONS, C; MITTMANN, S. A contradição e a (re)produção/ transformação na e pela ideologia. In: INDURSKY, F.; LEANDRO FERREIRA, M.; MITTMANN, S. (Orgs.). O discurso na contemporaneidade: materialidades e fronteiras. São Carlos: Claraluz, 2009. p. 295-304.

SILVEIRA, V. Por um acesso fecundo ao arquivo. Letras. Universidade Federal de Santa Maria/PPGL. Jul./Dez, 2000.

SOARES, G. D. Conteúdo sobre África ainda é escasso. EVC/USP/UNIVESP. 2013. Disponível em: <http://evc.prceu.usp.br/?p=492> Acesso em: 06 jul. 2015.Publicado anteriormente no jornal O Estado de São Paulo em 21 de novembro de 2013.

TFOUNI, L. A. Letramento e alfabetização. São Paulo: Cortez, 1995.

UNIVERSIDADE DE BRASÍLIA. Análise do sistema de cotas para negros da Universidade de Brasília. Período: $2^{\circ}$ Semestre de 2004 a $1^{\circ}$ Semestre de 2013. Brasília: Universidade de Brasília, 2013. p. 3-50.

VANDRÉ, G. Pra não dizer que não falei das flores . [Compositor] In. Pérolas. São Paulo: Som Livre . 2000 (1968). 1 LP. Faixa 1 (5 mim 49 s) 
ZONATTO, K.; PACÍFICO, S.; ROMÃO, L.O discurso sobre os portadores de deficiência em documentos oficiais. Linguagem \& Ensino, Pelotas, v.12, n.2, p.419433, jul./dez. 2009.

ZOPPI-FONTANA, M. Retórica e argumentação. In: ORLANDI, E.P.; LAGAZZIRODRIGUES, S. Discurso e Textualidade. Campinas: Pontes, 2010.p. 177-210. 


\section{ANEXO A}

\section{$\frac{1}{\cdots}$ \\ Presidência da República \\ Casa Civil \\ Subchefia para Assuntos Jurídicos \\ LEI N ${ }^{0}$ 10.639, DE 9 DE JANEIRO DE 2003.}

Altera a Lei n⿳⺈ 9.394, de 20 de dezembro de

$\underline{\text { Mensagem de veto }}$ 1996, que estabelece as diretrizes e bases da educação nacional, para incluir no currículo oficial da Rede de Ensino a obrigatoriedade da temática "História e Cultura AfroBrasileira", e dá outras providências.

O PRESIDENTE DA REPÚBLICA Faço saber que o Congresso Nacional decreta e eu sanciono a seguinte Lei:

Art. $1^{\circ}$ A Lei n ${ }^{\circ}$ 9.394, de 20 de dezembro de 1996, passa a vigorar acrescida dos seguintes arts. 26-A, 79-A e 79-B:

"Art. 26-A. Nos estabelecimentos de ensino fundamental e médio, oficiais e particulares, torna-se obrigatório o ensino sobre História e Cultura Afro-Brasileira. $\S 1^{\circ} \mathrm{O}$ conteúdo programático a que se refere o caput deste artigo incluirá o estudo da História da África e dos Africanos, a luta dos negros no Brasil, a cultura negra brasileira e o negro na formação da sociedade nacional, resgatando a contribuição do povo negro nas áreas social, econômica e política pertinentes à História do Brasil.

$\S 2^{\circ}$ Os conteúdos referentes à História e Cultura Afro-Brasileira serão ministrados no âmbito de todo o currículo escolar, em especial nas áreas de Educação Artística e de Literatura e História Brasileiras.

$\S 3^{\circ}$ (VETADO)"

"Art. 79-A. (VETADO)"

"Art. 79-B. O calendário escolar incluirá o dia 20 de novembro como 'Dia Nacional da Consciência Negra'."

Art. $2^{\circ}$ Esta Lei entra em vigor na data de sua publicação.

Brasília, 9 de janeiro de 2003; $182^{\circ}$ da Independência e 115ํํㄹ República. LUIZ INÁCIO LULA DA SILVA

Cristovam Ricardo Cavalcanti Buarque 
ANEXO B

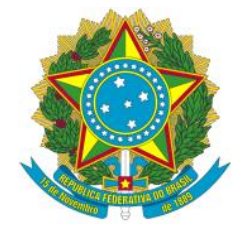

Presidência da República

Casa Civil

Subchefia para Assuntos Jurídicos

LEI No 12.711, DE 29 DE AGOSTO DE 2012.

Dispõe sobre o ingresso nas universidades

federais e nas instituições federais de ensino

técnico de nível médio e dá outras

providências.

A PRESIDENTA DA REPÚBLICA Faço saber que o Congresso Nacional decreta e eu sanciono a seguinte Lei:

Art. $1^{0}$ As instituições federais de educação superior vinculadas ao Ministério da Educação reservarão, em cada concurso seletivo para ingresso nos cursos de graduação, por curso e turno, no mínimo 50\% (cinquenta por cento) de suas vagas para estudantes que tenham cursado integralmente o ensino médio em escolas públicas.

Parágrafo único. No preenchimento das vagas de que trata o caput deste artigo, $50 \%$ (cinquenta por cento) deverão ser reservados aos estudantes oriundos de famílias com renda igual ou inferior a 1,5 salário-mínimo (um salário-mínimo e meio) per capita.

Art. 20 (VETADO).

Art. $3^{\mathrm{o}}$ Em cada instituição federal de ensino superior, as vagas de que trata o art. $1^{\circ}$ desta Lei serão preenchidas, por curso e turno, por autodeclarados pretos, pardos e indígenas, em proporção no mínimo igual à de pretos, pardos e indígenas na população da unidade da Federação onde está instalada a instituição, segundo o último censo do Instituto Brasileiro de Geografia e Estatística (IBGE).

Parágrafo único. No caso de não preenchimento das vagas segundo os critérios estabelecidos no caput deste artigo, aquelas remanescentes deverão ser completadas por estudantes que tenham cursado integralmente o ensino médio em escolas públicas.

Art. $4^{\underline{0}}$ As instituições federais de ensino técnico de nível médio reservarão, em cada concurso seletivo para ingresso em cada curso, por turno, no mínimo 50\% (cinquenta por cento) de suas vagas para estudantes que cursaram integralmente o ensino fundamental em escolas públicas.

Parágrafo único. No preenchimento das vagas de que trata o caput deste artigo, $50 \%$ (cinquenta por cento) deverão ser reservados aos estudantes oriundos de famílias com renda igual ou inferior a 1,5 salário-mínimo (um salário-mínimo e meio) per capita.

Art. $5^{\circ}$ Em cada instituição federal de ensino técnico de nível médio, as vagas de que trata o art. $4^{\circ}$ desta Lei serão preenchidas, por curso e turno, por autodeclarados pretos, pardos e indígenas, em proporção no mínimo igual à de pretos, pardos e indígenas na população da unidade da Federação onde está instalada a instituição, segundo o último censo do Instituto Brasileiro de Geografia e Estatística (IBGE).

Parágrafo único. No caso de não preenchimento das vagas segundo os critérios estabelecidos no caput deste artigo, aquelas remanescentes deverão ser preenchidas por estudantes que tenham cursado integralmente o ensino fundamental em escola pública.

Art. 6 ${ }^{\circ}$ O Ministério da Educação e a Secretaria Especial de Políticas de Promoção da Igualdade Racial, da Presidência da República, serão responsáveis pelo 
acompanhamento e avaliação do programa de que trata esta Lei, ouvida a Fundação Nacional do Índio (Funai).

Art. $7^{\underline{0}}$ O Poder Executivo promoverá, no prazo de 10 (dez) anos, a contar da publicação desta Lei, a revisão do programa especial para o acesso de estudantes pretos, pardos e indígenas, bem como daqueles que tenham cursado integralmente o ensino médio em escolas públicas, às instituições de educação superior.

Art. $8^{\underline{0}}$ As instituições de que trata o art. $1^{\underline{0}}$ desta Lei deverão implementar, no mínimo, $25 \%$ (vinte e cinco por cento) da reserva de vagas prevista nesta Lei, a cada ano, e terão o prazo máximo de 4 (quatro) anos, a partir da data de sua publicação, para o cumprimento integral do disposto nesta Lei.

Art. 9ํㅡㄹ Esta Lei entra em vigor na data de sua publicação.

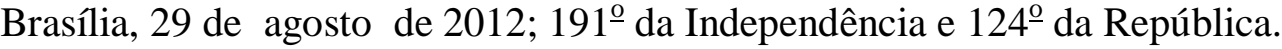

DILMA ROUSSEFF

Aloizio Mercadante

Miriam Belchior

Luís Inácio Lucena Adams

Luiza Helena de Bairros

Gilberto Carvalho 


\section{ANEXO C}

\section{F F C L R P INIVERSIDADE DE SÃO PAULO-USP}

- - Faculdade de Filosofia, Ciências e Letras de Ribeirão Preto. Departamento de Educação, Informação e Comunicação

Mestrado em Educação - Campus de Ribeirão Preto

Pesquisa: “ARGUMENTAÇÃO EM PRODUÇÕES TEXTUAIS DO ENSINO MÉDIO SOBRE AS COTAS RACIAIS EM UNIVERSIDADES PÚBLICAS BRASILEIRAS”

Mestranda em Educação na USP: Dayane Pereira Batista- dayanebatista@usp.br

\section{Objetivos:}

$\checkmark$ Apresentar a proposta da pesquisa "Argumentação em produções textuais do Ensino Médio sobre as cotas raciais em universidades públicas brasileiras";

$\checkmark$ Ler (e discutir) dois textos sobre a temática: "cotas raciais";

$\checkmark$ Entregar os termos de consentimento aos alunos e aos pais;

$\checkmark$ Elaborar do texto dissertativo-argumentativo.

\section{Apresentação temática:}

- Universidades públicas brasileiras: USP, UNICAMP, UNESP, UFSCar e UFTM.

- Instituições de ensino particulares: PUC, UNAERP, Moura Lacerda, Barão de Mauá e UNIESP.

- Vestibular, PROUni, FIES, ENEM e SiSU.

As políticas afirmativas visam ao: "[...] incremento da contratação e promoção de membros de grupos discriminados no emprego e na educação por via de metas, cotas, bônus ou fundos de estímulo; bolsas de estudo; empréstimos e preferência em contratos públicos; determinação de metas ou cotas mínimas de participação na mídia, na política e outros âmbitos; reparações financeiras; distribuição de terras e habitação; medidas de proteção a estilos de vida ameaçados; e políticas de valorização identitária" (GEMAA, 2011, p. 4).

Assim, "a implantação de políticas de ação afirmativa deve ser acompanhada por uma ampla discussão [...]" (LOPES, 2003, p. 87).

\section{Reflexão preliminar:}

$\mathrm{O}$ que você pensa sobre as cotas direcionadas para afrodescendentes em universidades públicas brasileiras para que eles entrem nesses locais? 


\section{ANEXO D}

\section{Coletânea}

\section{$\underline{\text { Cotas raciais }}$}

Leia atentamente o texto 1 e o texto 2, pois eles trazem informações relevantes e posicionamentos diferentes a respeito das cotas direcionadas à população negra brasileira.

Texto 1

\section{Argumentos a favor das cotas}

\section{A reserva de vagas dá oportunidade dos menos favorecidos frequentarem instituições de qualidade.}

Publicado por Letícia de Oliveira Januário

Mais da metade dos brasileiros se declararam negros, pardos ou indígenas no último Censo do Instituto Brasileiro de Geografia e Estatística (IBGE), realizado em 2010. Mesmo com este percentual, não é fácil encontrar por aí negros e pardos vivendo em situação igualitária com brancos. Uma das medidas que busca introduzir e diminuir a desigualdade entre brancos e negros no país é a chamada Lei das Cotas.

A Lei $\mathrm{n}^{\mathrm{o}} 12.711$ foi aprovada em 2012, o que representa que a partir desta data todas as instituições de ensino superior federais do país precisam obrigatoriamente reservar parte de suas vagas para alunos oriundos de escolas públicas, de baixa renda, e negros, pardos e índios. A reserva começou em $12,5 \%$ e precisa chegar aos $50 \%$ até 2016.

Segundo o professor de Cultura Brasileira Marcos Minuzzi, doutor pela Pontifícia Universidade Católica do Rio Grande do Sul (PUCRS), essas medidas são importantes para mostrar que há uma preocupação sobre a intensa desigualdade no país. "Tenho opinião favorável, no sentido de que democratiza o acesso, considerando nossas grandes desigualdades sociais. Pode-se criticar o sistema ou tentar encontrar outras formas de democratização de acesso mais eficazes, mas o importante é que os mecanismos existentes refletem uma preocupação de resolver o problema”.

Além da dívida histórica que o país tem com os afrodescendentes por anos de exploração, a lei veio para minimizar as diferenças raciais e socioeconômicas que sempre existiram no Brasil. Aqui, somente 47,73\% dos brasileiros se declaram brancos, segundo o Censo de 2010, tornando se assim um dos países mais miscigenados do mundo. Mesmo com toda essa mistura ainda há diferenças que gritam aos nossos olhos.

As cotas sociais representam os motivos de sua própria existência. $\mathrm{O}$ abismo existente entre escolas públicas e particulares fornecem, claramente, oportunidades distintas a estudantes de classes sociais diferentes. Sem as cotas para os estudantes de 
classes sociais menos favorecidas, as cadeiras nas melhores universidades continuarão sendo conquistadas por candidatos com melhor estabilidade financeira. O ideal seria qualificar o ensino público, mas isso levaria décadas.

A Universidade de Brasília (UnB) foi a primeira instituição federal a aprovar cotas para minorias étnicas e raciais e a primeira instituição brasileira a aprovar cotas exclusivamente para negros. De 2004 até o 2013, 18,5\% dos estudantes que se formaram pela universidade são negros e ingressaram na instituição graças ao sistema.

No Brasil, negros e pardos representam $52 \%$ da população, mas nas instituições federais esse índice cai para $40 \%$, sendo $32 \%$ de pardos e apenas $8 \%$ negros, segundo estudo feito pela Associação Nacional dos Dirigentes das Instituições Federais de Ensino Superior (Andifes), em 2011. Com a política de cotas a expectativa é que dentro de alguns anos este panorama mude e haja maior inclusão dos menos favorecidos na sociedade.

Disponível em: <http://vestibular.mundoeducacao.com/cotas/argumentos-favor-dascotas.htm.R7TV>Acesso em: 01 jun. 2015. 
ANEXO E

\section{$\underline{O \text { grande erro das cotas }}$}

\section{A partir de agora, uma em cada duas vagas nas universidades federais estará reservada para egressos do ensino público, negros, índios e pardos. É uma forma equivocada de corrigir distorções}

A presidente Dilma Rousseff sancionou uma lei aprovada pelo Congresso que vai mudar radicalmente o ensino público superior no Brasil - e não necessariamente para melhor. Uma em cada duas vagas nas universidades federais passará a ser preenchida por critérios que desprezam o mérito.

Alunos que cursaram o ensino médio em escolas públicas terão direito a 120 mil das 240 mil vagas disponíveis nas federais. Esse número será distribuído segundo a cor da pele ou a autodeclarada etnia do candidato. Pretos, pardos e índios, não importa o seu desempenho escolar, passam a ter lugar garantido nos bancos das universidades na proporção da população verificada pelo Censo do IBGE em cada Estado. Metade dessa cota vai para estudantes vindos de famílias de baixa renda.

O Brasil tem hoje 2341 instituições de ensino superior, públicas e privadas. Desse total, apenas 59 serão afetadas pela Lei de Cotas - além das federais, o projeto inclui alguns cursos técnicos de ensino médio e profissionalizantes ligados ao Ministério da Educação.

Em termos absolutos, é bem pouco. Ocorre que, juntamente com as universidades públicas estaduais, as universidades federais são as mais importantes usinas de descobertas científicas, conhecimento e pesquisa do Brasil. Vêm delas, por exemplo, $86 \%$ dos artigos científicos publicados internacionalmente, segundo dados recentes. Das dez instituições que mais emitiram pedido de patente entre 2004 e 2008, quatro delas eram universidades públicas - duas federais e duas estaduais. Nenhuma particular entrou no ranking. Isso só é possível porque é para elas que conflui a elite cultural, acadêmica, intelectual - e, sim, quase sempre econômica também do país.

Agora, a Lei de Cotas poderá desviar esse curso. Em vez de ir para os alunos mais preparados, quase sempre egressos de escolas particulares, metade das vagas caberá aos menos preparados, vindos do deficiente ensino público.

A Lei de Cotas, tal como foi enviada para a sanção de Dilma Rousseff, não é ruim apenas porque põe em risco a produção de conhecimento no país e atropela a meritocracia. Ela é ruim também porque mascara e força a perpetuação de um dos problemas mais graves da educação no Brasil: a péssima qualidade das escolas públicas do ensino médio e fundamental. "Se tivéssemos um ensino básico decente, esses alunos conseguiriam competir de igual para igual com os alunos das particulares. Mas é claro que é mais fácil criar cotas do que investir na base", afirma o economista Claudio de Moura Castro, especialista em educação e articulista de VEJA.

Trecho do post publicado originalmente em 4 de setembro de 2012 (Adaptado da reportagem de Julia Carvalho, publicada em edição impressa de VEJA para a coluna de Ricardo Setti) 18/11/2014 às 20:36

Disponível em: <http://veja.abril.com.br/blog/ricardo-setti/politica-cia/o-grande-errodas-cotas-nas-universidades/> Acesso em: 01 jun. 2015 


\section{ANEXO F}

\section{Propostas de redação:}

Escola A:

Redija uma dissertação argumentativa em prosa (o texto não deve ser escrito em forma de poema ou narração) sobre o tema: "As cotas raciais em universidades públicas brasileiras".

Ao desenvolver o tema proposto, procure utilizar os conhecimentos adquiridos e as reflexões feitas ao longo de sua formação. Selecione, organize e relacione argumentos, fatos e opiniões. Procure argumentar de modo a deixar claro seu ponto de vista sobre o assunto.

Lembre-se: a redação deve obedecer à norma-padrão da língua portuguesa. Escreva, no mínimo, 07 e, no máximo, 25 linhas, com letra legível. Utilize caneta azul ou preta. Dê um título ao seu texto.

\section{Escola B:}

Redija uma dissertação argumentativa em prosa (o texto não deve ser escrito em forma de poema ou narração) sobre o tema: "As cotas raciais em universidades públicas brasileiras".

Ao desenvolver o tema proposto, procure utilizar os conhecimentos adquiridos e as reflexões feitas ao longo de sua formação. Selecione, organize e relacione argumentos, fatos e opiniões. Procure argumentar de modo a deixar claro seu ponto de vista sobre o assunto.

\section{INSTRUÇÕES:}

- O texto definitivo deve ser escrito à tinta, na folha própria, em até 30 linhas.

- Escolha um título para o seu texto.

- A redação que apresentar cópia dos textos da Proposta de Redação terá o número de linhas copiadas desconsiderado para efeito de correção.

\section{A REDAÇÃO RECEBERÁ NOTA ZERO SE:}

- Tiver até 7 (sete) linhas escritas, sendo considerada "insuficiente";

- Fugir ao tema ou não atender ao tipo dissertativo-argumentativo;

- Apresentar proposta de intervenção que desrespeite os direitos humanos;

Apresentar parte do texto deliberadamente desconectada com o tema proposto. 